\title{
Mud Volcano and Its Evolution
}

\author{
Bambang P. Istadi $1{ }^{*}$, Handoko T. Wibowo ${ }^{2}$, Edy Sunardi ${ }^{3}$, \\ Soffian Hadi ${ }^{4}$ and Nurrochmat Sawolo ${ }^{1}$ \\ ${ }^{1}$ Energi Mega Persada \\ ${ }^{2}$ Independent geologist \\ ${ }^{3}$ Universitas Padjajaran \\ ${ }^{4}$ Sidoarjo Mudflow Mitigation Agency \\ Indonesia
}

\section{Introduction}

The term mud volcano refers to topographical expressions of naturally occurring volcanoshaped cone formations created by geologically excreted liquefied sediments and clay-sized fragments, liquids and gases. Ejected materials often are a mud slurry of fine solids suspended in liquids which may include water and hydrocarbon fluids. The bulk of released gases are methane, with some carbon dioxide and nitrogen. Mud volcanoes may be formed by a pressurized mud diapir which breaches the Earth's surface or ocean bottom. Flowing temperatures at the ocean bottom may be as low as freezing point and are associated with the formation of hydrocarbon hydrate deposits. Flowing temperatures can also be hot if associated with volcanic gases and heat escaping from deep magma which can turn groundwater into a hot acidic mixture that chemically changes rock into mud and clay-sized fragments. These mud volcanoes are built by a mixture of hot water and fine sediment that either pours gently from a vent in the ground like a fluid lava flow; or is violently ejected into the air as a lava fountain of escaping mud, volcanic gas, stream and boiling water.

Mud volcanoes are most abundant in areas with rapid sedimentation rates, active compressional tectonics, and the generation of hydrocarbons at depth. Typically they are also found in tectonic subduction zones, accretionary wedges, passive margins within deltaic systems and in active hydrothermal areas, collisional tectonic areas, convergent orogenic belts and active fault systems, fault-related folds, and anticline axes. These structures act as preferential pathways for deep formation fluids to reach the surface. (see Pitt and Hutchinson, 1982, Higgins and Saunders, 1974; Guliyiev and Feizullayev, 1998; Milkov, 2000; Dimitrov, 2002; Kopf, 2002, Mazzini, 2009).

The existence of mud volcanoes are controlled by tectonic activity where fluid escapes from areas undergoing complex crustal deformation as a result of transpressional and transtensional tectonics. Collisional plate interactions create abnormal pressure condition and consequently overpressured buildup of deep sedimentary sediment which in turn result in formation of diapirs. Over pressured zones typically are under-compacted sedimentary layers which have lower density than the overlying rock units, and hence have an ability to

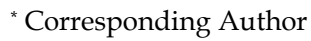


flow. They are the product of rapid deposition where the connate water is trapped, unable to escape as the surrounding rock compacts under the lithostatic pressure caused by overlying sedimentary layers. In thick, rapidly deposited shale dominant sedimentary sequence, the low and reduced porosity and permeability due to compaction inhibit the expulsion of water out of the shale. As burial continues, fluid pressure increases in response to the increasing weight of the overburden. This Non-equilibrium compaction is believed to be the dominant mechanism in formation of overpressured sediments. Over pressure however can also result from maturing organic rich predominantly clay sediments which are generating methane and other heavier gases that are still trapped within the sedimentary sequences. The above geological elements that result in diapirsm and mud volcano is often known as "elisional" basin mainly characterized by rapid deposition of thick young sediments, presence of abnormally high formation pressure or overpressures fluids, under-compacted sediments, petroleum generation, compressional setting, high seismicity and occurrence of faults (see Milkov, 2000, and Kholodov, 1983).

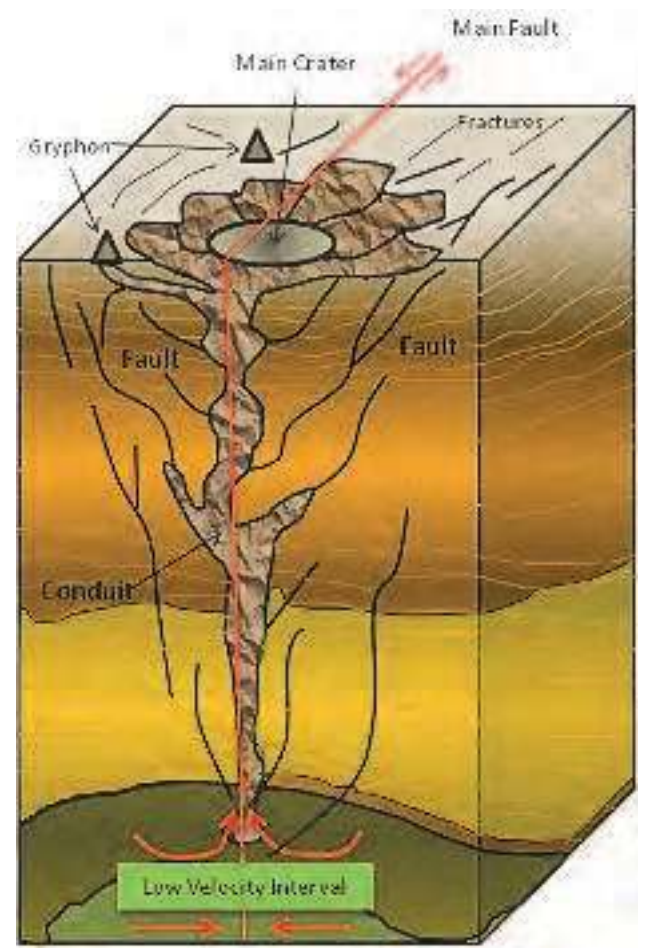

Fig. 1. Basic structure and anatomy of a conical mud volcano. The mud volcano is formed by the escaping natural gas that rises to the surface when it finds a conduit (strike slip fault) and carries mud which has a lower density (and typically found as low velocity interval) than the surrounding sedimentary succession. Fluid, gas, and surface water are ejected in a cone shape like a mountain and forms craters, mud pools (salses) and cones (gryphons). Tectonic movement is very influential, as well as rapidly deposited sediments and burial of organic rich sediments. Strike-slip faults in active tectonic regions are the most ideal place for the formation of mud volcanoes. 
Overpressure buildup mechanisms contribute to the brecciation of the deep sedimentary units include for example the dewatering of thick clay-rich sedimentary units, and geochemical reactions in sedimentary units with high temperature gradients are the mechanism for the eruption (Mazzini, 2009). He further suggest that when the subsurface overpressure reaches a threshold depth where the overburden weight is exceeded, fracturing and breaching of the uppermost units occur, sometimes facilitated by external factors such as earthquakes. The upward movement of the mud to surface is due to buoyancy and differential pressure.

Geological structures like faults and anticlines where mud volcanoes are commonly found are easily perturbed by earthquakes as they represent weak regions for the seismic wave's propagation. This mechanism is well described by Miller et al. (2004) where earthquakes initiating local fluid movements cause fractures that propagate to the surface manifesting with a time delay from the main earthquake. Miller et al. (2004) propose a link between earthquakes, aftershocks, crust/mantle degassing and earthquake-triggered large-scale fluid flow where trapped, high-pressure fluids are released through propagation of coseismic events in the damaged zones created by the mainshock. The resulting disturbance of the gravitational instability triggers the beginning of flow, while the pressure drops and the lower cohesion media is easily fluidized and ultimately vacuumed to the surface through piercement structures which provide the conduits for high pressure mud/fluid and gas release.

The geometry of mud volcanoes is variable. They can be up to a few kilometers in diameter and several hundred meters in height. The main morphological elements of a mud volcano are the crater(s), hummocky periphery mud flows, irregularly shaped terrains, gryphons, and mud lakes or salses. A classification of mud volcanic edifices morphology was proposed by Kholodov, 2002 (in Akhmanov and Mazzini, 2007), these are: (1) "classic" conic volcanic edifice with main crater and mud flow stratification reflecting periodical eruption; (2) Stiff mud neck protrusion, typically due to its high viscosity and hence able to form steep hills; (3) swamp-like area; contrary to no (2), due to its low viscosity the mud spreads over a large area; (4) "collapsed synclinal" depression; and (5) crater muddy lake, is the most abundant type in various mud volcanic areas. It is often that mud volcano morphology shows a combination of the common types described above depending on the viscosity of the mud and the stage of its development.

Mud volcanoes show different cyclic phases of activity, including catastrophic events and periods of relative quiescence characterized by moderate activity. It appears that each eruptive mud volcano has its own period of catastrophic activity, and this period is variable from one volcano to another. The frequency of the eruptions seems essentially controlled by local pressure regime within the sedimentary sequences, while the eruptive mechanism and evolution seem strongly dependent on the state of consolidation and gas content of the finegrained sediments. This is shown in the compilation of historical data onshore Trinidad as described by Deville and Guerlais (2009).

Approximately 1,100 mud volcanoes have been identified on land, in shallow as well as deep waters. It has been estimated that well over 10,000 may exist on continental slopes and abyssal plains. The largest known structures are $10 \mathrm{~km}$ in diameter and reach $700 \mathrm{~m}$ in height. Occurrences of mud volcanoes on the seafloor have been documented more frequently since the intensive use of side scan sonar began in the late 1960's. Mud volcanoes have been found in many parts of the world, and have been documented in Rumania, Italy, Iran, Iraq, New Zealand, India, the Myanmar, Malaysia, Gulf of Mexico, Trinidad, 
Venezuela, Colombia and the USSR. The largest number of mud volcanoes is found in the Azerbaijan trend which continues into the Southern Caspian area. In the Indonesian region, mud volcanoes are found on the Islands of Sumatera, Nias, Pagai, Sipora, East Java, East Kalimantan '(Borneo), Rote, Barbar, Aru, Timor, Tanimbar, Yamdena and Papua. They are found in high rate subsidence basins such as Madura-East Java Basin, Kutai Basin, in high seismicity areas such as islands in the Banda Sea and in tectonically complex areas such as Timor and Papua (Sukarna, 2007).

In Papua, Indonesia, mud volcanoes are found along a zone of disruption $400 \mathrm{~km}$ long and nearly $100 \mathrm{~km}$ wide, occupying hilly terrain with low relief scarred by landslip. They are aligned along structural trends of up to $50 \mathrm{~km}$ long and $25 \mathrm{~km}$ wide. Individual mud volcanoes range from $3 \mathrm{~m}$ to $2.5 \mathrm{~km}$ in diameter and reach a maximum height of about 110 $\mathrm{m}$. The ejected mud consist of mud stone containing various shapes and sizes of clasts of older rock assumed as exotic block, which is believed as part of mélange diapirsm (Sukarna, 2007).

Information on mud volcanoes can be used to study the subsurface condition and used as pathfinders of the conditions indicative of subsurface hydrocarbon accumulations in unexplored areas. Gas geochemical data from mud volcanoes can be examined for possible presence of source rocks and their maturity levels. Mud volcanoes are often related to active petroleum systems, especially if the released gas shows a deep thermogenic character. A global data-set of more than 140 onshore mud volcanoes from 12 countries shows that in $76 \%$ of cases the gas is thermogenic, with $20 \%$ mixed and only $4 \%$ purely microbial (Etiope et al., 2009). The thermogenic nature of most of mud volcanoes is related to the relatively high thermal maturity of gas-generating organic-rich rocks. On the other hand, mud volcanoes which release large amounts of $\mathrm{CO}_{2}$, such as those related to magmatic activity, may not indicate the presence of significant hydrocarbon reservoirs (e.g., Milkov, 2005). Many large onshore hydrocarbon fields were discovered after drilling around mud volcanoes in Europe, the Caspian Basin, Asia and the Caribbean (see Etiope et al, 2009, Link, 1952; Guliyev and Feyzullayev, 1997). Gas origin, composition and secondary post-genetic processes such as secondary methanogenesis which follows anaerobic biodegradation of petroleum or heavy hydrocarbons however, are fundamental factors for determining depth and quality of the related petroleum system, especially in frontier or unexplored areas (see Etiope et al., 2009).

Apart from providing information and evidence of hydrocarbon potential and a working petroleum system, mud volcanoes also provide useful data about the sedimentary section which can be determined by examination of ejected rock fragments incorporated in mud volcano sediments (breccia).

Mud volcanoes, depending on their size and activity, can pose ecological hazards and disaster to the environment as well as to the population of the surrounding area. Mud volcanoes typically ejected breccia and/or mud flows and/or flame in temporal association with earthquakes. Active mud volcanoes can vent a large amount of carbon dioxide and flammable methane, and may influence global climate. Large eruptions are known to have occurred in the Black Sea and in areas around the Caspian Sea where gas exploded in a flame several hundred meters high that burns vegetation within the vicinity of the mud volcano. Mud volcanoes may also pose a geohazard for drilling and platform constructions due to the potentially violent release of large amounts of hydrocarbons and mud breccia. When the viscosity of the mud breccias is low, it may flood large area and inundate villages, homes, roads, rice fields, and factories and displace people from their homes. 


\section{Evolution of LUSI Mud volcano}

Kusumadinata, 1980 described mud volcanoes as any extrusion on the earth's surface in the form of clay or mud in which morphology forms a cone in which there is a lake and coupled with the discharge of water and is driven by strong gas flow. Often the release of gas is followed by an explosion and burns, thus the extrusion appearance greatly resembles a magmatic volcano. Apart from this description, Sangiran dome (e.g. Watanabe and Kadar, 1985) and 1936 Dutch maps (see Duyfjes, 1936), very little has been published in journals and scientific papers on mud volcanoes in Western Indonesia, unlike the ones found in Eastern Indonesia such as in Timor (e.g. Barber et al., 1986). In fact, mud volcanism in Indonesia, particularly in East Java is poorly understood. This lack of understanding changed when the LUSI mud volcano (Lumpur "mud"- Sidoarjo), was born as it offered a unique opportunity to study the dynamic development of a mud volcano from its birth on 29th May 2006. In contrast, studies on mud volcanism are typically conducted during the dormant periods between eruptions of already existing mud volcanoes.

The subsequent eruption of LUSI mud volcano has been closely observed and analyzed by the geological community (see Mazzini et al., 2007, 2009; Sunardi et al, 2007; Kadar et al., 2007; Sudarman and Hendrasto, 2007; Kumai and Yamamoto, 2007; Hutasoit, L, 2007; Sumintadireja et al., 2007; Deguchi et al, 2007; Abidin et al. 2007, 2008; Satyana, 2007, 2008; Satyana and Asnidar, 2008; Fukushima, 2009; Mori and Kano, 2009; Hochstein and Sudarman, 2010; Sutaningsih, 2010 etc). Its birth occurred just 2 days after a devastating Yogyakarta earthquake in May 2006. The trigger of LUSI mud volcano is controversial, and has been the center of debate among geoscientists and drilling engineers as it is located near the Banjarpanji-1 oil and gas exploration well drilling that was being drilled. (i.e. Mazzini et al., 2007; Davies et al., 2007, 2008; Manga, 2007; Manga et al., 2009; Tingay et al., 2008, 2010; Sawolo et al., 2008, 2009, 2010; Istadi et al., 2008, 2009). Mazzini proposed that LUSI was caused by fracturing following the May $27^{\text {th }}$ earthquake and accompanied depressurization of $>100{ }^{\circ} \mathrm{C}$ pore fluids from $>1700 \mathrm{~m}$ depth. This resulted in the formation of a quasihydrothermal system with a geyser-like surface expression and with an activity influenced by the regional seismicity. Davies, on the other hand, suggested that an underground blowout in the Banjarpanji-1 well breached to the surface, thus creating a conduit for the high pressured fluid to escape and created a mud volcano.

The LUSI mud volcano eruption has continued for over five years, and potentially will continue for many years to come, impacting an ever larger area. The mud eruptions occurred in at least five separate locations forming a NNE-SSW lineament about $200 \mathrm{~m}$ away from the Banjarpanji-1 (BJP-1) exploration well in Sidoarjo, approximately $30 \mathrm{~km}$ south of Surabaya, East Java, Indonesia (Fig. 2 \& 8). The approximately $700 \mathrm{~m}$ lineament is contiguous with the Watukosek fault zone (Istadi et al., 2009).

Hot mud erupted at 5,000 $\mathrm{m}^{3}$ a day at the beginning, increased to $50,000 \mathrm{~m}^{3} /$ day in the initial months, then escalated to $125,000 \mathrm{~m}^{3}$ / day and reached a high rate of $156,000 \mathrm{~m}^{3}$ /day by October 2006. The high flow rates coincide with a series of earthquakes. In less than one year after its birth, LUSI displaced some 24,000 people, inundated toll road, several villages, housing estates, paddy fields and farm land, factories, schools, mosques, shops, offices, destroyed a gas pipeline, killing 13 workers and has covered about $700 \mathrm{Ha}$ of land. The extent of the damage caused by LUSI is substantial and has caused subsidence of up to 5.53 $\mathrm{cm} /$ day in the area next to the main eruption. Simulation shows that it will affect an area of $3 \mathrm{~km}$ radius, disrupt the subsurface condition and subsidence of up to 60 meters. In a highly 
populated area of Sidoarjo, this could potentially disrupt more than 10,000 families; a major issue to the people, infrastructures and environment. The eruption rate however, has decreased to less than $10,000 \mathrm{~m}^{3}$ /day at the time of writing in July 2011; perhaps LUSI is now entering a new phase, from an eruptive one to a mature and quiescence phase.

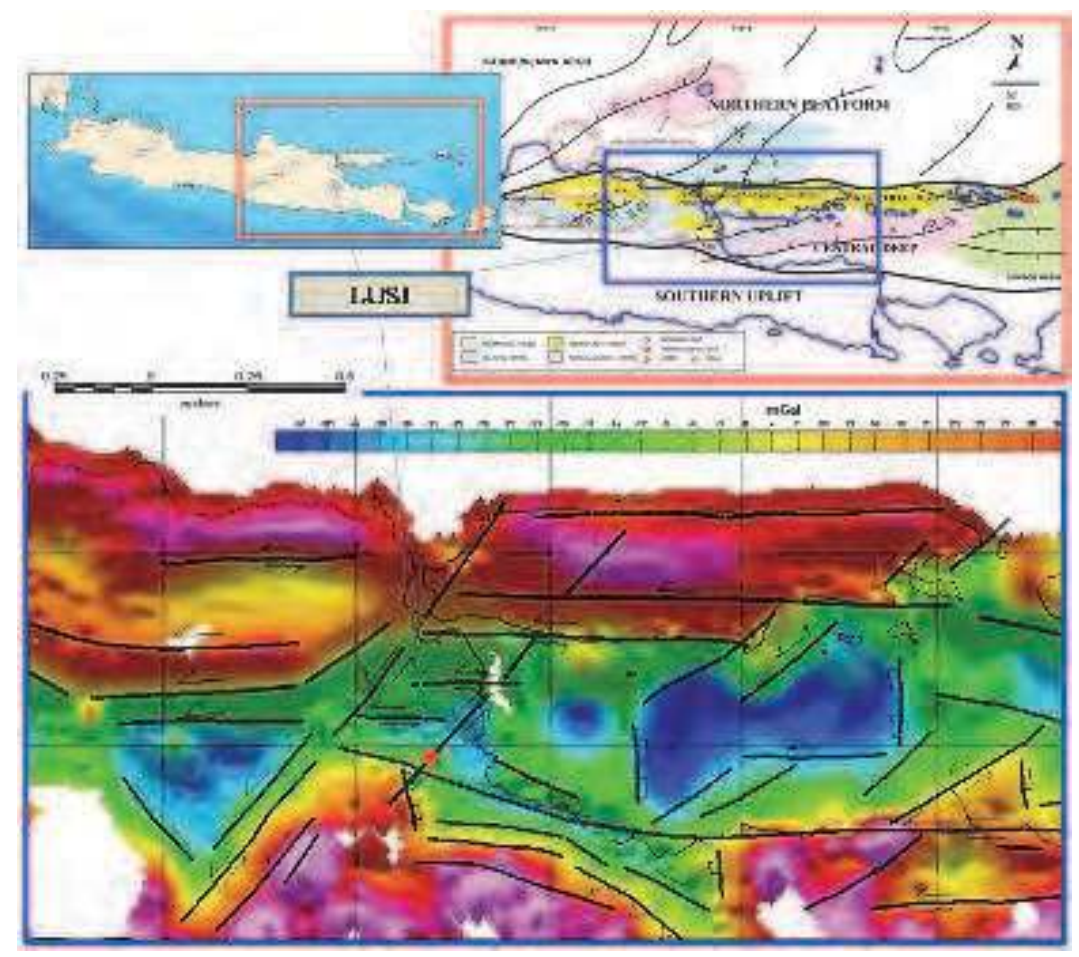

Fig. 2. LUSI is located in East Java, about $30 \mathrm{~km}$ South of Surabaya (top left). Regional tectonic framework of East Java (top right) shows major NE-SW and E-W major fault trends. Bouguer Gravity map (processed with $2.65 \mathrm{~g} / \mathrm{cc}$ density) of East Java (bottom) showing East Java Basin's depositional centers (blue) which are controlled by the major faults in the area.

\subsection{Stratigraphic setting of the LUSI Mud volcano}

The LUSI Mud Volcano is located about $10 \mathrm{~km}$ northeast of Penanggungan Mountain, in Reno Kenongo village, Porong District, Sidoarjo Regency, East Java. Its location is in the Southern part of the hydrocarbon prolific East Java inverted back-arc Basin which was formed during the Oligocene- Early Miocene (Sribudiyani et al, 2003), on the Eastern tip of the Kendeng Zone (De Genevraye and Samuel,1972). The Geology of the area is characterized by the rapid deposition of thick organic rich sediment as part of the Brantas delta, influenced by the extensional tectonic regime (Willumsen and Schiller, 1994, Schiller et al, 1994). Due to the rapid deposition, shales in the area are undercompacted and overpressured (Mazzini et al., 2007). The geological condition is similar to other areas where mud volcanoes are found such as the Caspian and the Black Sea (Planke et al, 2004, Mazzini et al., 2007; Tingay et al., 2008) 
Java Island, located at the southern part of the Sundaland, was formed by rock assemblages associated with an active margin of plate convergence. The island has recorded plate convergence between the Australian plate and the Sundaland continental fragment since Late Cretaceous. Therefore, the island is made up of complex of plutonic-volcanic arcs, accretionary prisms, subduction zones, and related sedimentary rocks (Satyana and Armandita, 2004). The structural history is divided into two phases: a Middle Eocene to Oligocene extensional phase, and a Neogene compressional or inversion phase. Grabens and half-graben structures were developed during the extensional phase, which was followed in the Neogene by compressional deformation with some wrenching. The most recent sedimentation in the East Java Basin occurred during the Late Pliocene to Holocene (3.6-0 $\mathrm{Ma})$, during which time the southern part of the basin (Kendeng depression zone) was affected by north verging thrusts and uplift. The depression developed as a response to the isostatic compensation of the uplift of the southern Oligo-Miocene volcanic arcs. The uplift was accompanied by an influx of volcaniclastic rocks from the southern volcanic arc provenance and were deposited into the depression and causing the depression to subside. Other provenance of the Kendeng Depression is the northern uplifted area that filled the basin with shallow-marine carbonates and marine muds from the Oligocene to the Holocene. Very thick sediments from the two provenances were deposited rapidly into the Kendeng Depression mostly as turbiditic deposits. The East Java geosyncline has thick Tertiary sediments of more than $6000 \mathrm{~m}$ (Koesoemadinata, 1980) with an estimated sedimentation rate of $2480 \mathrm{~m} / \mathrm{ma}$ in the vicinity of LUSI (Kadar et al.,1997). The high sedimentation rates followed by rapid subsidence caused non-equilibrium compaction, and along with the maturation of organic materials resulted in the overpressured sediments within the Kendeng zone (see Willumsen and Schiller, 1994; Schiller et al., 1994). The overpressured sediments were later compressed, become mud diapirs and pierced the overlying sediments in many parts of East Java as mud volcanoes.

Outcrops of sedimentary rocks are very rare as they are covered by alluvial sediements and weathering. Therefore fresh rock outcrops at the rock mine in Karanggandang Village, 28 $\mathrm{km}$ to the northwest of the LUSI (Kadar et al, 2007) is important to complete the stratigraphic column of LUSI and the Banjarpanji-1 well.

The stratigraphy at LUSI (figure 3) consists of (1) alluvial sediments, (2) Pleistocene alternating sandstone and shale of the Pucangan Formation (to about $500 \mathrm{~m}$ depth), (3) Pleistocene clay of the Pucangan Formation (to about $1000 \mathrm{~m}$ depth), (4) Pleistocene bluish gray clay of the Upper Kalibeng Formation (to $1871 \mathrm{~m}$ depth), and (5) Late Pliocene volcaniclastic sand of at least $962 \mathrm{~m}$ thickness. The stratigraphy below the Late Pliocene sand is not well known; however, when the Banjarpanji-1 well reached $2834 \mathrm{~m}$ depth, cuttings from the bottom of the well did not contain limestone fragments indicating that drilling of Banjarpanji-1 well had not reached the carbonate reservoir target. Davies et al. (2007) suggested that these porous rocks were Kujung Formation limestone and that this formation is the source of the fluids erupting at LUSI. Seismic correlations from the Porong1 well, $6.5 \mathrm{~km}$ to the northeast of LUSI, indicate that the rocks underlying the Late Pliocene volcaniclastic sands are carbonates which contain coralline red algae fossils, corals and foraminifera fragments. The strontium isotope (Sr) of the carbonates shows the absolute age of 16-18 ma Early Miocene, and therefore the carbonates are correlated with the Tuban Formation outcrops found extensively in the western part of East Java basin which show age range from $15.2 \mathrm{ma}$ to $20.8 \mathrm{ma}$ based on analysis of strontium isotopes (Sharaf et al., 2005). 


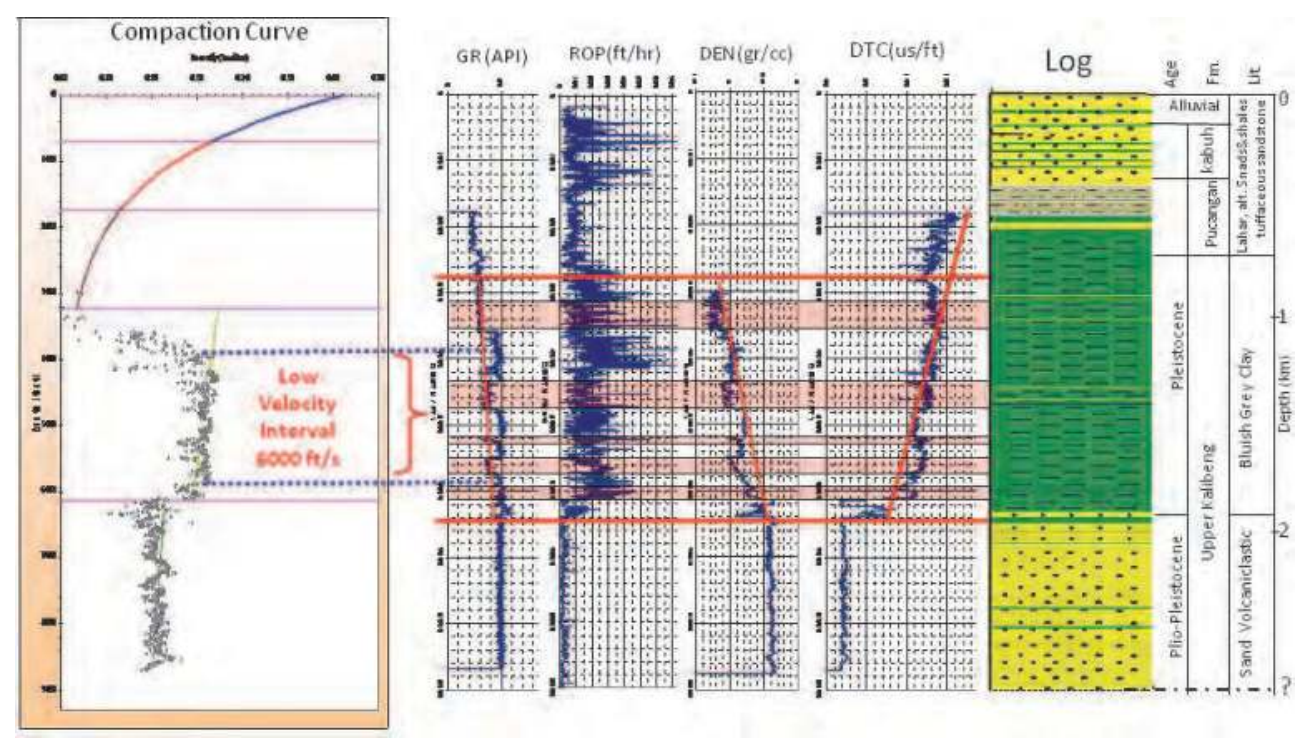

Fig. 3. Stratigraphy column in BJP \#1 well nearby LUSI MV. Density, GR, ROP and DT suggest the presence of overpressured zones. These are probably highly plastic, undercompacted shale, controlled by rapid sedimentation that trapped water and resulted in an overpressured condition.

The seismic cross-section of this trajectory (figure 4) has a path through three wells, and track from SW to ENE. The wells are Banjarpanji-1 (BJP-1), Tanggulangin-1 (TGA-1) and Porong-1 (PRG-1). At the bottom of the well of Banjarpanji-1 well is a mass of shale that appears mounded and has a large structural dimension. Faulting in the form of positive flower structure between the wrench faults that continuously cut the low velocity intervals, is interpreted as a mud diapir (a depth> $9292 \mathrm{ft}$ or $2834 \mathrm{~m}$ ).

The structural feature that resembles a flower structure suggests the presence of a wrench fault, thus horizontally sliding components and oblique movements are suggested. The presence of overpressured zones probably consists of highly plastic, undercompacted shale. On seismic it is correlated with a Low velocity zone, and it is characterized by a chaotic discontinues pattern.

The collapse structure adjacent to the well Porong-1, located approximately $7 \mathrm{~km}$ from LUSI forms a depression around the crater. This structure likely represents an extinct mud volcano that, once it terminated its activity, gradually collapsed around a vertical feeder channel. The multiple contemporaneous faults indicated in the seismic section is due to gravitational slumps and intrusive structure suggesting piercement from the upward moving over-pressured sediments of the underlying shale diapir are evident (see Istadi, 2009). By the same mechanism, the multiple faults at LUSI may have been reactivated and served as conduit for the mud eruptions along the fault planes. 


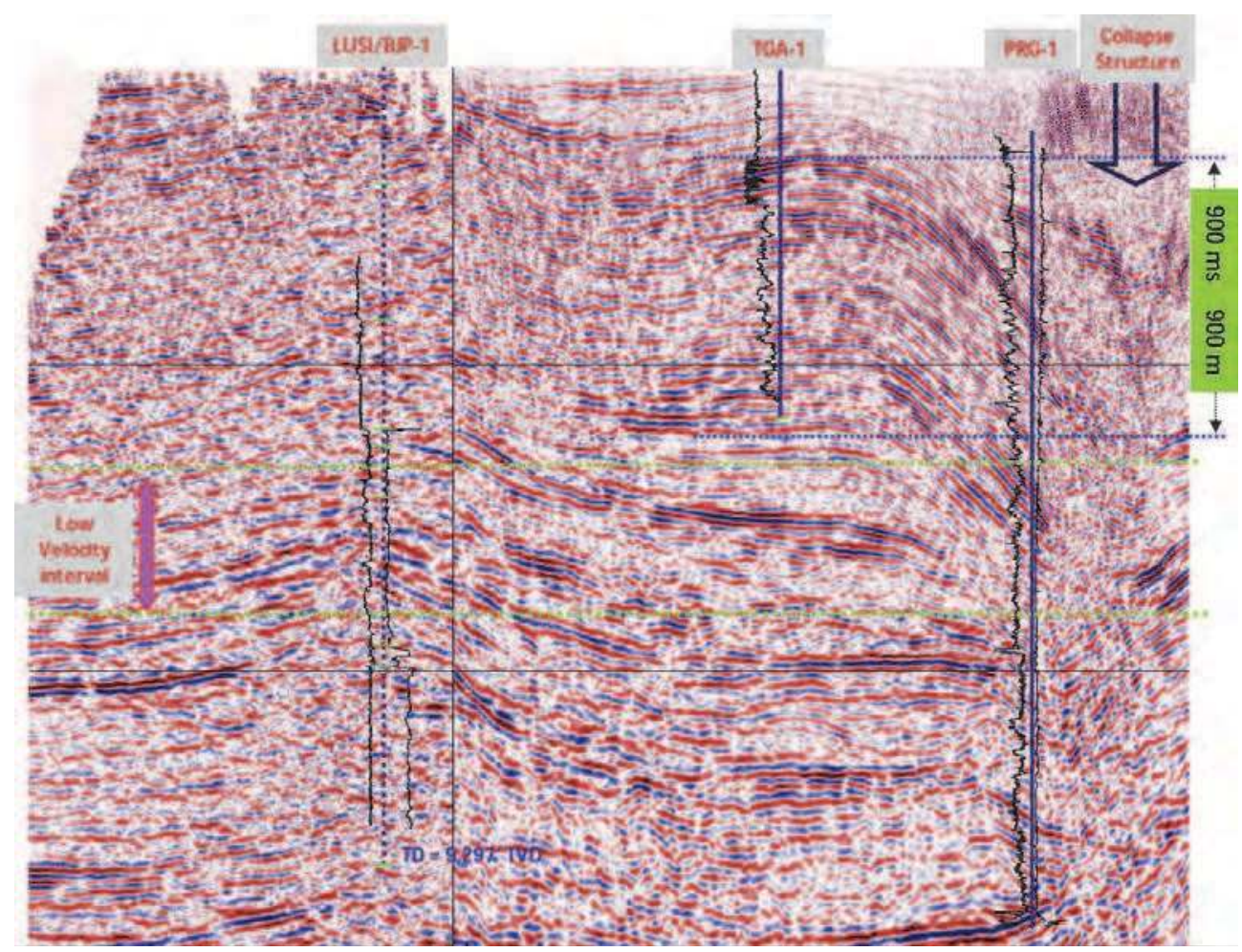

Fig. 4. Seismic section of LUSI - Banjarpanji-1 - Tanggulangin-1 - Porong-1 - Porong collapse structure. The Porong collapse structure located approximately $7 \mathrm{~km}$ from LUSI is a paleo mud volcano where subsidence is evident and the multiple faults present likely served as conduits for the mudflow. Similarly, the multiple faults near the BJP-1 well (200 m from LUSI) may have been reactivated and served as conduit for the mud eruptions and escaping gas, hence the appearance of gas bubbles along fault lines.

\subsection{Controversy on the trigger}

The trigger of the LUSI mud volcano is controversial because of its location and time of birth. The insinuating factors include:

1. The surface location of LUSI is approximately 200 meters away from an exploration well, the Banjarpanji well (Davies et al., 2007, 2008 and 2009). This suggests a possible connection between the drilling of the well and LUSI.

2. A major 6.4 Richter scale magnitude Yogyakarta earthquake rocked Java Island two days earlier (Mazzini et al., 2007 and 2009). This may have reactivated local fault and allowed an overpressured mud to escape to the surface.

3. The exploration well suffered two major drilling problems after the earthquake; two mud losses following the earthquake and a kick during the drill string removal (Sawolo et al., 2009 and 2010). This suggests a possible link between the earthquake and the change in the subsurface condition of the region. 
4. A number of mud volcanoes in the vicinity of Watukosek fault were reported to suddenly become active at the time of the earthquake (Mazzini et al., 2009)

5. Three mud eruptions that appeared to be in line with the direction of Watukosek Fault (Sawolo et al., 2009)

6. The limited amount of well data available in the public domain especially on the events prior and following the initial eruptions as well as discrepancies over the interpretation of drilling data from the Banjarpanji-1 well (Tingay, M., 2010).

The process of LUSI mud volcano creation is generally believed to be a natural process of an over pressured shale eruption through seismically reactivated faults as conduits (Mazzini et al., 2009). The trigger of the eruption, however, is still a hotly debated issue within the engineering community. Was the creation triggered by a reactivation of nearby Watukosek fault or an underground blowout in Banjarpanji well? A well blowout generally means an uncontrolled flow of formation fluid into a wellbore that travelled up the well to the wellhead. An underground blowout, on the other hand, is when the flow of reservoir fluid does not exit at the wellhead but flows to a low pressured formation in the well and eventually breaches the surface.

Banjarpanji-1 is an exploration well that was drilled in March 2006 in a densely populated part of East Java, in the Sidoarjo region. In May 2006, the well was drilling toward its target, the Kujung limestone. There was little subsurface drilling problems during the drilling process as the well was drilled using a Synthetic Oil Based mud that eliminated much of the problems in the thick overpressured shale section. The schematic of the well is shown in figure 5 .

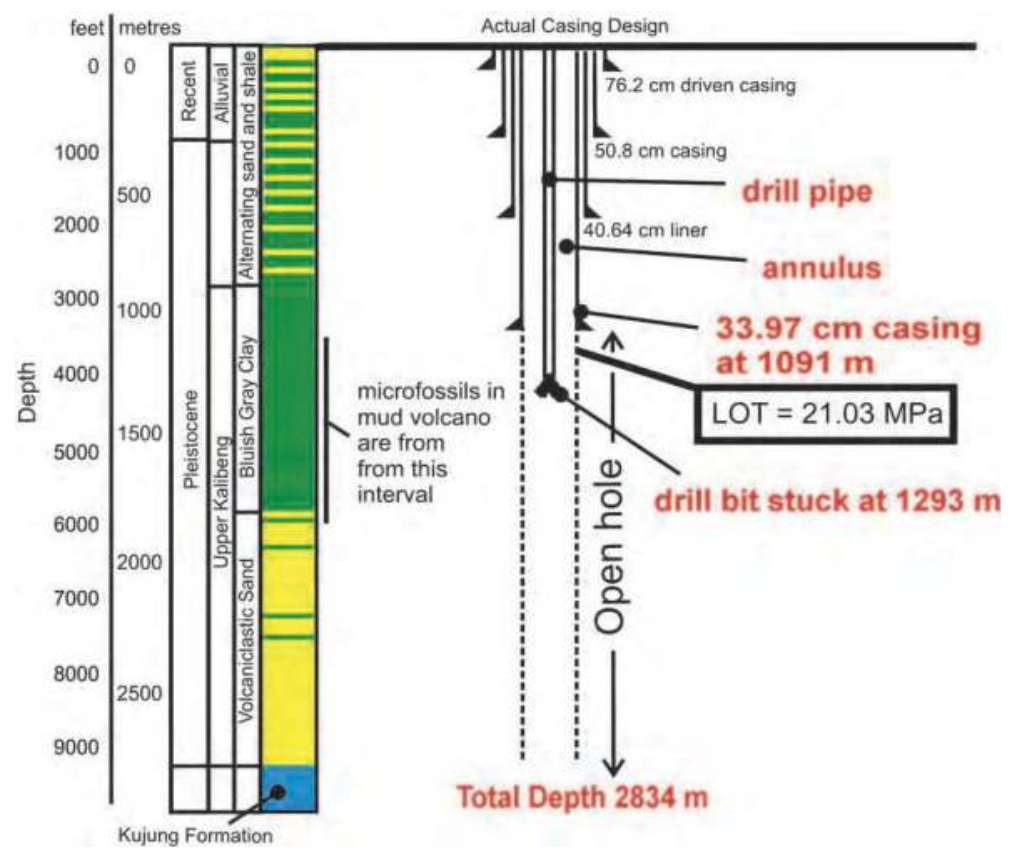

Fig. 5. Summary of the stratigraphy drilled by the Banjarpanji-1 well and the casing setting depths (Davies et al.,2008). 
The problem free drilling condition changed in May 27th 2006 when a 6.4 magnitude earthquake strike near Yogyakarta about $250 \mathrm{~km}$ away. Within ten minutes of the earthquake, a 20 bbls of mud loss was observed in the well. Another mud loss occurred following two major aftershocks of 4.8 and 4.6 magnitude where a 130 bbls of drilling mud was lost to the open hole. Drilling mud loss is a serious problem in drilling as the mud hydrostatic pressure is the only mechanism to balance the reservoir pore pressure. Such major mud losses typically occur when drilling mud flows into a newly drilled cavity or a fractured zone or newly formed fractures.

\subsection{The underground blowout hypothesis}

An underground blowout is not an uncommon problem during well drilling, especially in exploration wells where the geology and reservoir pore pressure is uncertain. If the effective mud weight used to drill the well falls below the pore pressure, a kick (an influx of formation fluid into the well bore) can happen. This kick displaces the heavy drilling mud which reduces the hydrostatic pressure of the mud column and causes an even larger influx of formation fluid. This kick must be killed correctly and a proper hydrostatic pressure restored in order to retain the control of pressure in the well. If the kick is not controlled properly and the well is subjected to a pressure above its critical fracture pressure, then the weakest formation, generally immediately below the casing shoe, may fracture. When there is sufficient force behind the kick, this fracture can propagate upward into shallower formations, or even breach to the surface. This is the mechanism of an underground blowout during drilling of a well.

The possibility that the mud eruption was caused by an underground blowout in the Banjarpanji-1 well was initially suggested by the media immediately after the eruption. There was very little official information of its cause and very little well data was available in the public domain at the time. A similar charge was later iterated in the Davies et al., 2007 and 2008 papers with a pressure analysis that suggested a fracture at the casing shoe. Davies proposed that the well was subjected to a pressure above its critical fracture pressure that caused its weakest formation to fracture. The hydro-fracturing of the formation was propagated and finally it breached to the surface and caused LUSI.

In his papers, Davies proposed a number of operational sequences during the drilling of the Banjarpanji-1 well that caused a kick that leads to the underground blowout. Originally he proposed that the over pressured Kujung limestone was drilled, and this provided the high pressure fluid that caused a kick in the well (Davies et al., 2007). In his later paper (Davies et al., 2008), Davies refined his proposition to the kick was caused by a pressure under-balance in the well since 46 stands of drill pipe were removed without replacing the lost volume due to the removal of the drill pipes. And in his latest discussion paper (Davies et al., 2009) he proposes that the kick was due to a 'swabbing' effect. Swabbing means a negative pressure due to an upward movement of drill string.

Davies propositions of Underground Blowout hypothesis is rejected as pressure inside the well is too low to break the formation at the casing shoe of the Banjarpanji-1 well (Nawangsidi, D., 2007). The assumption used by Davies to develop his hypothesis is incorrect as the well is not full of mud but contains water as well as gas; this in effect lower the specific gravity and the hydrostatic pressure in the well. With a lower specific gravity and the published annulus pressure cited by Davies, it is impossible to fracture the casing shoe.

Davies's postulations on what happened, are not supported by well data and the actual condition of Banjarpanji-1 well (Sawolo et al., 2009). In his paper, Sawolo showed that (i) the 
Kujung carbonate was not penetrated by the well, as the calcimetry data during drilling remained low - suggesting that no carbonate formation is drilled, and the well experienced a loss of mud (the opposite of a kick). (ii) The charge that mud was not pumped to compensate for the pulling of drill string out is incorrect. Automatic data recorder showed that mud was pumped appropriately to compensate for the pulling of the drill string. (iii) Analysis on speed when pulling out of the hole and the condition of the wellbore preclude the possibility of swabbing. And finally, (iv) pressure analysis based on the automatic data recorder (Real Time Data-RTD) showed that the pressure exerted on the casing shoe is too low to be able to fracture the formation. It is therefore concluded that the well was intact, no underground blowout occurred in the well and the Banjarpanji well could not have been the trigger of LUSI.

The geologists and drillers in charge of drilling the well have reviewed all the data and cannot support the underground blowout theory. They charge that it is an over simplification to the actual condition (Sawolo et al., 2010). Their approach in analyzing the trigger of LUSI was broader than that of Davies. Instead of relying on limited data and assumptions to fill the missing gap, they collected all available drilling data, logs and cross checked it with other reports to come up with an enriched credible set of data. The various data were assembled to form a mosaic that clearly showed that the well remained intact and an underground blowout in the Banjarpanji-1 well did not occur.

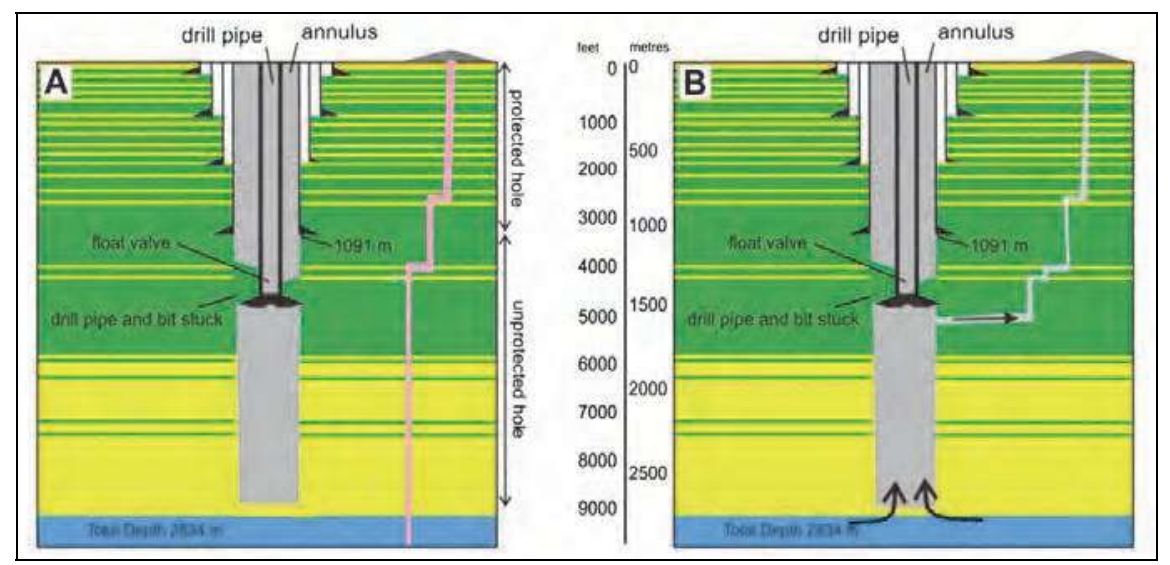

Fig. 6. The controversy on LUSI's trigger; Sawolo's view (A) - where the well is intact, the mud flow did not pass through the well. Davies (B), contends that the mud passed through the well, fracturing the casing shoe and triggered the LUSI mud volcano (Sawolo et al., 2010).

The geologists believe that LUSI is more likely to be related to seismic activity. The loss of drilling mud that coincided with the time of the earthquake suggests that the earthquake may have altered the subsurface condition of the region.

The two opposing views of the LUSI trigger as a seismic related event (Sawolo et al) and an underground blowout (Davies et al.,) are shown in figure 6. The scenario proposed by Sawolo is shown in A, where the well is intact and the mud flow did not pass through the well. Davies view is shown in B, where the mud flow passed through the well and fractured the casing shoe.

The root cause of the difference of opinion between Davies and Sawolo is believed to be access to well information; especially the quality and quantity of data used in the pressure 
analysis. Analysis based on limited data can result in a misleading conclusion. It should be understood that the well information on the public domain at the initial stages of the eruption was limited as majority of data was kept confidential by the oil and gas company. It was not until 2009 that Sawolo et al. published for the first time a wide range of well data and observations previously not available in the public domain; this includes important data on formation strength such as the Leak Off Test, Bottom Hole Pressure, minute by minute well pressures and fluid density in the well. The intent of opening the data to the scientific community was that future research on LUSI could be based on actual and credible data in order to minimize assumptions.

The engineering debate on the trigger of LUSI continued until 2010, when Tingay, 2010 published a paper outlining the pros and cons of the competing theories. The paper presented the first balanced overview of the LUSI mud volcano by identifying critical uncertainties of the plumbing system, events prior and following the initial eruptions as well as discrepancies over interpretation of petroleum engineering data from the Banjarpanji-1 well. These uncertainties caused much of the trigger controversy. It is obvious that more studies are needed before LUSI's actual trigger can be identified.

\subsection{The fault reactivation hypothesis}

Mud volcanoes are spatially associated with both major and secondary faults within the regional stress field. Surface and subsurface geology shows that faults exist in the region that crosses LUSI areas with the NE-SW and NW-SE direction trends. Faulting in the NE-SW direction is known as the Watukosek fault, an oblique strike-slip fault, whereas the NW-SE trend dextral strike-slip fault pattern is the Siring fault. These faults are partly buried by alluvial sediments.

Eruption of mud volcanoes along the fault line is one of several possible subsurface hydrological responses to earthquakes. Manga, however, dismissed the possibility that LUSI was triggered by the Yogyakarta earthquake that occurred two days earlier because of its distance and magnitude (Manga, M. 2007). An empirical plot from past earthquakes in the world shows a distinct relation between the earthquake's magnitudes to the distances from their epicentres (figure 9).

When the data-point from the Yogyakarta 27th May 2006 earthquake was entered, it shows that the Yogyakarta earthquake was unlikely to have caused the LUSI mud volcano. It is interesting to note that two past earthquakes that were larger and closer to the area failed to cause a mud volcano in the region.

Mellors has a similar view on the relationship between large earthquakes and triggering effect on mud volcanoes (Mellors et al., 2006). This is because large earthquakes produce strong static and dynamic stress changes near its centre that could trigger mud volcanoes. His research is based mainly on a 191 years record of mud volcano eruption and large earthquake in the Caspian Sea. It suggests that the triggering effect is strongest where the shock at the mud volcano has the intensity of approximately Mercalli 6 and above and at a distance of less than $100 \mathrm{~km}$. However, he also found that even when the intensities exceed the apparent threshold, only a fraction of active volcanoes erupt. This indicates that other factors also play an important role.

However, there are too many uncertainties in predicting the triggering effect of earthquakes on mud volcanoes (Mori and Kano, 2009). Mori pointed out that until recently, seismologists would not believe that triggering due to earthquakes over hundreds of kilometres is 

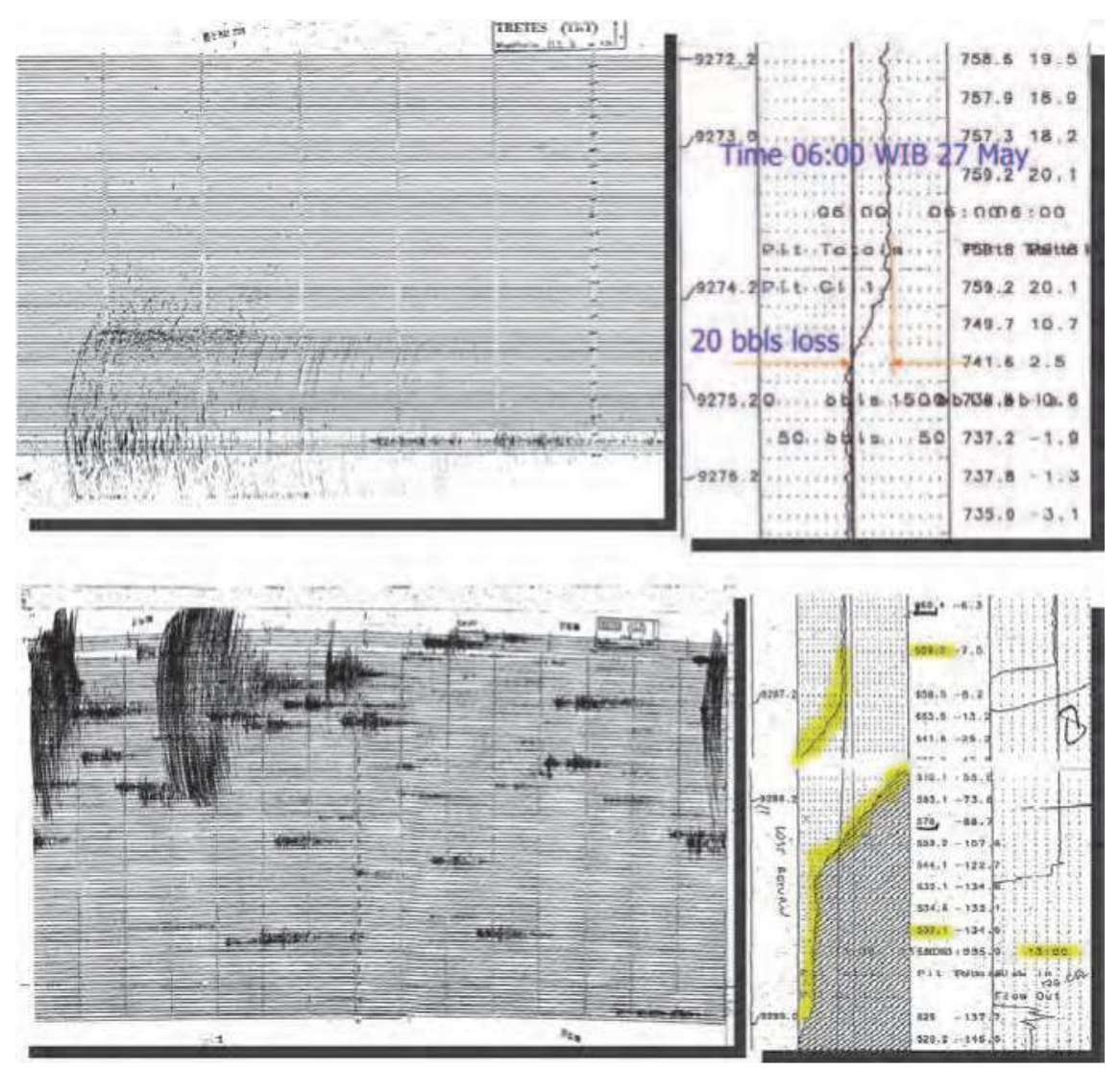

Fig. 7. Losses of mud after the Yogyakarta earthquake. The top left picture shows the seismograph reading at Tretes BMG station about $15 \mathrm{~km}$ away and the right picture shows the 20 bbls loss seven minutes after the main earthquake. The bottom left showed the aftershocks and the right shows the 130 bbls complete loss of circulation from the wellbore that happened two hours after two aftershocks (Sawolo et al., 2009).

possible. This view has changed especially in the hydrothermal areas. When Mori entered the Yogyakarta earthquake and LUSI data in Fisher's Dynamic Stress vs. Frequency plot (figure 10), it is located within the value that has triggered mud volcanoes in other regions.

Mazzini, one of the very few earth-scientists who conducts field work and data measurement right after the mud eruption, also disagrees with Manga's conclusion (Mazzini et al., 2007). He cited that eruptions can be affected by earthquakes several thousands of kilometres away and that a delay of few days between the time of the earthquakes and the eruption is not uncommon.

His field work showed that a regional fault, the strike-slip Watukosek fault, crosses The LUSI area. A number of extinct mud volcanoes are found aligned with this fault from Java to Madura island. In addition, seismic profiles acquired prior to the eruption shows evidence of a vertical piercement structure with upwards dipping strata around the LUSI conduit zone. He argued that this could be interpreted as evidence for a long history of 


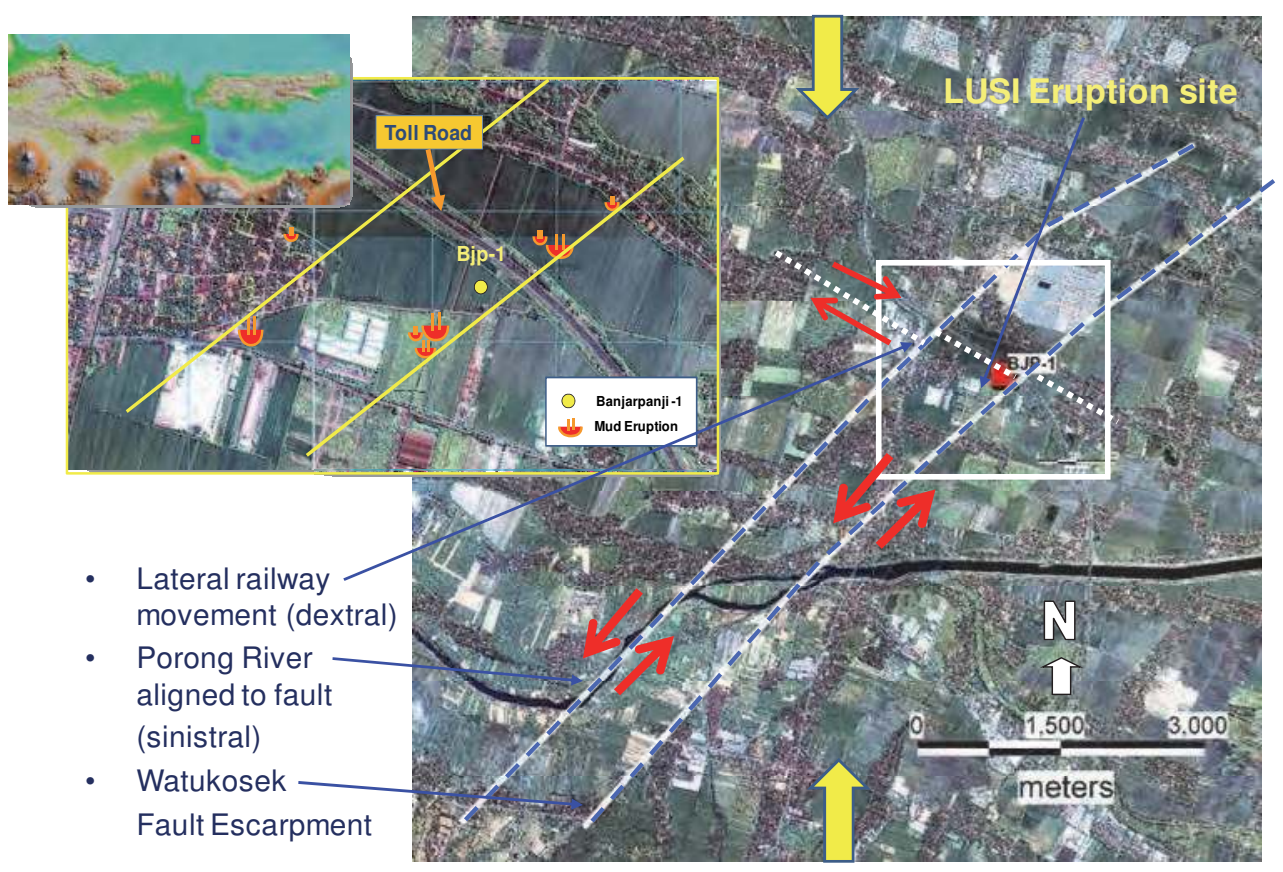

Fig. 8. Watukosek fault, consisting of 2 parallel faults where the Porong River is aligned along the fault line, while the Watukosek fault escarpment represents the up thrown fault block. LUSI eruption sites are along the Watukosek fault line. The Watukosek fault, striking from the Arjuno volcanic complex, crosses the LUSI mud volcano and extends towards the northeast of Java island.

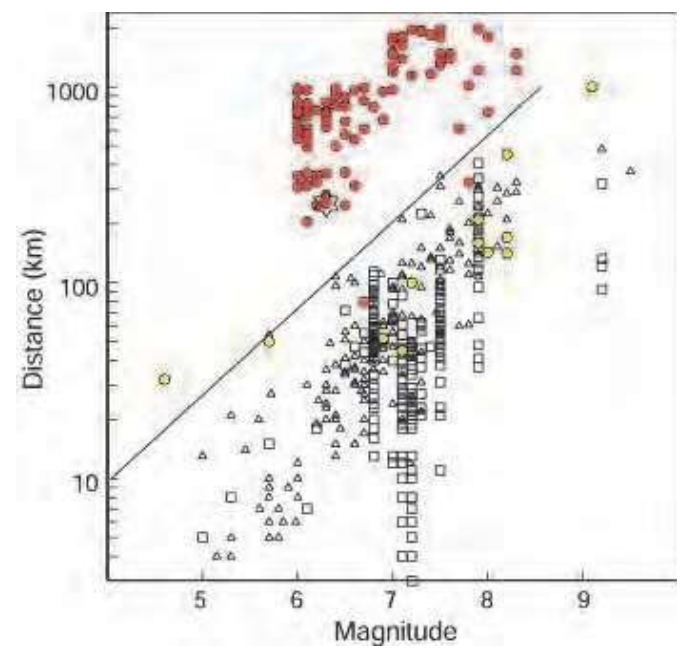

Fig. 9. Distance between the earthquake epicenter and hydrologic response as a function of earthquake magnitude (Manga, M., 2007). 


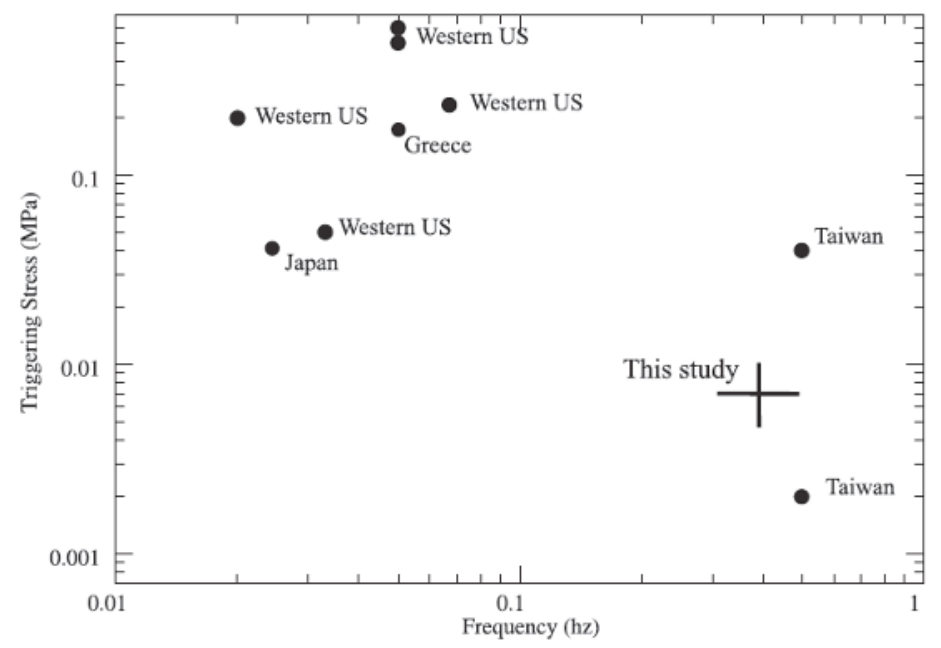

Fig. 10. Values for dynamic stress and frequency of seismic waves that have triggered small seismic events, compiled by Fisher et al. (2008). The cross shows the estimate for the Yogyakarta earthquake at LUSI. Source: Mori and Kano, 2009

active vertical movements of mud underneath LUSI, possibly with former eruptions or as a disturbed signal due to the fault that crosses this area. He suggested that the Yogyakarta earthquake ultimately triggered the eruption through the already overpressured subsurface piercement structure. This is supported by a partial loss of well fluid recorded in the Banjarpanji well nearby 10 minutes after the earthquake, and a major loss of well fluid after two major aftershocks (see previous chapter on The Underground Blowout Hypothesis figure 7). These mud losses, he argued, could be the result of movements along the fault that was reactivated, lost its sealing capacity and become the passageways for overpressured subsurface fluid to escape. These fluids ultimately reached the surface at several locations aligned NE-SW in the Watukosek fault zone direction.

Davies disagreed with Mazzini's conclusion that the Yogyakarta earthquake reactivated the Watukosek fault and triggered LUSI mud volcano (Davies et al., 2007). He argued that the earthquake was too small and too distant to trigger an eruption when in the recent past, two bigger and closer earthquakes failed to trigger an eruption. He considered the static and dynamic stresses caused by the magnitude 6.4 earthquake too small to trigger LUSI.

Mazzini backed his hypothesis by presenting further field data that support his hypothesis that a strike-slip faulting was the trigger mechanism that released overpressure fluids through already present piercement structures (Mazzini et al., 2009). He presented several observations on the fault reactivation evidence, among others:

- Residents close to the Gunung Anyar, Pulungan, and the Kalang Anyar mud volcanoes, located along the Watukosek fault almost $40 \mathrm{~km}$ NE of LUSI (Fig. 1), reported increased venting activity of the mud volcanoes after the Yogyakarta seismic event. Simultaneously, boiling mud suddenly started to erupt in Sidoarjo, later forming the LUSI mud volcano.

- A $1200 \mathrm{~m}$ long alignment of several erupting craters formed during the early stages of the LUSI eruption. The direction of these aligned craters coincides with the Watukosek 
fault. The craters were formed during May-early June 2006, but were later covered by the main LUSI mud flows.

- Large fractures several tens of centimetres wide and hundreds of meters long were observed in the proximity of the BJP-1 exploration well with identical NE-SW orientation. However no fluids were observed rising through these fractures, which suggests a shear movement rather than a deformation from focussed fluid flow.

The intersection of the fault with the nearby railway clearly indicates lateral movement. The observed lateral movement recorded at the railway during the first four months was $40-50 \mathrm{~cm}$. The lateral movement recorded at the neighbouring GPS stations during the same time interval reveals at total displacement of $22 \mathrm{~cm}(2 \mathrm{~cm}$ in July, $10 \mathrm{~cm}$ in August, $10 \mathrm{~cm}$ in September) (see figure 11). This later displacement was possibly related to the gradual collapse of the LUSI structure. In any case, the difference between these two records shows that an initial $15-20 \mathrm{~cm}$ of displacement that must have occurred during the early stages (i.e. end of May-June) related to the Watukosek fault shearing. Since $27^{\text {th }}$ May earthquake, the rails have had to be repaired four times. Two of these repairs were done within the first three months after the earthquake to remove the bending due to the continuous shearing.
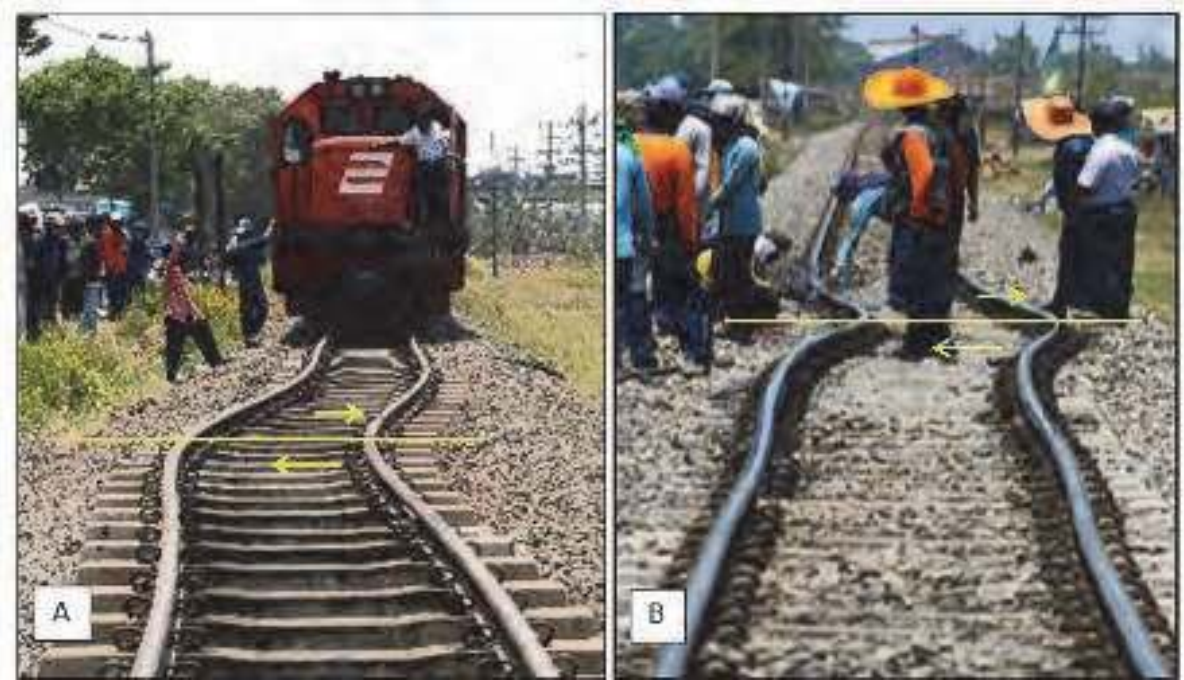

Fig. 11. Shear stress have damaged nearby infrastructures such as the dextral movements of a railway, bursting of a gas pipeline and numerous breakages of water pipelines at the same location further supports displacements along faults. (A)The railway bent to the west of main vent on September 2006. Offsets that occurred approximately $40 \mathrm{~cm}$ with orientation direction NW - SE. (B) At the same location, the railway was bent again in October 2009, with an offset of approximately $45 \mathrm{~cm}$. The bending of the railway line is due to fault reactivation that often has differential movements which created shear stress.

- A water pipeline experienced significant bending and ruptures at the intersection with the fault (Fig. 5A-B). Since the May 2006 earthquake occurred, the pipeline has been repaired sixteen times. Note that neither the rails nor the water pipeline had kink problems before the earthquake. 
He also found seismic sections taken in the 1980s that showed a dome-shaped piercement structure; the most spectacular is the collapse structure in the nearby Porong 1 well (Istadi et al., 2009) (see figure 4). This structure is likely to represent an extinct mud volcano that gradually collapsed around its own vertical feeder channel.

Mazzini further showed shear-induced fluidization mechanism through experiment that a relatively small displacement resembling a fault movement can turn a pressurized sand box model from once sealing layers, to become non-sealing. He demonstrated that the critical fluid pressure required to induce sediment deformation and fluidization is dramatically reduced when strike-slip faulting is active. (see Mazzini et al., 2009).

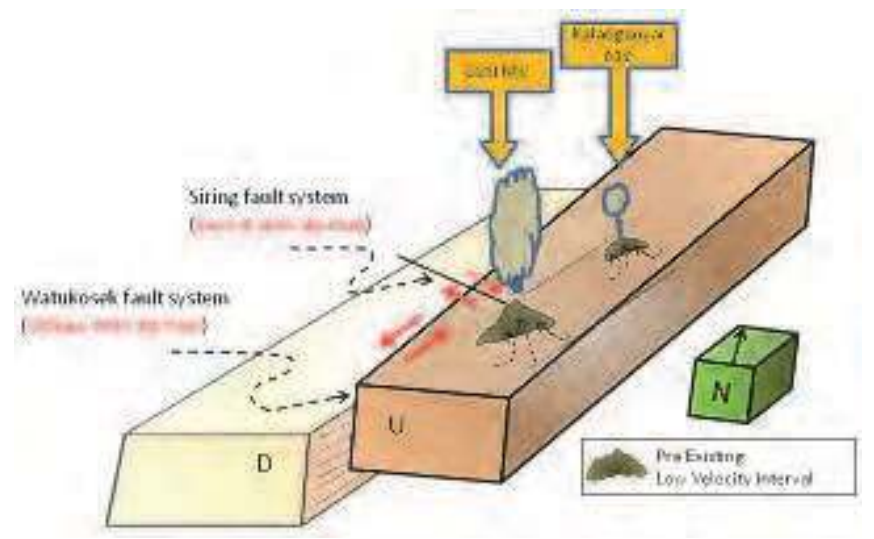

Fig. 12. Schematic cartoon (not to scale) of a mud volcano appearing along strike-slip faults. The shear zone along the Watukosek fault system and Siring fault that crosses LUSI where a low velocity interval existed before the eruption. Reactivation of the strike-slip fault after the earthquake caused the draining of fluids from the low density units towards the fault zone as the preferential pathway.

\subsection{Response to earthquake}

Due to its tectonic position at the front of the subducting Australian plate under the Sunda plate to the south, Java has been seismically active (see figure 13A). The compressional stresses, either due to subduction or its secondary effect that compresses the Sunda plate in a N-S direction, puts strain on local faults, especially those trending NE-SW. The latter caused a rupture on the NE-SW Opak fault, and had resulted in the magnitude 6.4 Yogyakarta earthquake, on 27 May 2006. This earthquake led to a new understanding of its effect on the volcanic plumbing system of Java Island. At the time of the earthquake, two Javanese volcanoes - Merapi and Semeru, were active; the distance of these volcanoes from the epicenter are around $50 \mathrm{~km}$ and $260 \mathrm{~km}$ respectively (see figure 13). It was observed that while there was no new volcanic eruption, the eruptive response of the heat and volume flux of these two volcanoes changed considerably by a factor of two-to-three starting on the third day after the earthquake (Harris and Ripepe, 2007). Their work revealed immediate eruptive response through processing of thermal data for volcanic hot spots detected by the Moderate Resolution Imaging Spectrometer (MODIS), (http://hotspot.higp.hawaii.edu). This implies that the earthquake triggered enhanced simultaneous output and identical trends in heat and volume flux at both volcanoes. 

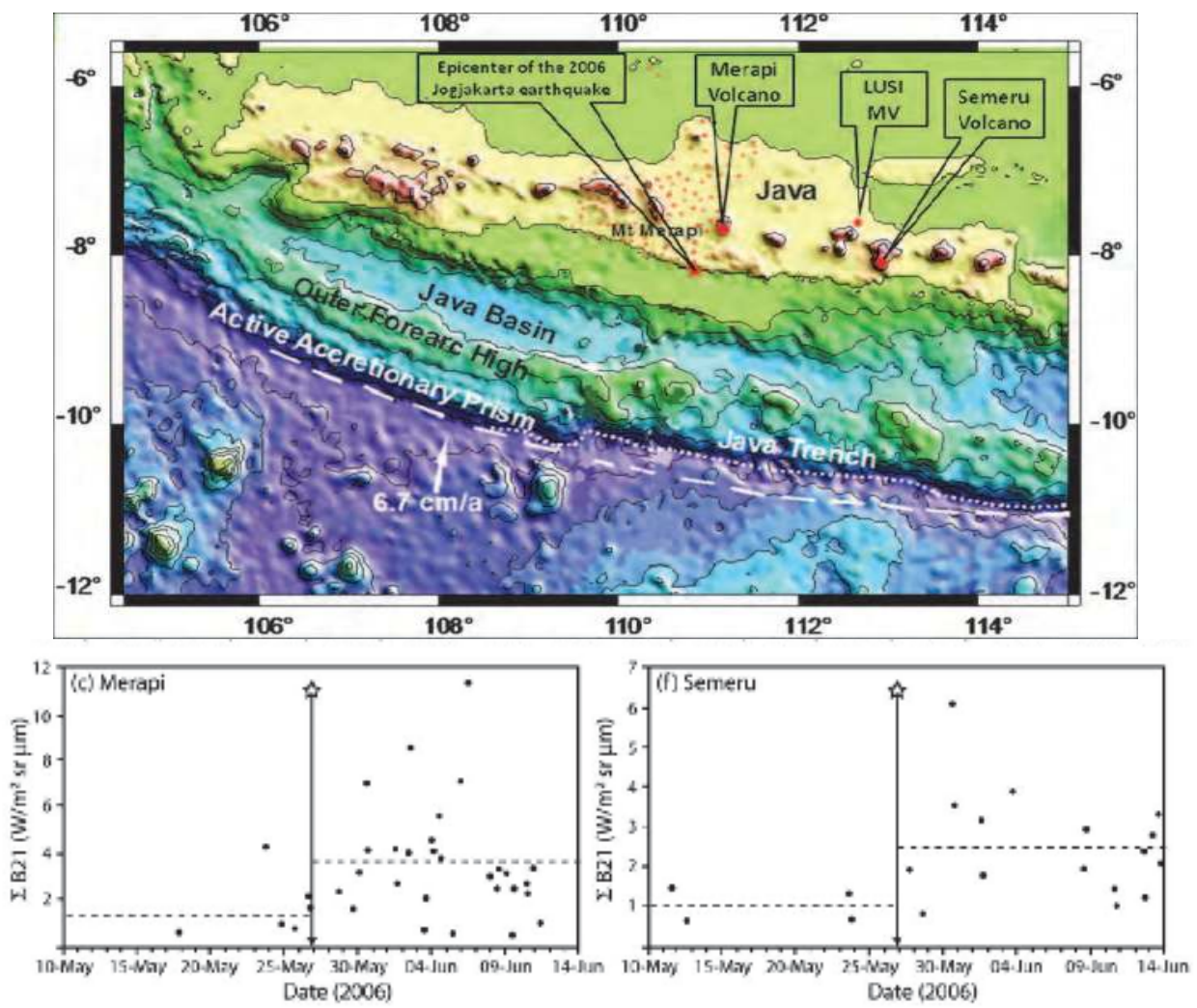

Fig. 13. Map of Java, showing the location of the Merapi and Semeru volcanoes. Increases in heat and volume flux occured 3 days after the Yogyakarta earthquake in the Merapi and Semeru Volcanoes. Thermally anomalous pixels detected by MODVOLC showing all band 21 pixel radiance. Source: Harris and Ripepe, 2007.

It was also reported that the magma extrusion rate and the number of pyroclastic flows from the volcano suddenly tripled [Walter et al., 2008]. This change did not last long, and everything was back to normal again after 12 days. This observation suggests that while this magnitude 6.4 earthquake may not able to trigger a new eruption, it is able to change the intensity of an erupting volcano at a long distance $(260 \mathrm{~km})$.

The May 2006 earthquake was one of the deadliest earthquakes in Java in historical times. Although it was as a magnitude 6.4, the scale of destruction was unprecedented in the region. The large scale destruction was concentrated in a $10-20 \mathrm{~km}$ distance along the Opak River Fault where the subsurface lithology consists mainly of soft volcaniclastic lahar deposit (Walters et al., 2007). Walters study suggests that such deposits have the property to amplify the ground motion such that even a relatively small magnitude earthquake could result in large scale destruction.

The two works of Harris and Ripepe, and Walters suggest the complex interdependency of the causes and effects in a seismically and volcanically active environment. The $27^{\text {th }}$ May 
2006 earthquake changed the static and/or dynamic stresses of the area. Their studies suggest a link between earthquake, changes in subsurface condition and its effect on the volcanic activity.

To monitor and record seismic waves around LUSI seismograph installation was carried out at several stations between April and July 2008 (see Figure 14). Seismic waves can be generated by the existing fault activity or by new cracks in the rock layers that had lost their cohesive strength as a result of subsidence around the main eruption vent of LUSI. The microseismic or seismic waves and energy released during crack formation in the rocks is relatively small compared to the energy released by earthquakes.

Microseismic activity recorded by the seismograph network installed around LUSI consists of 6 sensor units, of short period type and broadband seismographs. Each seismograph was
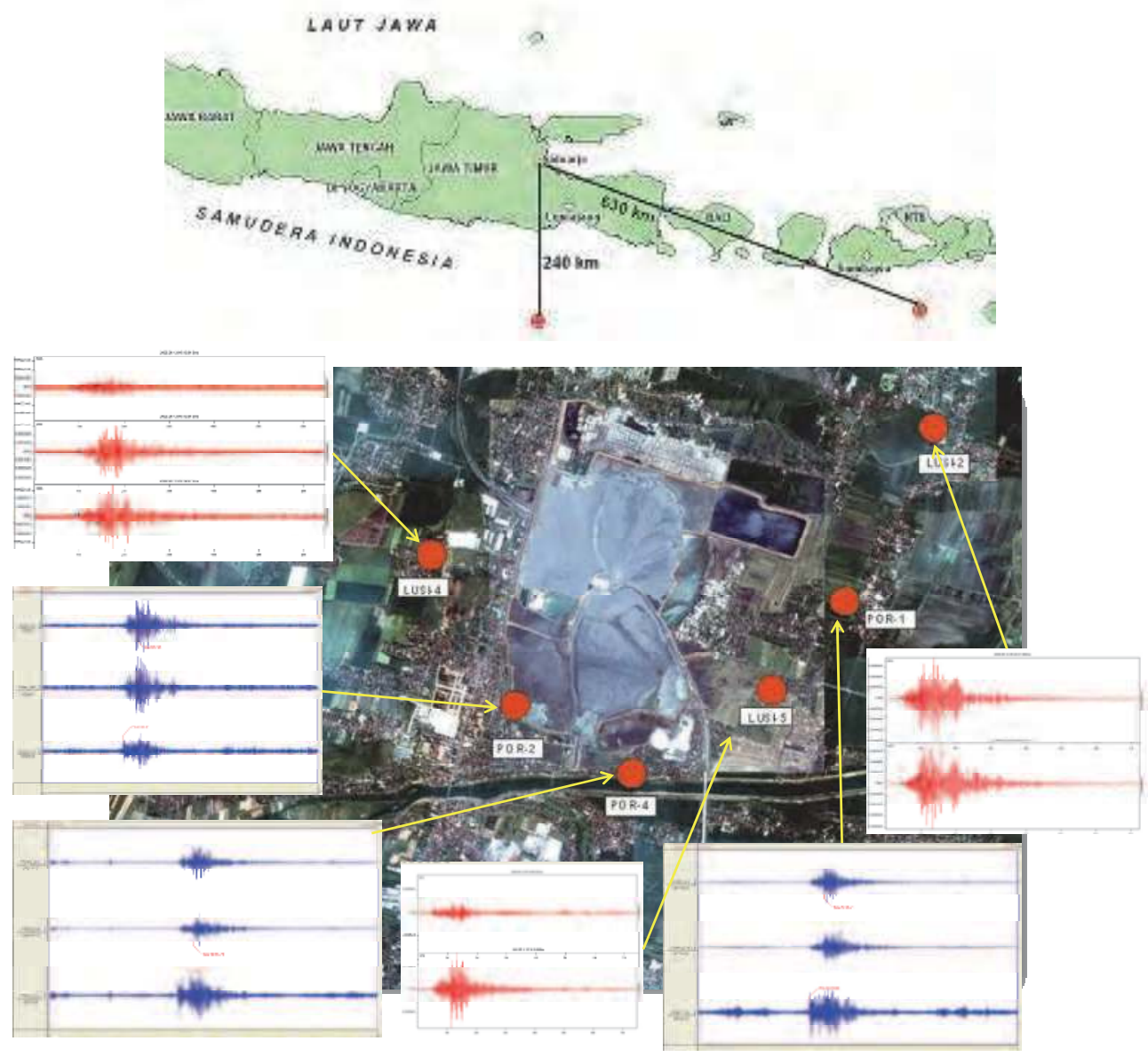

Fig. 14. (A) Epicenter locations of June 1st and 12th 2008 earthquakes located about $240 \mathrm{~km}$ and $630 \mathrm{~km}$ respectively from LUSI. (B) LUSI Microseismic monitoring network located around the center of the main crater. Seismographs show the June 12th 2008 earthquake with an epicenter located about $240 \mathrm{~km}$ South of LUSI. 
equipped with a digital recorder system that records continuously for 24 hours, and GPS was used as timing marks on the seismic wave data. Data was processed by analyzing the arrival time of the P wave and S wave. The results of "picking" or "reading arrival rate" was analyzed with appropriate software, to determine the source of vibration.

To determine the location of the vibration source or microseismic hypocenter requires seismic wave velocity data at LUSI location. Wave velocity data was obtained from seismic surveys and wells logging data during drilling. Processed results in the form of coordinates of the location of the source of the wave system are plotted in three dimensions, so that the pattern of its occurence can be seen clearly. To facilitate processing, field data which is a mixture of different frequencies and microseismic noise are filtered, so as to identify microseismic events, arrival time, $\mathrm{P}$ wave and $\mathrm{S}$ wave, maximum amplitude and duration. All data was processed to determine the parameters of microseismic, namely: the timing, location coordinates, depth and magnitude. The results of the data processing are classified into two types of earthquakes, namely: the earthquake which occurred outside LUSI, and those that occurred around LUSI. In this case we will focus on earthquake data that occurred outside the LUSI area to determine earthquake response to changes in temperature, gas flux and behaviour that occur in the main vent.

The ability to detect an earthquake depends on the magnitude of the earthquake, the sensitivity of the sensors (seismometers), and the distance between the hypocenter and the location of the sensors. In general, earthquakes in Indonesia with magnitudes above 5.0 on the Richter scale, will be recorded by almost all seismograph networks in Indonesia. Like the two above mentioned tectonic earthquakes, wave energy can propagate from the source to the sensor around LUSI, with greater strength than the noise level around the sensors.

\begin{tabular}{|c|c|c|c|c|c|}
\hline \multirow{2}{*}{ No. } & \multirow{2}{*}{ Stations } & \multicolumn{2}{|c|}{ Coordinates } & \multirow{2}{*}{ Periods } & \multirow{2}{*}{ Agency } \\
\cline { 3 - 4 } & & Latitude & Longitude & 29 April - 5 July 2008 & BMKG \\
\hline 1 & POR 1 & -7.53084 & 112.73086 & 29 April - 5 July 2008 & BMKG \\
\hline 2 & POR 2 & -7.54043 & 112.70377 & 29 & BMKG \\
\hline 3 & POR 4 & -7.54414 & 112.71470 & 29 April - 5 July 2008 & BMK \\
\hline 4 & LUSI 2 & -7.51485 & 112.74049 & 29 April - 5 July 2008 & BMKG \\
\hline 5 & LUSI 4 & -7.52660 & 112.69772 & 29 April - 5 July 2008 & BMKG \\
\hline 6 & LUSI 5 & -7.53700 & 112.72535 & 29 April - 5 July 2008 & BMKG \\
\hline
\end{tabular}

Table 1. Coordinates of microseismic network stations in the area LUSI.

During the monitoring period two tectonic earthquake occurred outside LUSI. These are:

1. June 1, 2008, Time 15:59:50.2 GMT, the epicenter was located at latitude 9.53० South longitude 118.04 East, at a depth of $90 \mathrm{~km}$ with a magnitude of $5.5 \mathrm{SR}$, about $630 \mathrm{~km}$ from LUSI

2. June 12, 2008 At 05:19:55 GMT, the epicenter was located at latitude 9.68 South longitude $112.67 \mathrm{o}$ East, at a depth of $15 \mathrm{~km}$ and magnitude of $5.4 \mathrm{SR}$, about $240 \mathrm{~km}$ from LUSI.

In addition to microseismic monitoring, temperature, LEL (low explosive limit- in air where $20 \%$ LEL corresponds to $10000 \mathrm{ppm}$ ), and $\mathrm{H}_{2} \mathrm{~S}$ concentration monitoring was continuously 
performed using portable monitoring equipment by BPLS (Sidorajo Mud Mitigation Agency) officers in the field. Measurements from 1 to 20 June 2008 showed a fluctuation LEL, H2S, and temperature at the center of eruption. The peak value of the measurement period occurred on June 12 and 13, 2008, in which all measurement parameters rose sharply, particularly temperature and the concentration of $\mathrm{H}_{2} \mathrm{~S}$ (see figure 15).

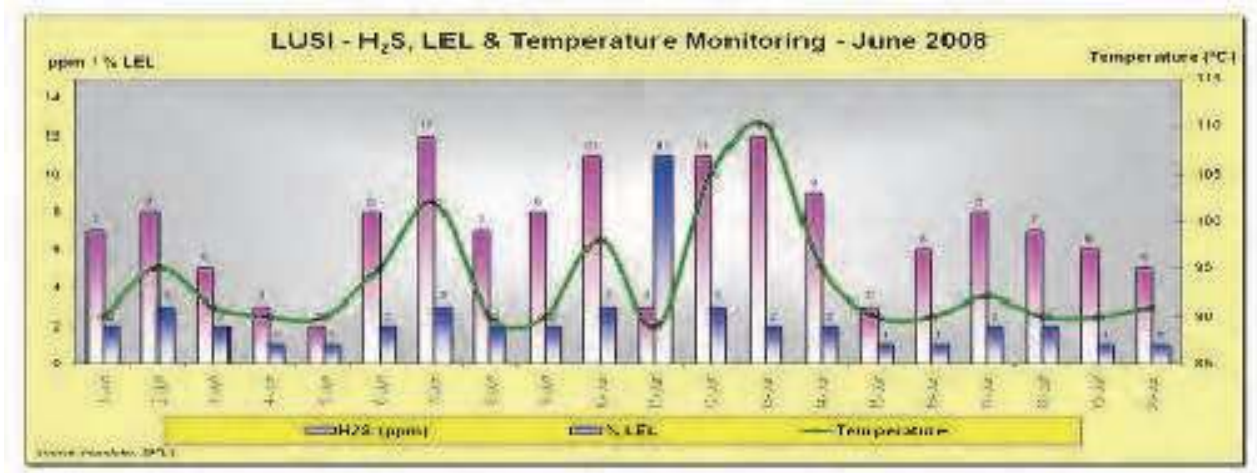

Fig. 15. Correlation between LUSI mud volcano activity and earthquakes. Increasing gas expulsion, temperature and mud eruption rates after earthquake are shown in the above graph after the $12^{\text {th }}$ of June $20085.5 \mathrm{Mw}$ earthquake. The epicenter was located some $240 \mathrm{~km}$ South of LUSI.

The increase in temperature positively correlates with data from the installed seismograph network around LUSI which showed an earthquake occurred approximately $240 \mathrm{~km}$ south of LUSI on June 12, 2008. In The case of LUSI, the earthquakes have affected the rheology of fluid in term of permeability, changing the viscosity and the rate of mud eruption, consequently the increased concentration of expelled gases and temperature.

\subsection{Horizontal displacement}

Geodetic measurements were conducted at the LUSI site to quantify the ongoing deformation processes. The primary data sources were the GPS surveys periodically conducted at monitoring stations to measure vertical and horizontal movements relative to a more stable reference station. Seven GPS survey campaigns were conducted between June 2006 and April 2007. The GPS measurements were conducted at 33 locations using dualfrequency geodetic type receivers over various time intervals. Each measurement lasted from 5 to $7 \mathrm{~h}$. (Istadi et al., 2009).

Areas within a 2-3 km radius of LUSI's main mud eruption vent are experiencing ongoing horizontal and vertical movement aligned to major faults. The horizontal displacements have spatial and temporal variations in magnitude and direction, but generally follows the two major trends, namely in the direction of NE - SW and NW - SE (see figure 16). Rates of horizontal displacement are about $0.5-2 \mathrm{~cm} /$ day, while vertical displacements are about $1-4 \mathrm{~cm} /$ day, with rate increasing towards the extrusion centre (Abidin et al, 2008). 


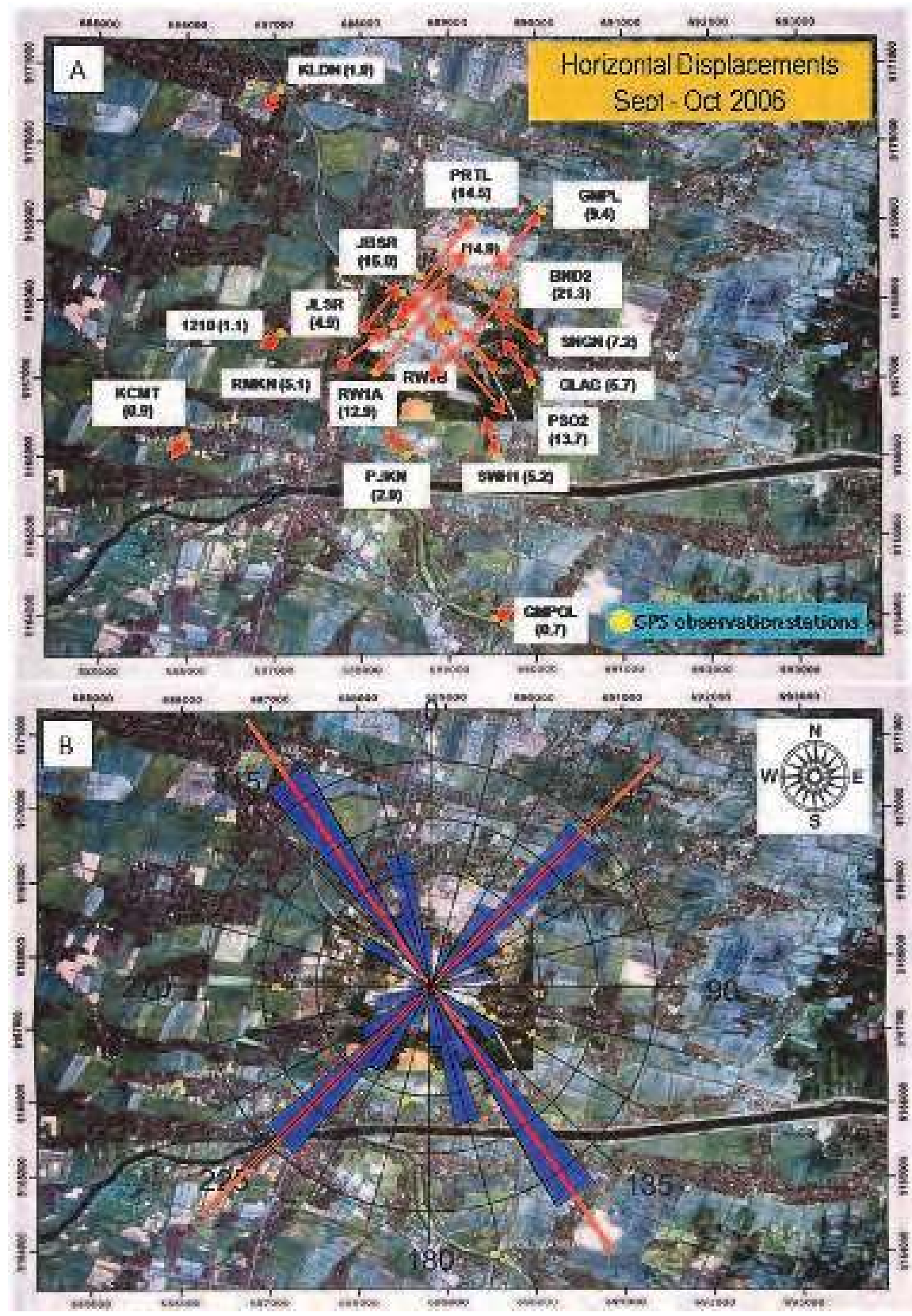

Fig. 16. (A). Horizontal displacement measurements in September - October 2006. Directions of the red arrows show the direction and magnitude of movement. (B). Measurements from June 2006 - March 2007 indicate the major trends are NW-SE and NE-SW as seen in the rose diagram. 


\subsection{Subsidence and uplift}

Five years after the mud eruption, the area near LUSI has subsided at a considerable rate. Buildings and houses near the eruption site have completely disappeared under layers of mud. However, in the east and northeast uplift is occurring. To measure both the subsidence and uplift, four survey campaigns were conducted (Table 2):

\begin{tabular}{|c|c|c|c|}
\hline Start & End & Points & Method \\
\hline July 2006 & March 2007 & 25 & GPS \\
\hline Dec. 2007 & April 2009 & 30 & Total Station \\
\hline Dec. 2008 & Feb. 2011 & 15 & GPS \\
\hline Dec. 2008 & Feb. 2009 & 5 & Level \\
\hline
\end{tabular}

Table 2. Four survey methods to measure elevation near LUSI MV

Data from these four surveys was used to show the changes in elevation, subsidence and uplift, as well as horizontal movement over time. Subsidence contour maps were created using GIS software by interpolating the measurement data. The results showed an almost concentric pattern shown in Figure 17.

The subsidence started as a crack in the ground that continued to grow and decrease its elevation. The existence of subsidence was evidenced by, among other things, the pattern of ground cracks, tilting of houses, cracking of flyover and bridges, as well as collapsing of buildings. The direction of the cracks varies depending on its location. In the Renokenongo area, southeast of LUSI, the cracks direction is NE- SW, whereas in West Siring area, west of LUSI, the cracks are North-South.

Subsidence and horizontal movements indicate the dynamic geological changes in the area. These movements have caused reactivation of pre-existing faults or newly formed faults. The continued movements along faults would likely result in the emergence of more fractures and gas bubbles (see figures 17 and 18).

Subsidence continues as the mud eruptions progress. The subsidence might result from any combination of ground relaxation due to mudflows, loading due to the weight of mud causing the area to compact, land settlement, geological structural transformation and tectonic activity (Abidin et al., 2007).

Based of field measurements, areas up to $3 \mathrm{~km}$ from the main eruption vent are experiencing subsidence to some degree. Presently however, due to much reduced volumes of mud eruption, the measured rate of subsidence on the West side of main eruption vent indicate a decrease from the original $25 \mathrm{~cm} /$ month when LUSI was very active in the first year, to less than $5 \mathrm{~cm} /$ month. If the decreasing trend continues, the affected subsidence area will likely decrease from earlier prediction of more than $3-4 \mathrm{~km}$. 


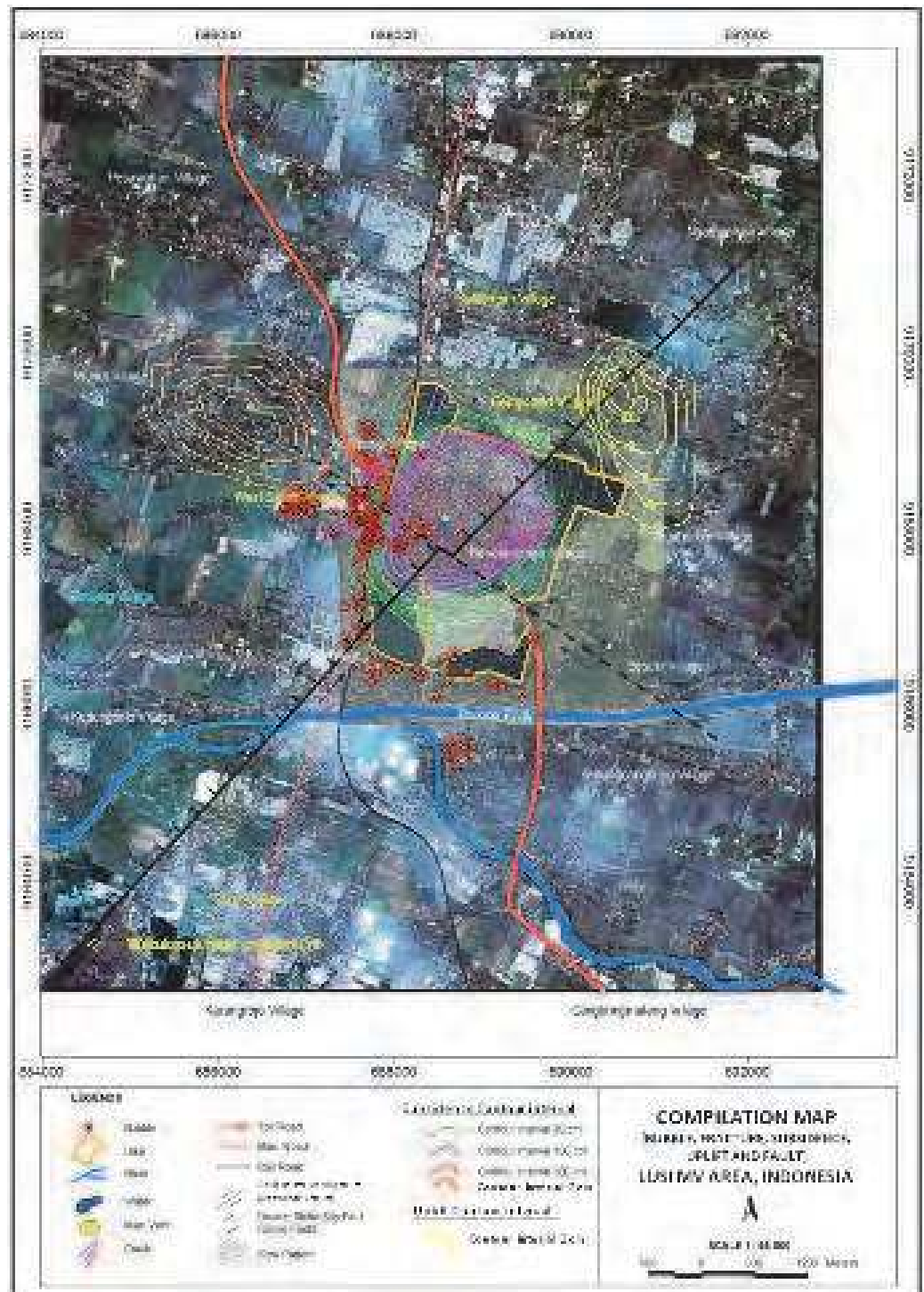

Fig. 17. LUSI post eruption map. The subsidence contour is status as of January 2010, constructed by interpolating the measurement data, and was created using GIS software. The contour showed an almost concentric pattern. The area West of the main vent was subsiding faster than other areas.

The map also shows fractures distribution around LUSI. East of the main vent, fractures trend NE - SW, whereas West of the main vent the fracture trend is North-South. The Gas bubble distribution around LUSI status in May 2011 where more than 220 gas bubble locations have been recorded since the start of LUSI eruption in May 2006. Presently only a few are still active. 


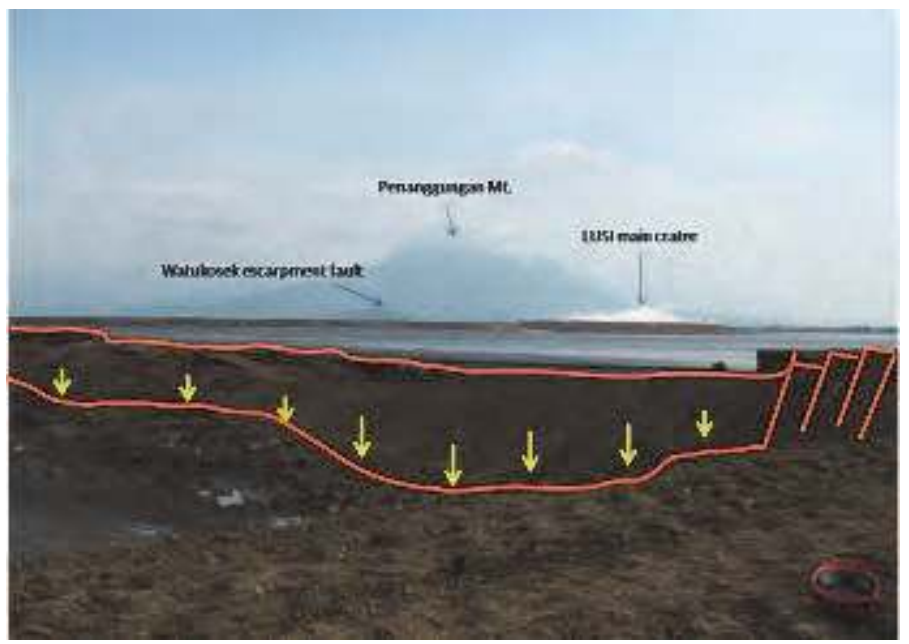

Fig. 18. Photo showing subsidence and collapse of the retaining mud dyke northeast of the LUSI main vent that occurred on 21 May 2008. In some parts, where slumping and subsidence occurred, local small scale faulting at the edge of subsiding wall occured. The continued subsidence proves very difficult to maintain the dyke.

\subsection{InSAR data}

InSAR (Interferometric Synthetic Aperture Radar ) is a technique to map ground displacement with a high resolution of up to centimeter-level precision (e.g. Massonnet and Feigl, 1998; Hanssen, 2001). InSAR is effective tool to measure the amount of ground deformation caused by earthquake, volcanic activity has been useful for studying land subsidence associated with ground water movements (e.g. Amelung et al., 1999; Gourmelen et al., 2007), mining (e.g. Carnec and Delacourt, 2000; Deguchi et al., 2007a), and geothermal as well as oil exploitation (e.g. Massonnet et al., 1997; Fielding et al., 1998). The amount and pattern of deformation are shown by a range of colors in the spectrum from red to violet. The computed interferograms are interpreted using an inversion method that combines a boundary element method with a Monte-Carlo inversion algorithm (Fukushima et al., 2005). In LUSI, this technique was used to determine the surface deformation due to the mudflow starting from 19 June 2006 (three weeks after the mud eruption) to 19 February 2007. The measurement was done using PALSAR (Phased-Array L-band SAR) onboard the Japanese Earth observation satellite ALOS. Measurement of land subsidence is possible as the L-band microwave is less affected by vegetation (Deguchi et al., 2007a).

Deguchi et al. (2007a, 2007b) and Abidin et al. (2008) performed a study and measured the ground subsidence temporal changes of deformation obtained by applying time-series analysis to the deformation results extracted by InSAR.

- From 19 June 2006 to 4 July 2006 the subsidence showed an elliptical pattern, suggesting subsidence around the main vent and west of the main vent.

- From 4 July 2006 to 19 February 2007, the scale of subsidence and uplift became more significant. Both subsidence and uplift East of the main vent became more pronounced. In contrast to the high rate of mud eruption however, the InSAR results clearly showed that the ground deformation associated with mud eruption decreased after November 2006. 
The results from the use of InSAR indicate subsidence has occurred in this area. Four different areas of deformation is suggested, these include areas centered around the main eruption vent; areas to the west-northwest of the main vent; areas to the northeast of main vent; and to the southwest of the main vent. Apart from the areas to the west-northwest which is associated with the deformation due to gas production in Wunut gas field, the other 3 deformation areas follow the regional fault pattern, contiguous to the Watukosek NE-SW fault trend.

The results also demonstrate the progressive subsidence evolution from time to time during the period of measurement. Subsidence in the main eruption area showed the most rapid subsidence rates. The 8-months measurements period showed ellipsoidal subsidence pattern covering an area of approximately $2 \times 3 \mathrm{~km} 2$ with a long axis trending NE-SW.

Another area to the west-northwest of the main eruption area is also experiencing subsidence. This particular area is within the Wunut gas field which covers approximately 2 $X 2.5 \mathrm{~km} 2$ with long axis trending NW-SE. This trend corresponds to the regional Siring NW-SE fault trend.

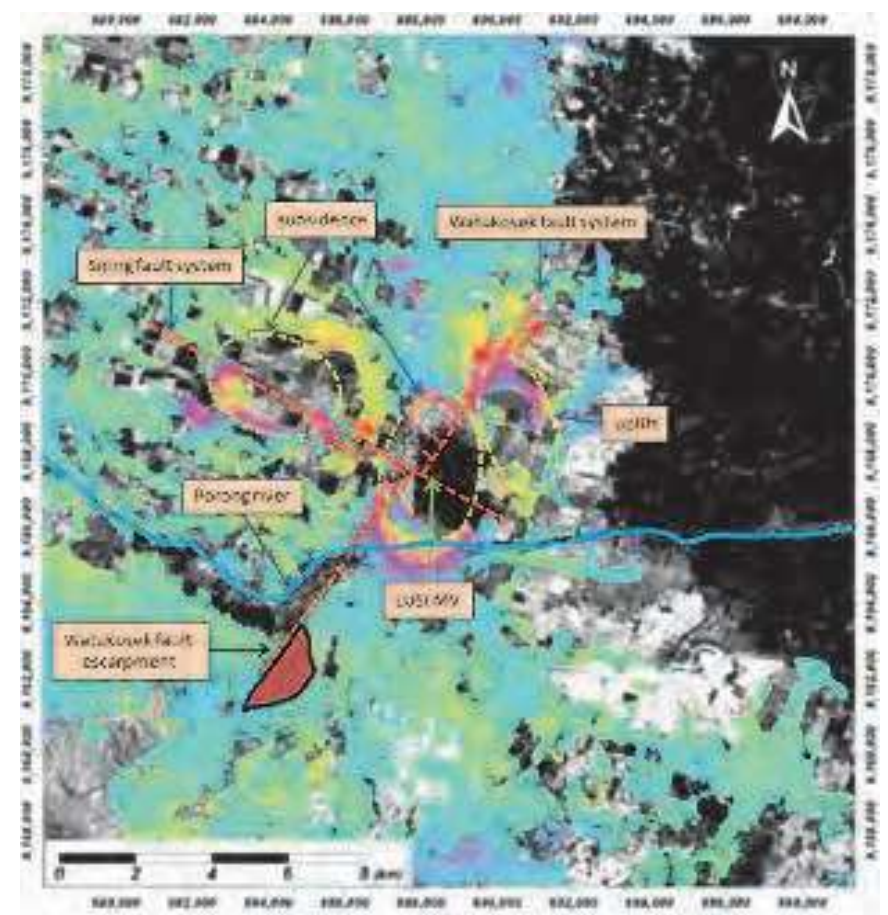

Fig. 19. The interpreted results of InSAR satellite imagery in February 2007 suggest an elliptical subsidence along the NW - SE long axis with a distance of 1-2 km from the main eruption vent, namely in the area around West Siring and Pamotan. In the vicinity of the main mudflow and the eastern regions about $2.5 \mathrm{~km}$ northeast of the main eruption, the subsidence occurred elliptical on the N-S long axis.

(figures modified from Deguchi et al, 2007)

Fault reactivation resulted in horizontal and vertical movement, which later manifested in the formation of uplift and subsidence or vertical and horizontal offset. An overlay of the 
ellipsoidal InSAR measurements with regional faults in these areas indicate a correlation between the two. Elipsoidal uplift suggest the long axis trending NNW - SSE is a restraining stepover to offset oblique strike slip fault of the reactivated Watukosek fault.

It is interesting to note that the InSAR measurements found that the deformation diminished after November 2006, only 6 months after the start of the eruption. Interpretation of interferogram for each periodic cycle for the period of May to July 2006 (beginning of eruption) showed more temporal change of deformation compared to the period of November 2006. In contrast, during the period of October - November 2006 field observations indicate increasing intensity of subsidence in the western side of the main vent, particularly in the village of Siring Barat. The main eruption vent and surrounding central area were experiencing most rapid rate of subsidence and continual collapse of the mud retaining dykes. Areas to the E-NE of the main vent were experiencing increases in uplift. The indication of contrasting InSAR measurements could be interpreted as lesser or diminishing effect of initial fault reactivation that triggered LUSI.

Interpretation of interferogram by Deguchi suggesting psudo anomaly in an area to the northeast of the main vent and does not indicate uplift based on conversion to rectangular coordinates (see Deguchi et al, 2007b). Field observation however suggest an uplift has occurred in areas to the east and northeast of the main eruption, in the Renokenongo village and surrounding areas. The uplifted area covers an area of approximately $1 \times 1.5 \mathrm{~km} 2$ with a long axis trending NNW - SSE.

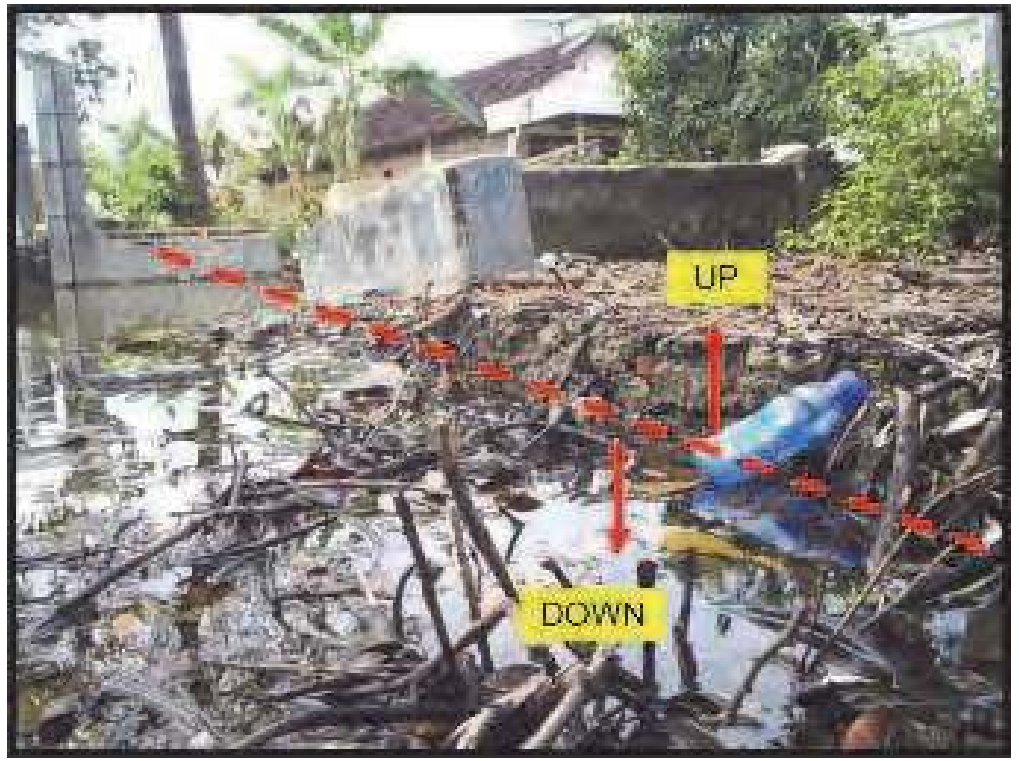

Fig. 20. The pattern of fractures trending NE -SW in the Village Renokenongo. A section of land on the right hand side of the picture is uplifted (east side) while the left is the downthrown block (west side). Note: The mineral water bottle is used as a comparison to indicate the amount of displacement $(\sim 20 \mathrm{~cm})$. In contrast to Degushi et al., $2007 \mathrm{~b}$ psudo anomaly interpretation, the above photo taken 2 months after the eruption suggests displacement due to fault movement. Movement due to subsidence was unlikely as it was minimal at the early stages of the eruption. 


\subsection{Fracture orientation}

Fractures appeared around LUSI area as a result of loss of cohesion due to ground movement, both vertical and horizontal movements. These fractures were concentrated mainly to the East of the main eruption (Renokenongo village), around the main vent and to the West (Siring Barat village), with displacements of varying degree and magnitude. The fractures follow the sinistral Watukosek NE - SW trend. Juxtaposed with the Watukosek fault reactivation, is the Siring fault movement that trends NW - SE which has dextral strike slip movement. These fractures were caused by reactivation of faults but their orientation pattern are often not apparent due to thick alluvial cover.

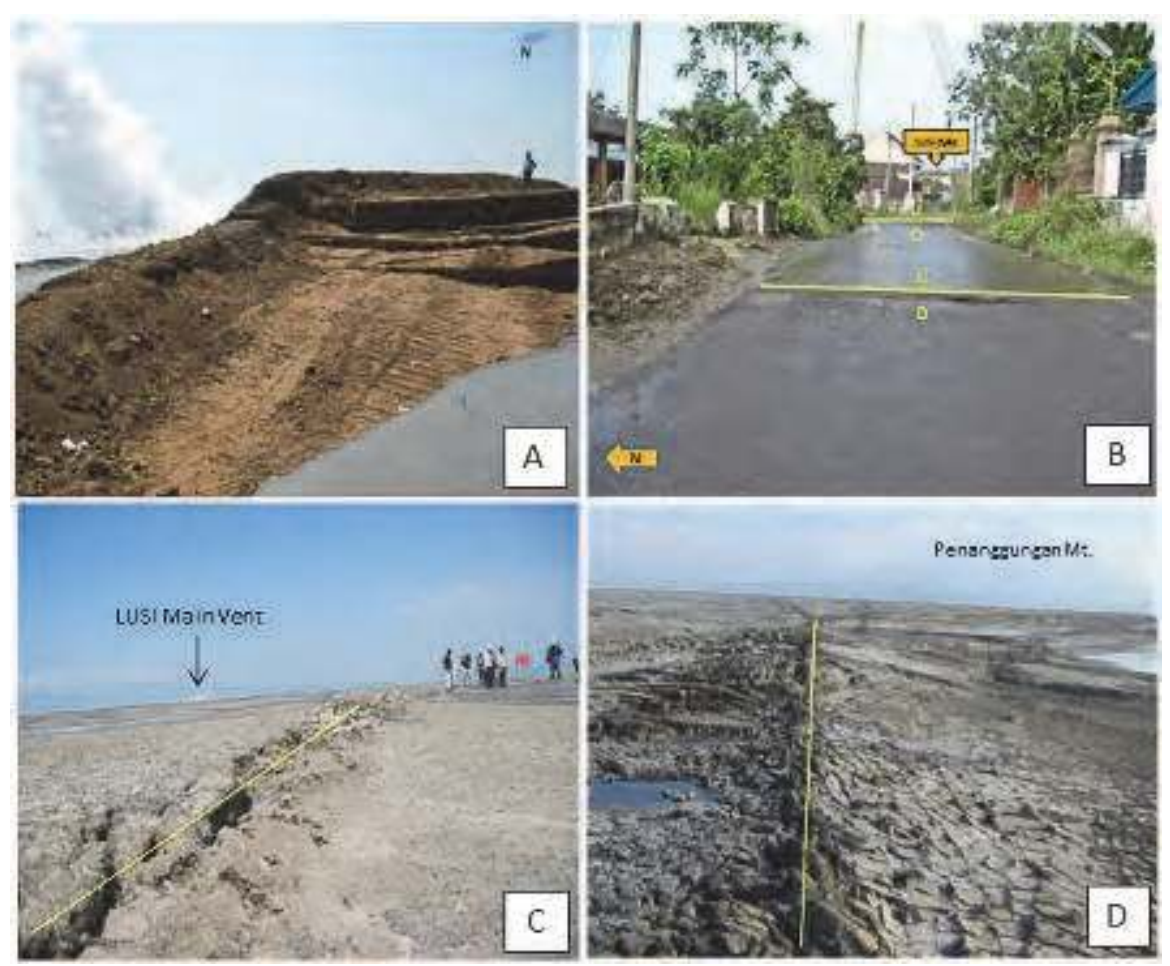

Fig. 21. (A). On June 2, 2008 the dyke on the East side of the main vent broke with an orientation NE-SW. Then on June 8, 2008 the $40 \mathrm{~m}$ long dyke collapsed as deep as 6 meters. (B). Fractures on the West Siring village west of the main vent showed an orientation trending North - South. (C)\&(D) an active fault is located west of the main vent and trends North - South.

\subsection{Gas bubbles}

Gas bubbles of various sizes and pressures started to appear two days after the mud eruption. Those that appear from water wells generally have a higher pressure and high methane concentration than bubbles from surface fractures (see figure 22). The ejected materials from these gas bubbles typically had some water, mud with minor sand. A total of over 220 gas bubble locations have been identified since the start of the eruption, however 
the number that are still active continually decrease. Presently less than 20 gas bubbles are still active, suggesting LUSI is entering a more stable and less active phase.

Gas bubbles are not continuous; they may burst for several weeks or months then stop and reappear elsewhere. Some gas bubbles appear in straight lines that are contiguous with the fault trends. These gas bubbles are mainly concentrated on the West and South of the main eruption which reflect the existence of subsurface gas accumulation breached by deep fractures. The gas accumulation is believed to be a part of the Wunut gas field flanks with its sealing capacity breached by the reactivated Watukosek faults or newly formed fractures as a result of rapid subsidence in the area.
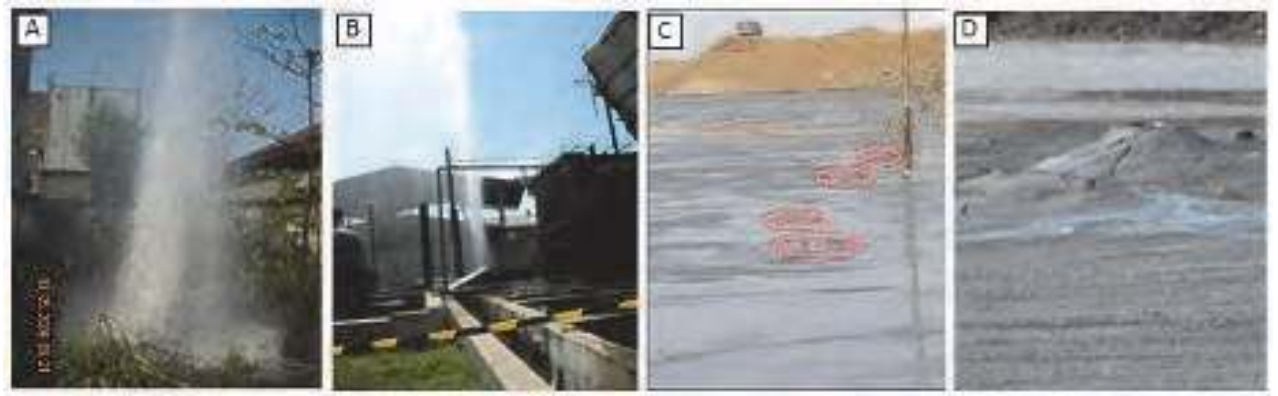

Fig. 22. (A) \& (B) The gas bubble originating from water wells, with tremendous pressure and high content of methane gas. Besides removing water,the bubbles also ejected sand, shell fossils and a bit of mud from the swamp sediments. (C) Gas bubbles along the fracture to the west of the main vent, low pressure and in clusters. (D) a Gryphon located approximately $400 \mathrm{~m}$ west of the main vent.

Gas bubbles around the mud volcano have formed gryphons of around $30 \mathrm{~cm}$ in diameter and height of around $40 \mathrm{~cm}$ (see figure 22D). The ejected material was mainly methane gas and some water (see figure $22 \mathrm{~A}$ and $\mathrm{B}$ ).

\subsection{Source of mud, water, gas and heat}

Mud material ejected from the mud volcanoes is believed to have originated from shale layers known as 'Bluish Gray' clay of the Upper Kalibeng Formation of Plio-Pleistocene in age. The similarity between the mud and the cutting samples from the nearby well Banjarpanji-1 from a depth of $1220-1828$ meters is based on the following:

1. The similarity of foraminifera and nanno fossil collection, as well as index fossils containing Globorotalia truncatulinoides and Gephyrocapsa spp. that are Pleistocene in age. Benthos Foram collection shows that the sediment was deposited in the marine environment in the inner to middle neritic zones, ranging from shoreline to a depth of 100 meters.

2. Kerogen composition correlates with the side wall core from Banjarpanji -1 at a depth of $1707 \mathrm{~m}$.

3. Thermal maturity based Vitrinite reflectance (Ro) correlates with cuttings and side wall core samples from Banjarpanji-1 at a depth of 1554-1920 meters.

4. Clay mineral composition has similarities with samples from the side wall core from Banjarpanji -1 at a depth of 1615-1828 meters where the illite content in illite-smectite mixture reached $65 \%$. 
LUSI muds contain various types of clay including smectite, kaolinite, illite and minor chlorite. It is known that illite minerals form at temperatures between 220 to $320^{\circ} \mathrm{C}$, smectite forms at surface temperatures of up to $180{ }^{\circ} \mathrm{C}$ and altered minerals chlorite forms at temperatures between $140-340{ }^{\circ} \mathrm{C}$. The XRD analyses carried out on core samples from Banjarpanji-1 imply an intensive progressive smectite-illite transformation with the depth. This suggests that the intersected Upper Kalibeng Formation was exposed to a minimum temperature of $220^{\circ} \mathrm{C}$.

In the initial stages the volume of water in LUSI was very large reaching up to $70 \%$ of the total volume of mud with an average salinity of $14,151 \mathrm{ppm} \mathrm{NaCl}$. The lower salinity than sea water suggests dilution. At the time of writing, the liquid composition made up $30 \%$ of the total volume. The source of water has been debated by various researchers. Davies et al (2007) states that the water originates from the carbonate Kujung formation, while Mazzini et al (2007) based on geochemical data concluded that the high-pressure water is derived from clay diagenetic dehydration of Upper Kalibeng Formation.

Indonesian Geological Agency, Ministry of Energy and Mineral Resources in 2008

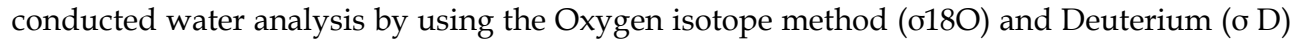
to determine the magmatic origin of LUSI. Results showed deuterium concentration $(\sigma D)$ from $-2.7 \%$ o to $-13.8 \%$ and Oxygen- 18 (o18O) from $+7.59 \%$ up to $+10.11 \%$, and high Chloride content of 12,000 -17,000 ppm. Based on the above they concluded that the water source of LUSI is associated with igneous rock sourced from magma (Sutaningsih et al., 2010).

Perhaps it is quite impossible to determine the source of water as it could be a mixture of different sources, ie. clay diagenetic dehydration, carbonates, deeper source linked to geothermal, trapped water due to disequilibrium compaction and mixing with shallow meteoric waters. The importance of determining the source is for hydro-geological purposes, in handling the impact of the mud flow, its effect to the environment and contamination to the ground water. If the fluid is old (Tertiary), it is trapped water, whereas, if the water is young (Quaternary), it is likely to be recharged upslope. For the former, naturally, the eruption will stop after a certain time, whereas, for the later condition, the eruption will never stop (Hutasoit, 2007). However, Sunardi et al., 2007 suggested that LUSI will likely stop when hydrostatic pressure equilibrium is reached.

Groundwater samples from LUSI and its surrounding gas bubbles near the main vent have been chemically analyzed for major anions $\left(\mathrm{Cl}^{-}, \mathrm{HCO}_{3-}\right.$, and $\left.\mathrm{SO}_{4}{ }^{2-}\right)$ and cations $\left(\mathrm{Na}^{+}, \mathrm{K}^{+}, \mathrm{Ca}^{2+}\right.$, and $\left.\mathrm{Mg}^{2+}\right)$. The result shows that there is a significant difference in water chemistry between the main vent and the bubble. The concentration of $\mathrm{Cl}^{-}, \mathrm{Na}^{+}, \mathrm{Ca}^{2+}$, and $\mathrm{Mg}^{2+}$ in the main vent water are much higher. This suggests that the water may be from different sources, or both are from the same source, but the gas bubble water has been diluted by shallow groundwater. The second case implies that the pressure in the gas bubble areas may be depleting so that shallow groundwater is mixed with deeper sourced water. If the pressure is still high, then flow from the eruption area will contaminate the shallow groundwater. In either case, the ongoing subsidence is also caused by the decreasing pore pressure as the water is discharged to the surface.

The composition of the erupted gas sampled in July in the proximity of the crater showed $\mathrm{CO}_{2}$ contents between $9.9 \%$ and $11.3 \%, \mathrm{CH}_{4}$ between $83 \%$ and $85.4 \%$, and traces of heavier hydrocarbons. In September, the steam collected from the crater showed a $\mathrm{CO}_{2}$ content up to $74.3 \%$ in addition to $\mathrm{CH}_{4}$. Simultaneously, the gas sampled from a $30.8^{\circ} \mathrm{C}$ seep $500 \mathrm{~m}$ away 
from the crater had a lower $\mathrm{CO}_{2}$ content $(18.7 \%)$. The four gas samples collected during the September campaign were analysed for $\delta^{13} \mathrm{C}$ in $\mathrm{CO}_{2}$ and $\mathrm{CH}_{4}$. The $\delta^{13} \mathrm{C}$ values for $\mathrm{CO}_{2}$ and $\mathrm{CH}_{4}$ vary from $-14.3 \%$ o to $-18.4 \%$ ond from $-48.6 \%$ o to $-51.8 \%$, respectively (Mazzini et al., 2007). The relatively low $\delta^{13} \mathrm{C}_{\mathrm{CH} 4}(-51.8 \%$ o $)$ indicates input from biogenic gas mixed with a thermogenic contribution. The biogenic gas was derived from immature shale layers, probably from the overpressured shale at a depth of 1323-1871 meters, whilst the thermogenic gas was derived from shale layers that are more mature, probably of Eocene age. The $\mathrm{CO}_{2}$ is postulated to come from the dissolved $\mathrm{CO}_{2}$ in the water of the shale layer, at temperatures above $100{ }^{\circ} \mathrm{C}$ and low pressure. The constant presence of $\mathrm{H}_{2} \mathrm{~S}$ since the beginning of the eruption could also suggest a contribution of deep gas or, most likely, $\mathrm{H}_{2} \mathrm{~S}$ previously formed at shallow depth in layers rich in $\mathrm{SO}_{4}$ and/or methane or organic matter. The rapidly varying composition of the erupted gas indicates a complex system of sources and reactions before and during the eruption (Mazzini, 2007).

Temperatures measured from a mud flow within $20 \mathrm{~m}$ of the LUSI crater revealed values as high as $97^{\circ} \mathrm{C}$ (Mazzini, 2007, 2009). Given the visible water vapor and steam this suggests temperatures above $100{ }^{\circ} \mathrm{C}$. The heat source of the erupted mud is believed to be from a formation at a depth of over $1.7 \mathrm{~km}$ where the temperature is over $100{ }^{\circ} \mathrm{C}$. Geothermal gradients of c. 42 and $39{ }^{\circ} \mathrm{C} / \mathrm{km}$ have been reported in the area. With such a high temperature gradient, LUSI can be viewed as a geo-pressured low temperature geothermal system that discharged hot liquid mud close to its boiling point the first four years of its life (Hochstein and Sudarman, 2010). Hochstein believed that the high temperature gradients are likely due to the low thermal conductivity of the highly porous, liquid saturated reservoir rocks. Mazzini, on the other hand, believed that the high geothermal gradient is due to the close proximity to Mount Arjuno-Welirang (about $40 \mathrm{~km}$ ), which is part of the Java volcanic arc that formed since the Plio-Pleistocene (Mazzini, 2007, 2009).

Two shallow ground temperature surveys carried out in 2008 showed anomalously low temperatures at $1 \mathrm{~m}$ depth (possibly due to a Joule-Thompson effect of rising gases) and liquid mud temperature that varied between 88 and $110{ }^{\circ} \mathrm{C}$ with the highest temperatures occurring after a large, distant earthquake. The mud temperature of mud volcanoes is controlled by the gas flux (endothermic gas depressurizing induces a cooling effect), and by the mud flux (mud is a vector for convective heat transfer) Deville and Guerlais (2009).

\subsection{Geomorphology of the area}

In general, the geomorphology in Porong and the surrounding area is divided into 5 units: Under the volcanic slopes unit, Foot volcanic plateau unit, Cuesta unit, Alluvial plains unit, and Mud volcano unit. The geomorphological units division is based on morphology, the height difference and slope (Desaunettes, 1977).

\subsubsection{Under the volcanic slopes unit}

The unit is located at the northern foot of the Penanggungan mountain or in the Proximal facies. This unit is distributed mainly in the southern area of LUSI, adjacent to the mountain range. Lithologic constituents of the unit are generally in the form of volcanic breccia, tuff, lava, tuffaceous breccias, lava and agglomerates and the presence of shallow andesite intrusions in small dimensions. The dominant process in this unit is volcanism. Volcanism processes of Penanggungan Mountain produce volcanic cone morphology. The pattern of distribution in this area is a radial pattern. 


\subsubsection{Foot volcanic plateau unit}

This unit has the morphology of the plains at the foot of Penanggungan mountain or in the medial facies. The unit was formed from the deposition of material surrounding the volcano eruption as laharic. Laharic deposits are found in the form of loose sand and gravel to bouldersized fragments as products of volcanic eruptions. There is a wide variety of bedding igneous rock fragments to the level of weathering, colors and dimensions.

Lithologic constituents of this unit are fine tuff, sandy tuff, tuff and tuffaceous breccia. The dominant processes in this unit are erosion and sedimentation. The pattern of distribution in this area is a radial pattern.

\subsubsection{Cuesta unit}

The Cuesta unit is primarily distributed in the southern area of LUSI. The highest point is at an elevation of $150 \mathrm{~m}$ at the top of the Watukosek hill. The lowest point is at an elevation of $20 \mathrm{~m}$ on the valley of Watukosek. The dominant process in this unit is a tectonic process of faulting, which resulted in shear faults and the down thrown block to the West to form a steep escarpment in the area of Watukosek. This escarpment is known as the Watukosek Escarpment. Lithologic constituents are of andesite breccia, sandstone and tuff. Morphology in the region reflects the existence of Watukosek fault as indicated by the presence of steep slopes on the western escarpment while relatively gentle on the eastern slopes. The pattern of distribution in this unit is trellis pattern.

\subsubsection{Alluvial plain unit}

Alluvial plains unit make up most of the area and are widely distributed near LUSI. Geomorphological slope is approximately $0-5 \%$. Lithologic constituents are loose sand deposits, clay, sandy clay.

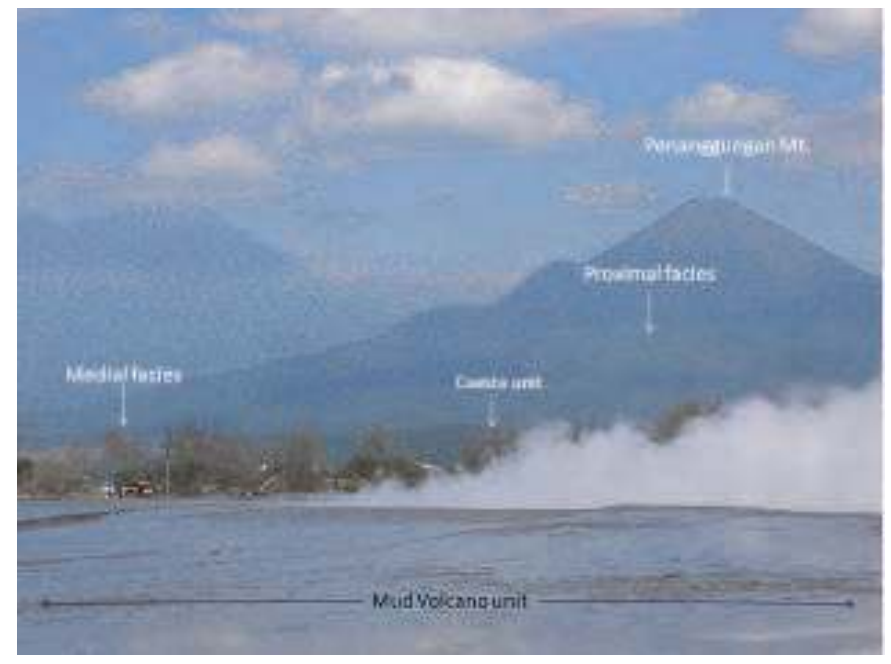

Fig. 23. LUSI area showing the division of volcanic facies. The central facies is located at the top Penanggungan mountain, proximal facies on the upper slopes and medial facies on the foot slope below the mountain. LUSI overlies the alluvial plains which are approximately10 $\mathrm{km}$ from Penanggugan mountain. 
This geomorphological unit is controlled by alluvial rivers. Geologic processes that act on this unit are erosion, transport and deposition. Lateral erosion took place due to slopes of the mountains to the South causing lateral erosion to be more effective than vertical erosion. In this area there are large rivers namely Porong River which is flowing from West to East that ends up in the Madura Strait. Structural control is clearly visible on the morphology in this area evidenced by the abrupt deflections in the Porong River that follows the fault pattern.

\subsubsection{Mud volcano unit}

The unit was formed due to discharge of mud from formations below the surface. The morphology is like a low relief hill. The mud volcano Unit is limited by the retaining dykes so that the mud does not spill over into surrounding areas. This unit includes the Village of East Siring, Jatirejo, Tanggulangin Glagaharum, Ketapang and surrounding areas. Lithologically this unit is predominantly the mud itself that contain some fossils.

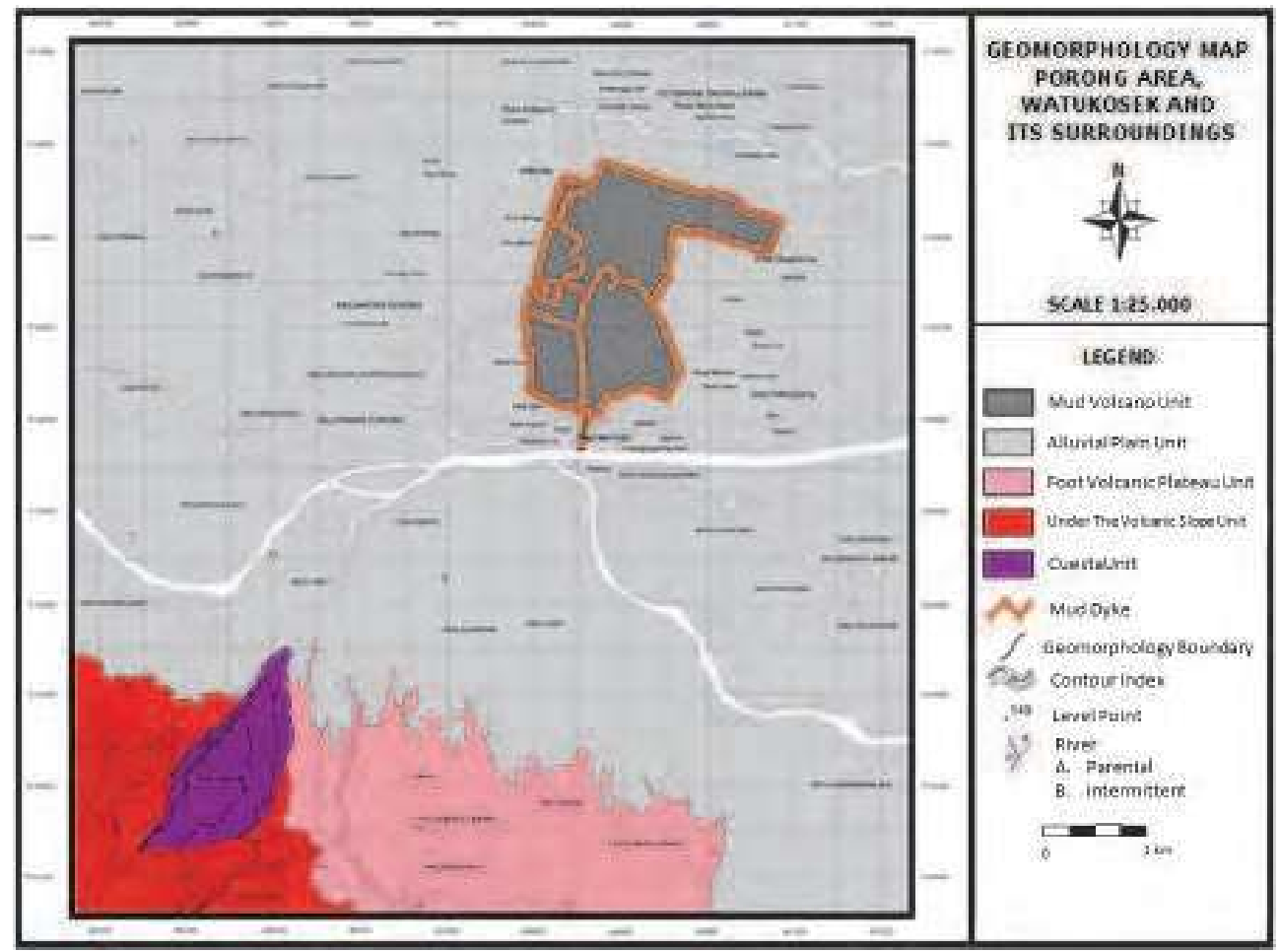

Fig. 24. Geomorphology map of the Watukosek area.

The morphological shape of LUSI is a semi-conical buildup with a peak around the main eruption vent. It is similar with the mud volcano models developed by Kholodov (1983) and Kopf (2002) where LUSI is classified as a swampy mud volcano type. The peak is not high due to the low viscosity of the extruding mud. 


\subsection{Forming of the Crater}

The series of photographs in figure 25 below represent the changes through time at the main vent of LUSI Mud Volcano. In a time span of 5 years, LUSI has evolved from a small eruption of steam, hot water and mud to a destructive high rate mud flow, engulfing houses, schools, factories, neighboring villages and caused a large-scale ground deformation, damaged the highways, railroad, pipelines, electrical power lines and others; to presently a much more calm low rate ejection of mud and fluid and occasional intermittent stopping of steam eruption. LUSI evolved through time from a localized kilometre-scale fault zone in 2006 and expanded through pre-existing NE-SW Watukosek fault zone pathways in 2010.

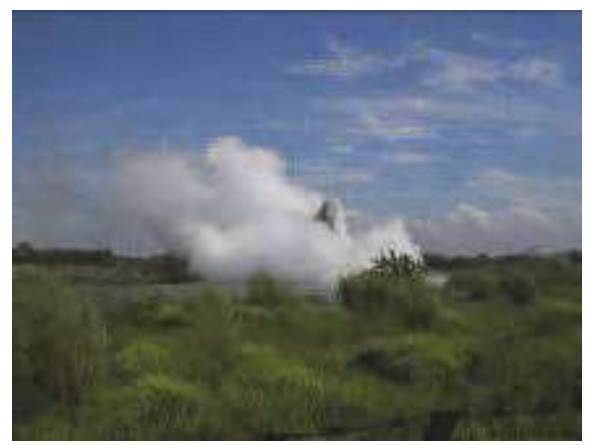

May 2006

LUSI mud volcano on its first day, May 29th, 2006. The mud eruption is approximately $200 \mathrm{~m}$ from the Banjarpanji-1 well location. Initial eruption in the form of mud and hot water and clouds of steam with a discharge rate of less than 5,000 $\mathrm{m}^{3} /$ day.

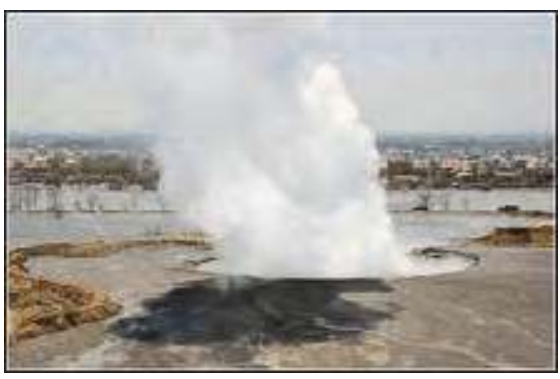

June 2006

In June, the crater had swelled and the discharge has reached approximately 50,000 $\mathrm{m} 3 /$ day, with water temperatures as high as $97^{\circ} \mathrm{C}$.

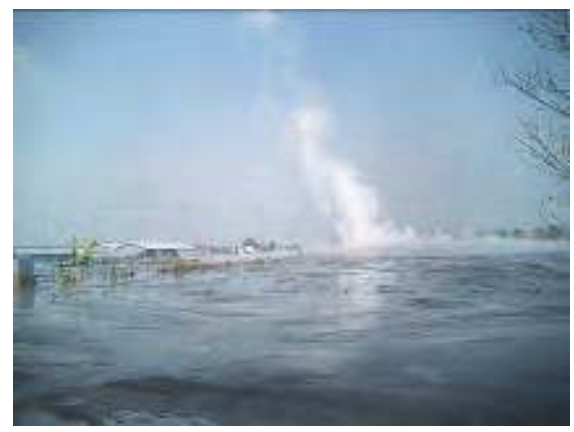

August 2006

A semi conical structure is starting to form. The volume of water in LUSI is very large reaching up to $70 \%$ of the total volume of mud, shown in the picture as water reflection. The low viscosity of the mud results in mud spreads across, extending to large areas instead of building up vertically. 

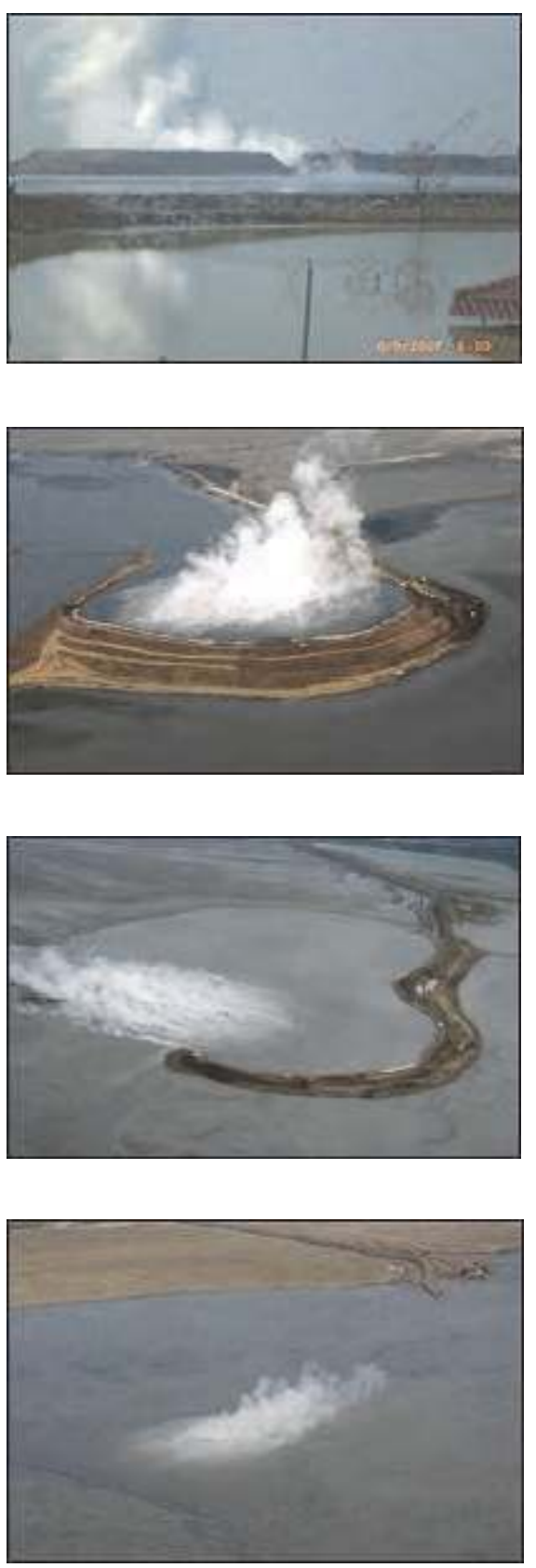

May 2007

In May 2007, retaining walls/dykes were built to prevent the mud from spilling over to the villages and major roads. The height of the dykes encircling the center of eruption reached approximately $15 \mathrm{~m}$. The average mud flow rate at the time was around $100,000 \mathrm{~m} 3 /$ day.

\section{May 2008}

Ring levees/dyke were rebuilt and raised to prevent overflow of mud into the closest villages. Discharge rate was still around $100,000 \mathrm{~m} 3$ / day with surface water temperatures remain constant at $97^{\circ} \mathrm{C}$.

\section{February 2009}

By February 2009, the ring dyke on the south and north sides are rapidly sinking due to subsidence and are difficult to maintain despite efforts to continuously pile with soil and gravel.

July 2009

The ring dyke around the main vent collapsed and sank in July 2009. The eruption discharge rate at this time is reduced by $60 \%$ to approximately 40,000 $\mathrm{m}^{3} /$ day. 

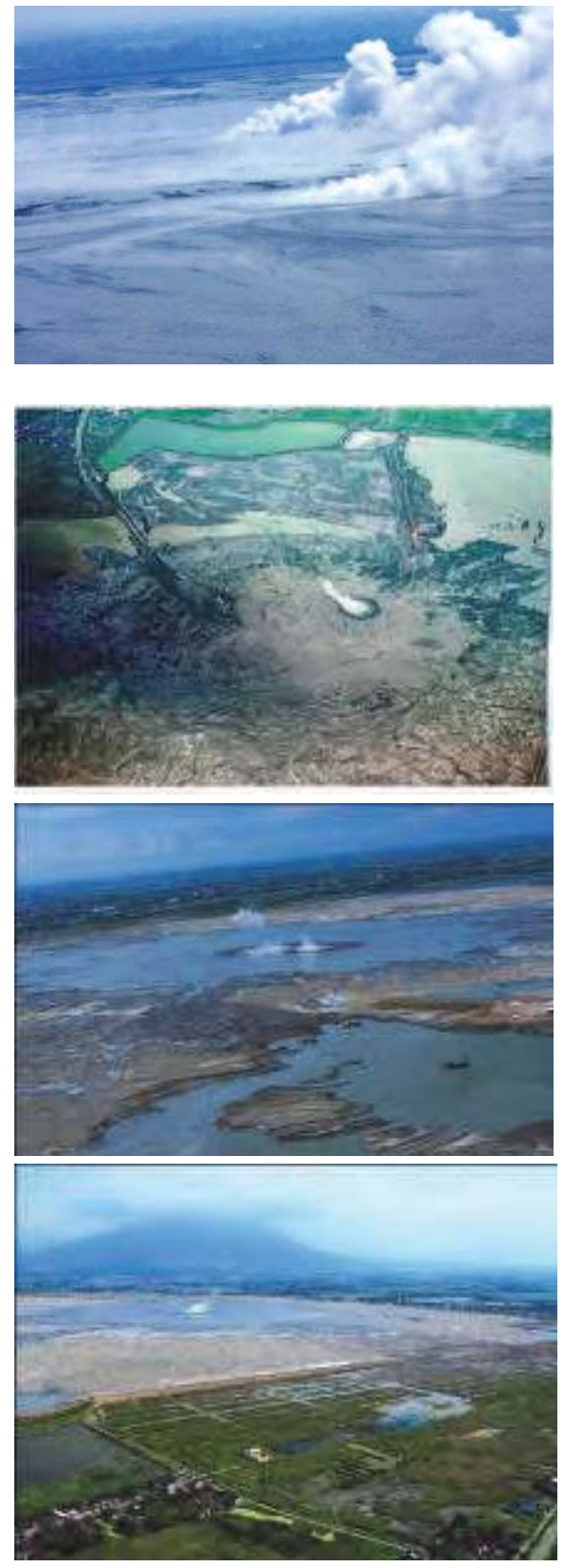

January 2010

The diameter of the main crater at this time is approximately $120 \mathrm{~m}$ and flowing continuously 30-50,000 m3/day. At times instead of a single crater, it changes to two or three points aligned in the direction of the Watukosek fault. The flow is mainly liquid and hot steam. A gently sloping cone is starting to form. The mud covered area is mostly wet, covering $80 \%$ of the total area.

January 2011

At this time the mud flow rates and the scale of steam clouds are reduced. The eruption rate has decreased to less than $10,000 \mathrm{~m} 3 /$ day. LUSI is now entering a new phase, from an eruptive one to a mature and quiescence phase. The mud around the main vent is solidifying forming a dome.

May 2011

The mud volcano viewed from the west side. Note the reduced scale of the clouds of steam.

\section{May 2011}

The mud volcano viewed from the north side with the Watukosek escarpment hills and Mt. Penanggungan in the background.

Fig. 25. Changes from time to time at the main vent of LUSI Mud Volcano 


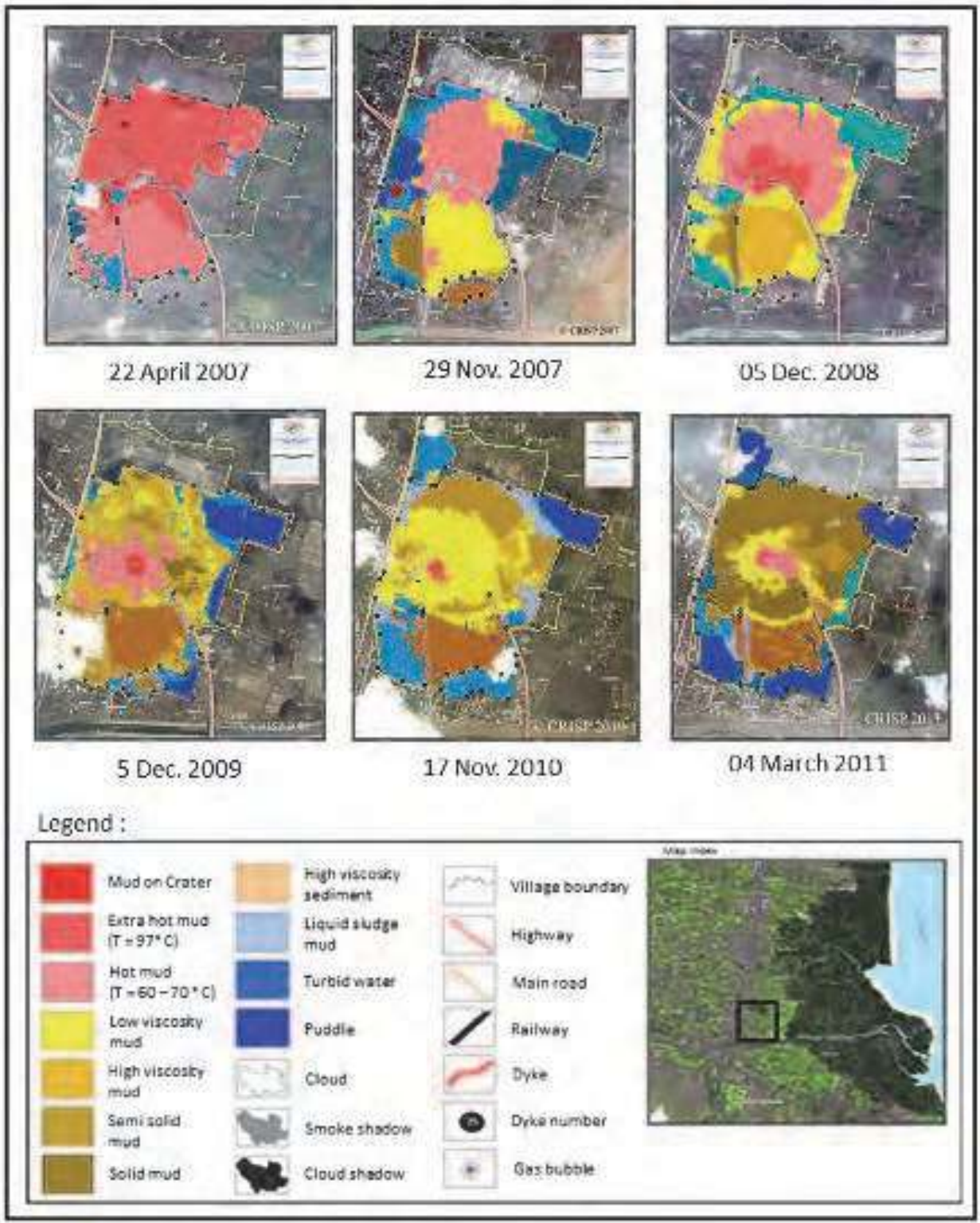

Fig. 26. Map interpretation of the results around the center of LUSI from IKONOS imagery using ERMAPPER Software from 2007 to 2011. The interpretation shows a decrease in the volume of hot mud around the main vent. In 2007, almost all the fluid inside the dyke is above $60^{\circ} \mathrm{C}$. By November 2007, the rate of hot mud has begun to diminish. A year later, in December 2008, the LUSI morphology dome has begun to form. The next phase was the reduced production of hot mud in the main vent and the heightened dome coupled with the formation of the patterns of mud and water flow in the vicinity. (source: BPLS 2011) 


\subsection{Morphological changes}

Spatial Aerial Photo Analysis was performed utilizing the CRISP satellite map regularly obtained from the Centre for Remote Imaging, Sensing and Processing, at the National University of Singapore (http://www.crisp.nus.edu.sg). Changes at the center of the eruption and the adjacent slopes can be observed.

The area of observation was between $-7^{\circ} 27^{\prime} 04^{\prime \prime} / 112^{\circ} 40^{\prime} 27^{\prime \prime}$ and $-7^{\circ} 35^{\prime} 52^{\prime \prime} / 112^{\circ} 49^{\prime} 35^{\prime \prime}$ an area of about $3.7 \mathrm{~km} \times 4.0 \mathrm{~km}$ or $14.9 \mathrm{~km}^{2}$, with the focus of the coverage area on the mud ponds.

The data processing stages were as follows:

1. Processed multitemporal IKONOS image data obtained from the CRISP in 2007 until 2010. ERMAPPER software was used for image enhancement, image correction, interpretation and image classification.

2. Spatial or geographical information analysis, information visualization, organization of information, combining thematic information using GIS software.

3. Classification of information based on the detection and identification of objects on the surface of the earth from a satellite image, to the next as the primary identifier elements and limits of an object is done by coloring.

\section{Geohazard}

The mud eruption in Sidoarjo has buried houses, villages, schools, factories, and displaced thousands of people and continues to pose a geohazard risks in a densely populated area with many activities and infrastructures. Studies of other mud volcanoes in East Java were used in the geohazard assessment.
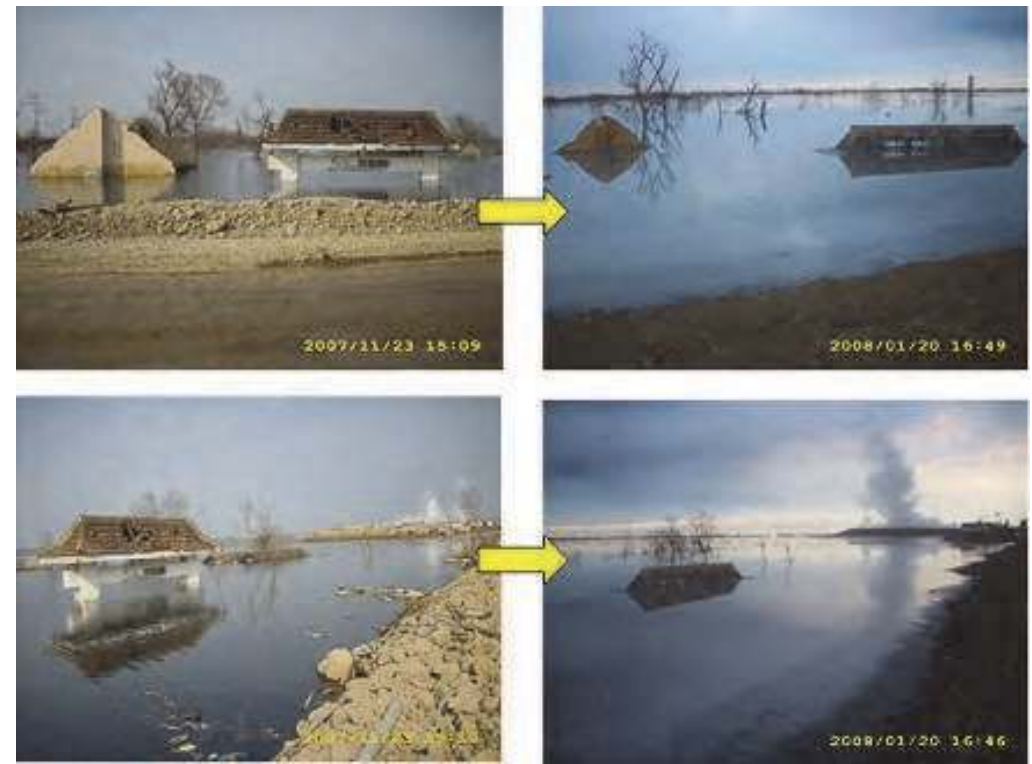

Fig. 27. Dramatical sinking of a village gate of Siring Timur, located to the west of the main vent. The gate and the rubble was half buried but still visible in the 23 November 2007 photograph. Two months later just a part of the tile roof and walls remain visible on 20 January 2008. 
LUSI initially had five mud eruption vents, but only one remains active. There is a possibility that inactive mud eruption vents may reactivate or new ones will emerge in other locations. The study suggests a possibility of mud erupting at one or more of the known gas bubble locations or at a new location along zones of weakness on reactivated pre-existing faults or on new fault zones. Methane gas bubbles have been identified in more than 220 locations, and are generally associated with fractures. Some are more active than others while some have died. In most cases, the methane is non-flammable because it is in such low concentrations from rapid dispersion in the air. However where bubbles are confined, the concentration of methane is high enough to burn. The gas leaks from these fractures suggest breach of seal and loss of sealing capacity of faults and the impervious shale overlying geological structures, in particular the flanks of Wunut anticline that contain gas accumulations.

The occurrence of gas bubbles also suggests that subsidence is not merely a shallow nearsurface phenomenon as a result of surface loading by the weight of the mud or soft soil layer compaction, but instead also affecting deep horizons as the gas comes from a deep source. Gas chromatography of sampled gas bubbles near the main eruption vent in July 2006 indicates it primarily consists of methane but the presence of some heavier gases in small quantities including ethane, propane, butane, and pentane suggest a deep thermogenic origin and long extended fractures.

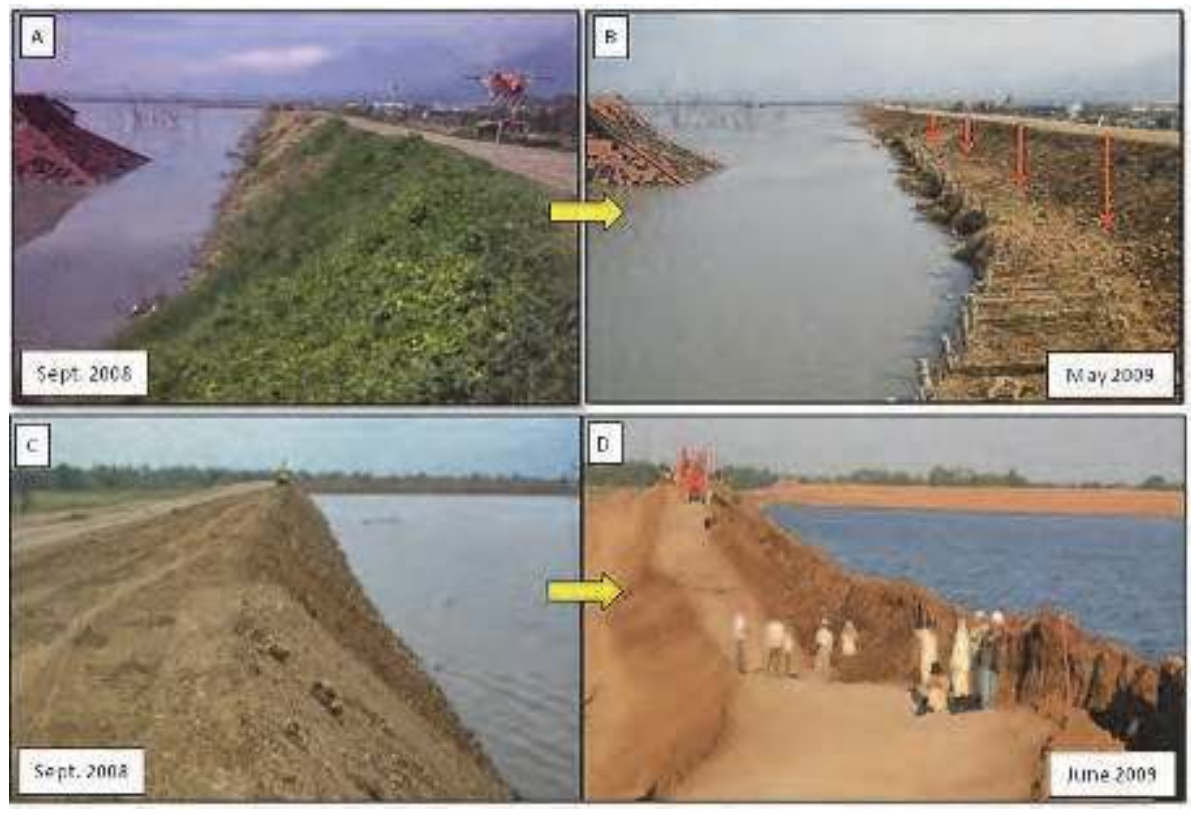

Fig. 28. (A)\&(B). Photos before and after the collapse of levees west of the main vent. The levee has decreased in height by approximately 1 meter along a $150 \mathrm{~m}$ interval. (C)\&(D). Photos before and after the collapse of the levee north of the main vent. The levee has decreased in height by $1.5 \mathrm{~m}$ along a $200 \mathrm{~m}$ interval. 


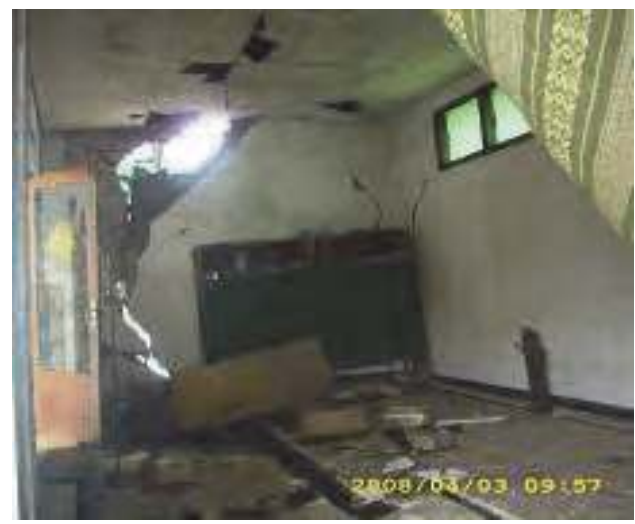

Fig. 29. A mosque located in the Renokenongo village, to the east main of the vent is damaged due to fault reactivation. At this location a lot of fractures were oriented NE-SW, and these are patterns of the Watukosek fault syatem.
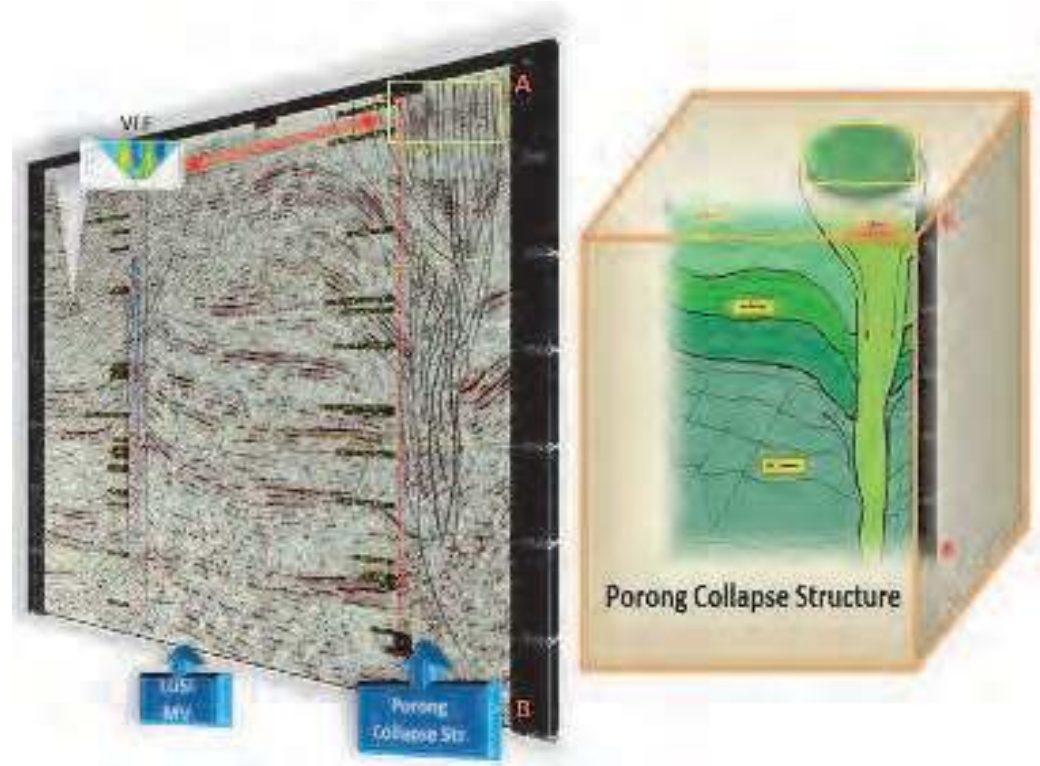

Porong Collapse Structure

Fig. 30. The Porong paleo collapse structure was used as an analogy to predict the deformation pattern that will occur in LUSI. VLF measurement results indicate the existence of patterns of subsidence on the surface which is indicative of the onset of collapse

In terms of geohazard risks, the evidence and areas of concern include i) rupture of gas and water pipelines (shear and subsidence); ii) railroad bending (shear/faulting and subsidence); iii) road cracks (subsidence); iv) relief wells casing integrity (subsidence and shear); v) dyke collapse (subsidence); v) gas bubbles which appear along fractures and zones of weakness (shear/faulting and subsidence). (Istadi et al. 2009). 
LUSI's continuing subsidence forms a depression bowl or funnel shaped structure. The subsidence forms an accommodation space, a natural basin to contain the mud. However, the high water content of the mud means it has a low viscosity and therefore cannot accumulate vertically to form a high and steep mountain-like structure. The mud, in particular the separated water tends to spread sideways which increases pressure on the mud retaining dykes that collapsed on a number of occasions and caused flooding. If the mud eruption continues with a high rate, then the potential flood prone areas will expand. The accumulated water at the peripheries away from the main eruption, which are held by the retaining dykes exert increasing hydrostatic pressure on the dyke walls. This increases the risk of retaining dyke failures.

Attempts to stop the mud flow should be implemented only after the likely causes of LUSI are studied and explained. The other alternative is to let nature find its own equilibrium and take care of itself, as LUSI mud volcano appears to be the result of a natural phenomena.

\section{Other Mud volcanoes in East Java}

Mud volcanoes are common in the northern part of Java and Madura Island (Satyana, 2008). Like elsewhere in the world, mud volcanoes in Java and Madura typically are located at the top of anticlines or along faults in the area. This phenomenon is demonstrated by the Sangiran mud volcano which is located at the top of the truncated dome on an up-thrown fault block, while the Bleduk Kuwu mud volcano is located on the top of the Purwodadi anticline, The Api Kayangan (means Fire of Heaven, or Eternal Fire) mud volcano is at the top of the Bojonegoro anticline. The Pengangson mud volcano located at the top of the Kedungwaru anticline, while the Pulungan and Kalang Anyar mud volcanoes are on the top of the Pulungan anticline. The Gunung Anyar (means New mountain) mud volcano is at the top of the Guyangan anticline, Bujel Tasek (Madura) and finally LUSI erupted on the extension of the Sekarputih anticlinal structure. Most of the mud volcanoes in East Java, with the exception of LUSI, are in the relative quiescence period and some can be considered in the dormant period with minimal activity. The existence of these mud volcanoes are described in the latter part of the paper

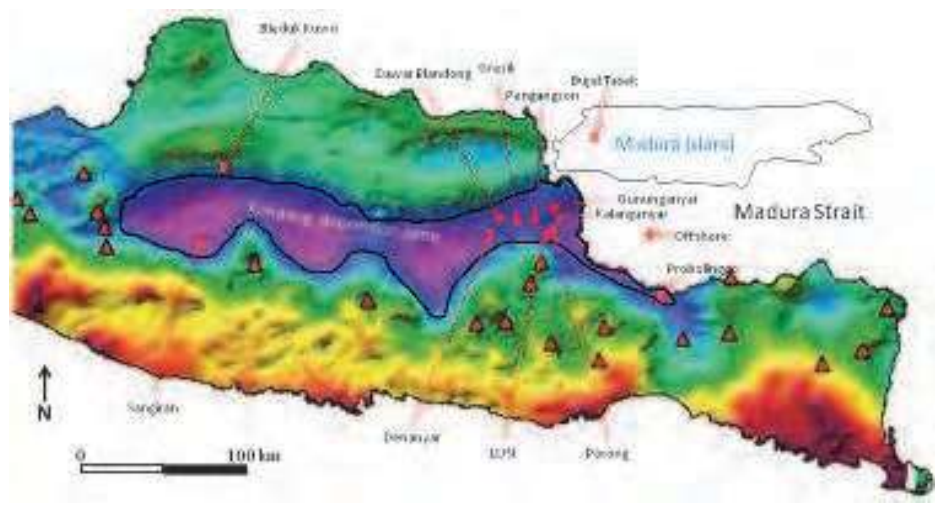

Fig. 31. Gravity map of East Java showing East Java Basin's depositional centers (blue) in the Kendeng depression zone. Red dots are the identified mud volcanoes, while the triangles are magmatic volcano locations. 
The presence of mud volcanoes in the northern East Java Basin, especially along the Kendeng depression zone, is a common phenomenon. Their presence reflect the overpressure condition due to the very rapid deposition of the bluish-green mudstone and marlstone of the Sonde Formation during the Pliocene in a back arc basin setting that is folded and faulted (Dickinson, 1974).

In Central and East Java mud volcanoes are found within the Kendeng depression zone, except Bujel Tasek which appears in Rembang zone. The Kalang Anyar, Gunung Anyar, Pulungan, Bujel Tasek (Madura) and LUSI are in a straight line trending NE-SW contiguous with the regional fault trend, originating from the crater of Mt Penanggungan of the Arjuno-Welirang volcanic complex, following the Watukosek fault escarpment in the southern mountain ranges northward to Bujel Tasek in Madura island (see figure 32).

\subsection{Kalanganyar}

Kalanganyar mud volcano is located approximately $3 \mathrm{~km}$ south of Juanda Airport and approximately $15 \mathrm{~km}$ North-East of LUSI. The phenomenon of mud volcanoes in this area has been identified and mapped on the 1936 geological map of the Dutch era, suggesting it was formed long before the 1936 Duyfjes map. A temple known as Candi Tawangalun Majapahit (approximately 500 years ago) situated on the northern edge of the mud volcano suggest the significance of the mud volcano in the Majapahit era (see figure 33). Interestingly, some parts of the temple's material were made from material products of the Kalanganyar mud volcano.

The morphology of the Kalanganyar mud volcano forms a low relief hill overlying the alluvial plain deposit. The dimension of the main eruption cone is around $12 \times 18 \mathrm{~m}$. Some activities are still evident such as gas bubbles and some fresh mud around the main eruption vent (see figure 34) with a temperature of $\pm 38^{\circ} \mathrm{C}$. The unit is composed of siltsized material and grains of fine sand and clay and saltwater that forms salt deposits.

The low relief of the mud volcano suggests that the mud has very low viscosity. The mud shrinks during dry season to form dessicated mud crack structures that are commonly found in the area. The mud material is derived from older rocks than the surrounding alluvial plains, correlatable with the mud at LUSI, the Upper Kalibeng Formation of PlioPleistocene age.

In the area around the active gas bubbles, rock fragments, such as siderite and salt deposits, are always found. The gas bursts are typically mild consisting of mixed gas, and formation fluids mainly connate water. Microbial activites are also found near the gas bubbles.

Mud breccias that are ejected from the Kalanganyar mud volcano are in the form of mud supported mudstone fragments which are light brown in color, composed of abundant carbonate mud, and quartz with opaque minerals in small quantities. Rudstone (Embry and Klovan, 1971) which is gray - brownish gray, grain supported, with fragment components consisting of shells of molluscs (Gastropoda and Pelecypoda, with a dominance of Ostrea shells) measuring $10-20 \mathrm{~cm}$ are abundant $(>10 \%)$ and bound by the matrix and carbonate cement (Figure $35 \mathrm{~A} \& \mathrm{~B})$. Balanus fossils were largely found freed from the carbonate (Figure $35 \mathrm{C}$ ) although some were still found to be bound by carbonate cement.

The mud eruption carried younger sediments and boulders which contain mud breccias and limestones. The stratigraphic position of the mud breccia based on Balanus fossil found on limestone within the mud breccia, indicate that this was sourced from the Sonde Formation of Pliocene age. The existence of mollusc and balanus contained in rudstone limestones suggest deposition in a shallow marine environment to the coastal littoral zone with strong 


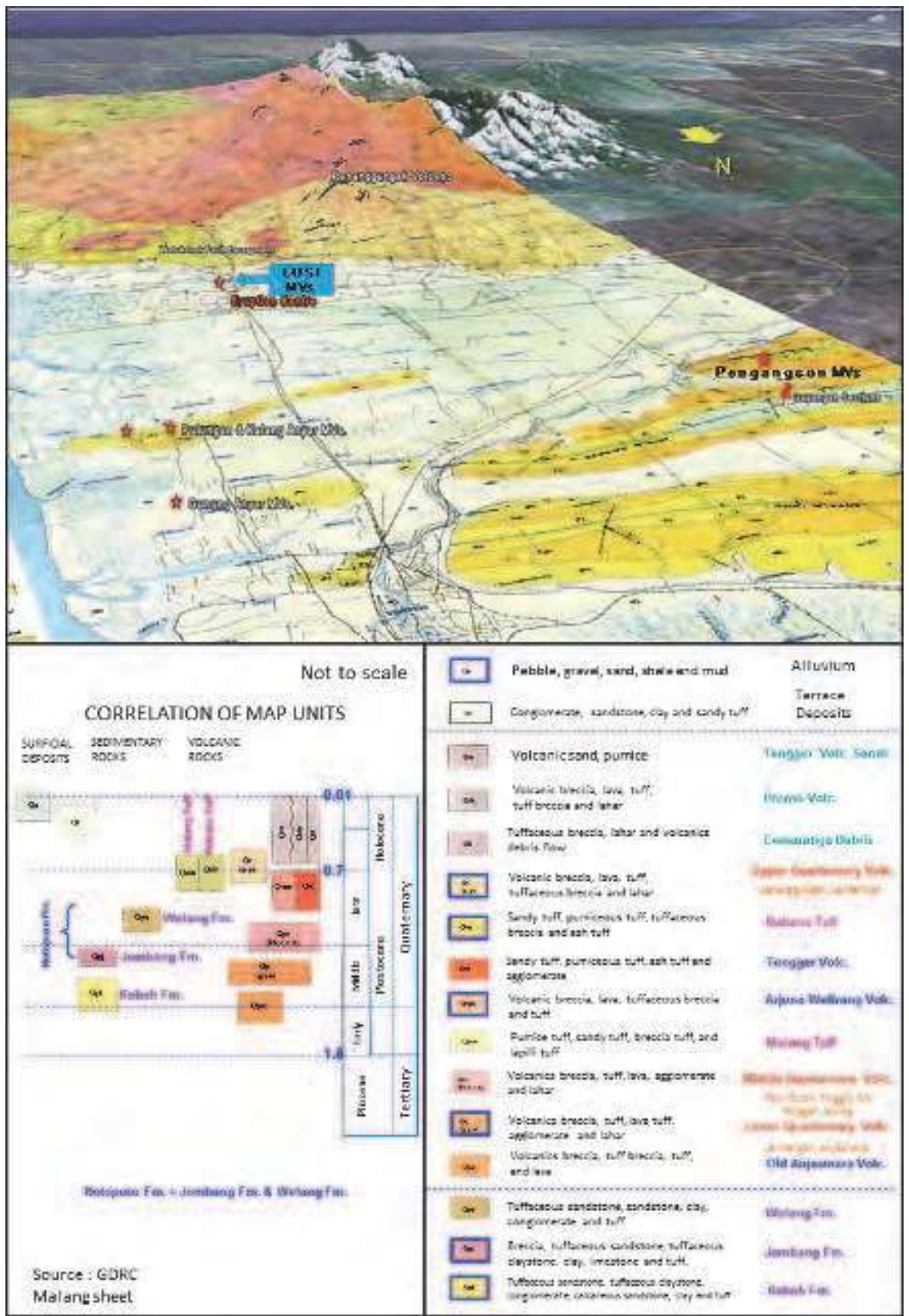

Fig. 32. Geological map overlaid with Google earth. Red stars are the identified mud volcano locations. The mud volcanoes are located across the top of anticlines and form a lineament. 


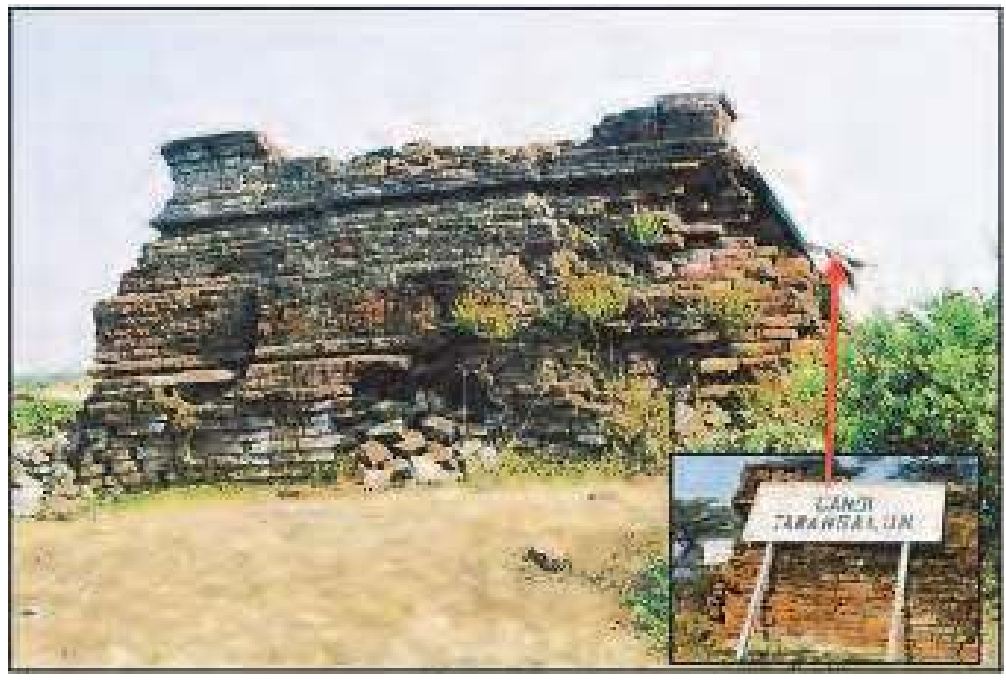

Fig. 33. Tawangalun temple was built during the Hindu kingdom (500 years ago) situated in the Northern edge of Kalanganyar mud volcano. Some materials of the temple were made from fragments from the Kalanganyar mud volcano.

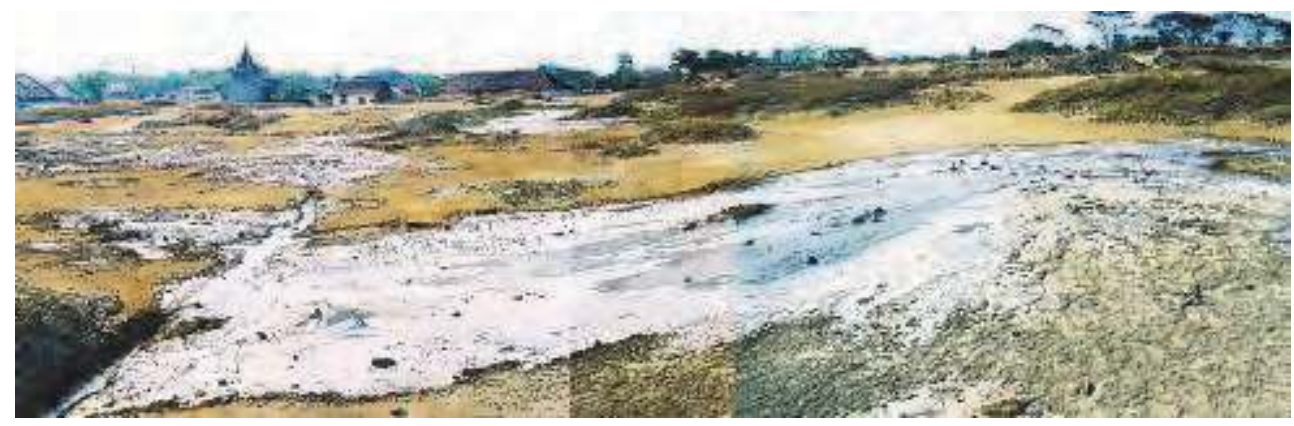

Fig. 34. Kalang Anyar mud volcano in Kalanganyar village, Sidoarjo, East Java

energy currents. The dominant grain supported matrix of rudstone further suggests a high energy depositional environment. A shallow marine environment is located on the continental shelf with the fore reef sea conditions that are less affected by the supply of silisiclastics. The existence of mudstone with mud supported textures indicate deposition below wave base conditions on the back reef, rocks consequently do not experience the washing process (winnowing) by wave activity. The older mud volcano material is thought to have been sourced from the deeper Upper Miocene Kalibeng Formation, suggesting a regressive sequence in this part of the Kendeng zone of the East Java Basin. 

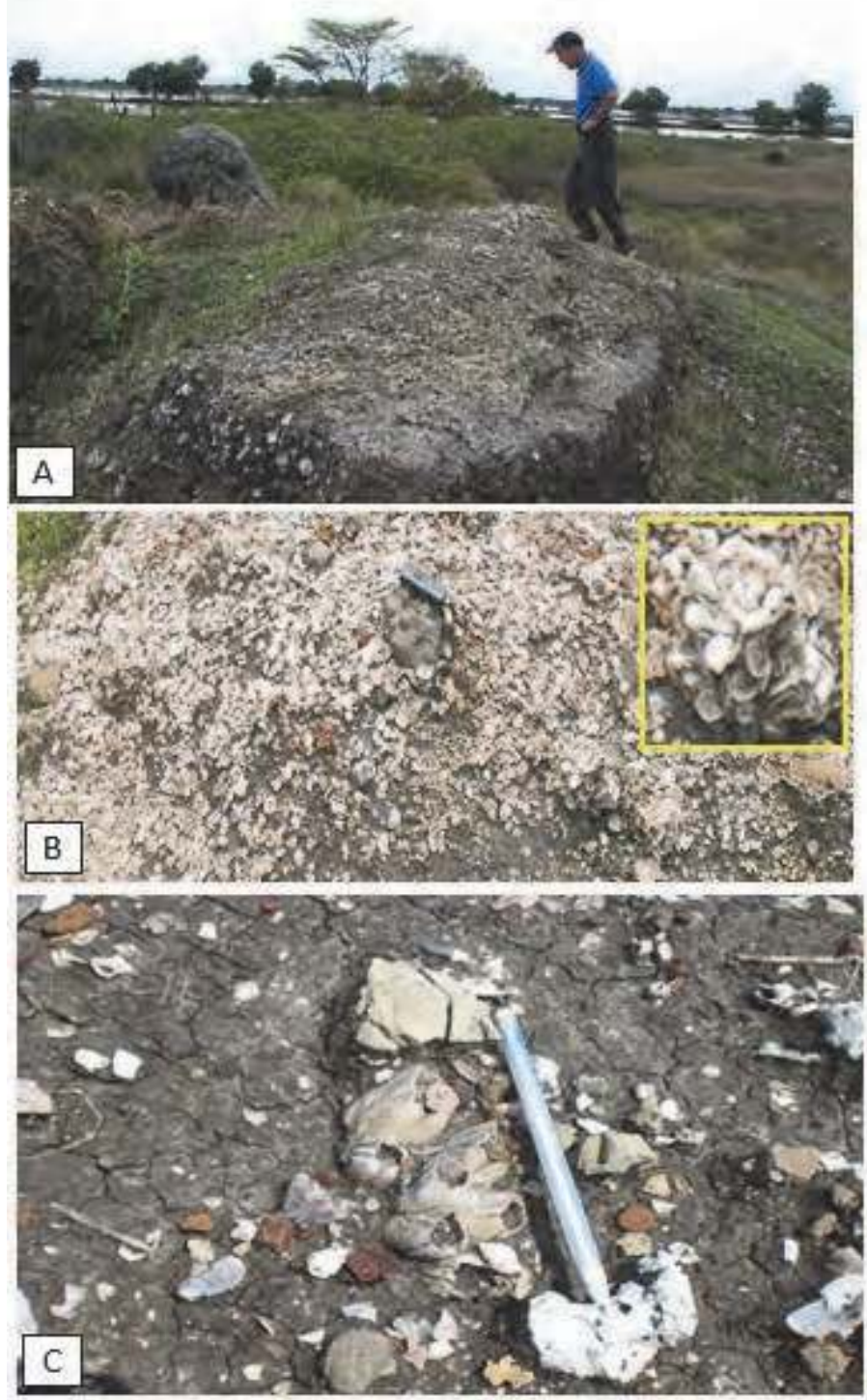

Fig. 35. (A)\&(B) Sandstone with mollusc shells dominated by Ostrea , (C). Balanus fossils among carbonates and siderite.

\subsection{Gunung Anyar}

The Gunung Anyar mud volcano (means "new mountain") is located $8 \mathrm{~km}$ to the westnorthwest of Kalang Anyar mud volcano and is surrounded by densely populated residential area in the Gununganyar village, Surabaya. The morphology of the Gunung Anyar mud volcano is a northeast orientation and elongated hill-shaped geometry on the 
surrounding flat alluvial plains. The dimension of the still active main eruption vent is approximately $8 \times 9 \mathrm{~m}$. The ejected material is composed of silt-sized grains of predominantly fine sand and saltwater. The temperature of the vent is $\pm 37.2^{\circ} \mathrm{C}$. More solid content than fluid has erupted from this mud volcano.

The lithology is similar to Kalang Anyar mud volcano where the composition is predominantly silt with the physical characteristics of brownish-grey, fine sand-sized to clay. In dry conditions, the structure shrinks, typically forming desiccated mud cracks. Seepage of crude oil of black color is also visible among the small bubbles that are still active.

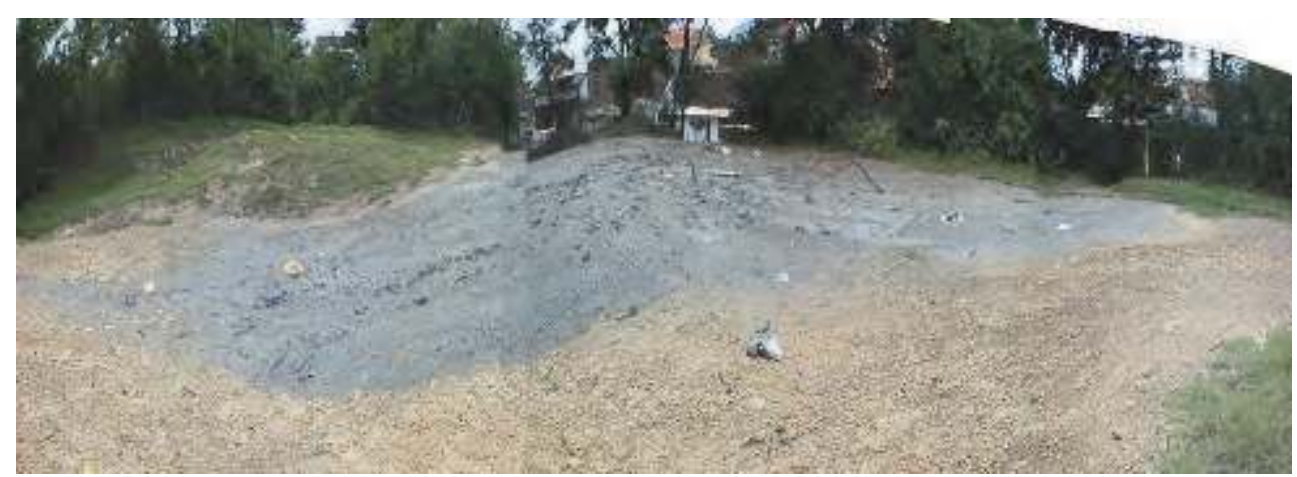

Fig. 36. Gunung Anyar Mud Volcano morphology at Gunung Anyar Village in the Southern part of Surabaya, East Java.

Based on rocks and fragments carried by the mud eruption, the erupted materials were sourced from the following stratigraphic layers:

a. Marl

Brown marl with some weathered surfaces, white in color, with clay-sized fossil planktonic foraminifera and sand-sized bentonic fragments. Fresh outcrops of limestone fragments that appear to be newly ejected by the mud volcano. Stratigraphic position of the marl based on the physical properties and fossil content, indicate that this was derived from the Kalibeng and Sonde Formations.

\section{b. Limestone}

The limestone contains balanus fossils bounded by carbonate cement. The limestone based on fossil is thought to have been sourced from the Sonde Formation. The presence of balanus fossils typically suggest the coastal litoral zone depositional environment with the strong currents, while the texture of the limestone, suggest the low - moderate flow of energy environment with warm, calm and shallow waters possibly positioned on the back reef.

\section{c. Calcareous sandstone}

Weathered brown sandstone, poorly sorted, sub-rounded, fine sand-sized, composed of quartz, feldspar, biotite, and calcite. Black mudstone associated with these calcareous sandstones is also found in small quantities. The sandstone may have been sourced from the Pucangan Formation, Pleistocene in age. 


\section{d. Molluscs sandstone (grenzbank)}

Sandstone containing molluscs of freshwater and seawater were found in this location. The freshwater molluscs which are characterized by the thin shell bi-valves are more dominant than the seawater molluscs. The presence of mixed seawater and freshwater molluscs suggest shallow to transitional marine deposition environment.

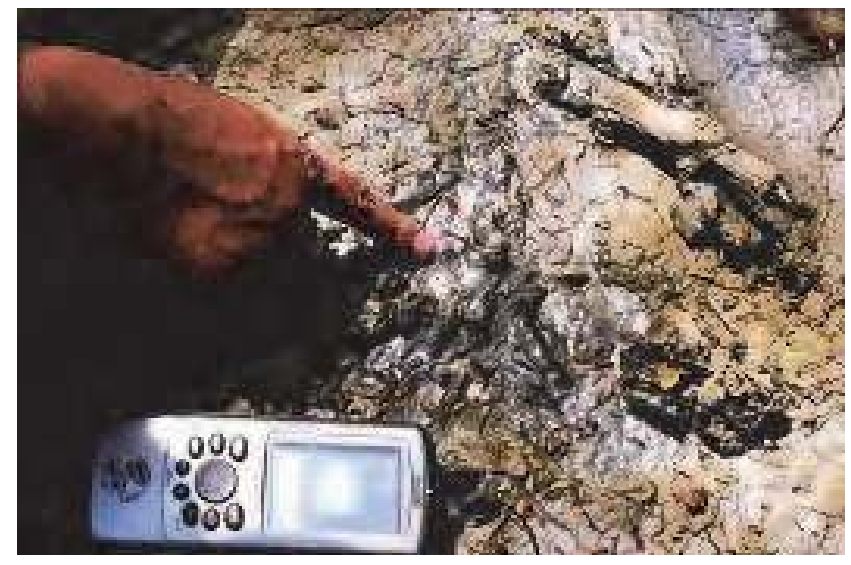

Fig. 37. Crude oil seepage coming out with salty connate water along with bubbles in Gunung Anyar Village.

\section{e. Silt}

Silt makes up most of the mud volcanic area. It is composed of silt-sized grains of predominantly silisiclastic brownish-grey colored clay materials and the salt water. The temperature is around $37^{\circ} \mathrm{C}$ at the mud conduit. The mud contains more solid silt and clay materials than fluid. Silts were derived from underlying older rocks of possibly Upper Kalibeng Formation of late Miocene. The presence of rock fragments, siderite, and seepage of black crude oil are almost always found within the vicinity of active bubbles.

\subsection{Pengangson}

The location of Pengangson mud volcano is in the village of Kepuhklagen, Wringinanom, Gresik Regency. Compared to other mud volcanoes in East Java, the Pengangson mud volcano is the most ideal example of a mud volcano. The younger sediments outcropped and exposed at nearby excavated cliffs to the west of the mud volcano, and older rocks are found as fragments or clast carried by the mud volcano eruption. The geological structural components at this site are also clearly visible, such as folds, fractures, fault lines and sedimentary structures.

The morphology is formed of low hills between the alluvial plain surrounding. The unit is composed of silt sediment material with dominant clay-sized grains. The low temperature mud of $\pm 39.5^{\circ} \mathrm{C}$ is typical of other mud volcanoes in other parts of East Java. The mud is thick and the liquid consists of a mix of formation fluid, crude oil seeps, salt deposits and gas bubbles. 


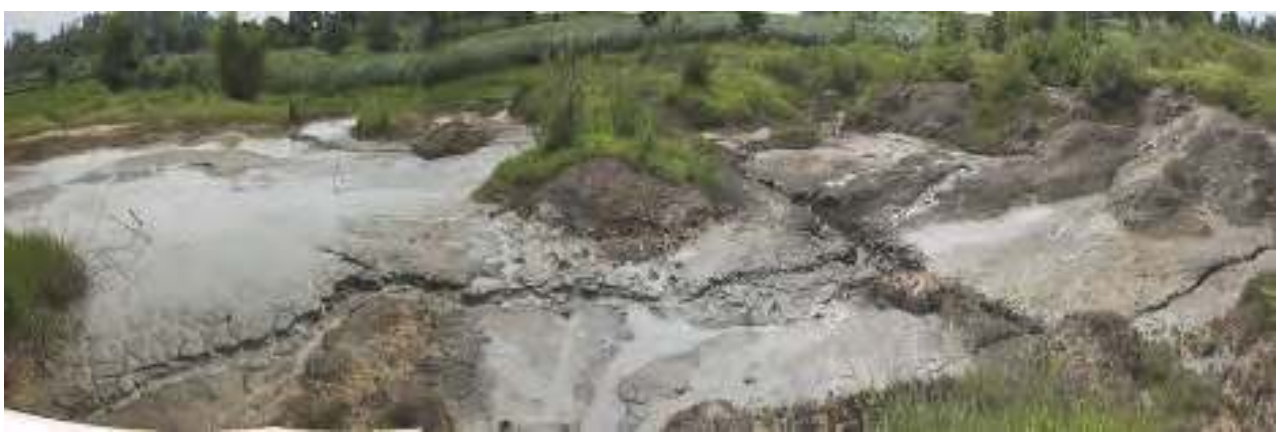

Fig. 38. Pengangson Mud Volcano in Kepuhklagen village, Gresik, East Java

The materials ejected by the mud volcano are the following:

\section{a. Sandy Mudstone - Sandy Siltstone}

Rock outcrops are generally brownish-grey in fresh and partially weathered condition. Physical characteristics of the rock suggest that it is from the Sonde Formation. Based on the deposition enviroment, lithology, sedimentary structure, texture, mineralogical composition, and fossils suggest that this unit was deposited in a middle shelf environment - lower delta plain.

\section{b. Tuffaceous Sandstone unit, Sonde Formation}

The naming of the sandstone unit is based on the condition of the rock outcrop on the cliffs with tuffaceous sandstone lithology that shows the layered structure and planar crossbed. Rock samples in this unit do not contain foraminifera because of the dominance of volcanic material in the rocks.

The composition of the constituent material of plagioclase and the presence of volcanic glass which tends to be wacke, suggests that the source is not far from the sedimentation basin. The similarity of physical properties, and texture of rocks suggest this unit is part of the Sonde Formation.

\section{c. Sandstone unit, Pucangan Formation}

This unit is characterized by the presence of sedimentary structures such as grading, parallel lamination and slump structures. Outcrops of fresh rocks generally show somewhat weathered condition. The bottom of the unit is dominated by volcanic sandstone that contains calcareous mudstone layers. This unit is part of an eroded top of anticline.

Interpretation of the environment based on the lithology data, sedimentary structure, texture, mineralogical composition, and fossils indicates that this unit was deposited on the inner shelf environment - lower delta plain with traction and suspension flow mechanism. The sequence of lithologies indicates deposition in increasingly shallow conditions with the initial deposition on the inner shelf. The similarity of physical properties, texture, structure, age and environment of deposition of rocks suggests that this unit is part of the Pucangan Formation.

\section{d. Tuffaceous Mudstone}

The outcrop of rocks is generally fresh or slightly weathered. Overall this unit is dominated by massive mudstone and tuff. The bedding trends west - east and slopes to the north and south. Interpretation of the environment of deposition based on the lithology, texture, and 
mineralogical composition is that this unit was deposited in a braided stream environment or sub flood plain and stream sediment was transported through the mechanism of suspension. The similarity of physical properties and the texture of rocks suggests that this unit is part of the Kabuh Formation.

\section{e. Volcanic sandstone}

This unit is characterized by the presence of sedimentary structures such as grading, crosslamination and parallel lamination. The outcrop of rocks generally show a somewhat weathered condition but rock structure is still visible. Interpretation of the environment of deposition based on the lithology, sedimentary structure, texture, and mineralogical composition suggests that this unit was deposited in a braided stream environment (minor channel) with traction flow mechanism. The similarity of physical properties, texture and structure of rocks suggests that this unit is part of the Kabuh Formation.

\section{f. Silt unit}

The naming of this rock unit is based upon the existence of a silt dominated mud volcano. The morphology of mud volcanoes forms a low hill between the alluvial plains. The unit is composed of silt sediment material dominant by clay-sized grains with a temperature $39.5^{\circ}$ C. From the main vent fluid, gas bubbles and salty water are released.

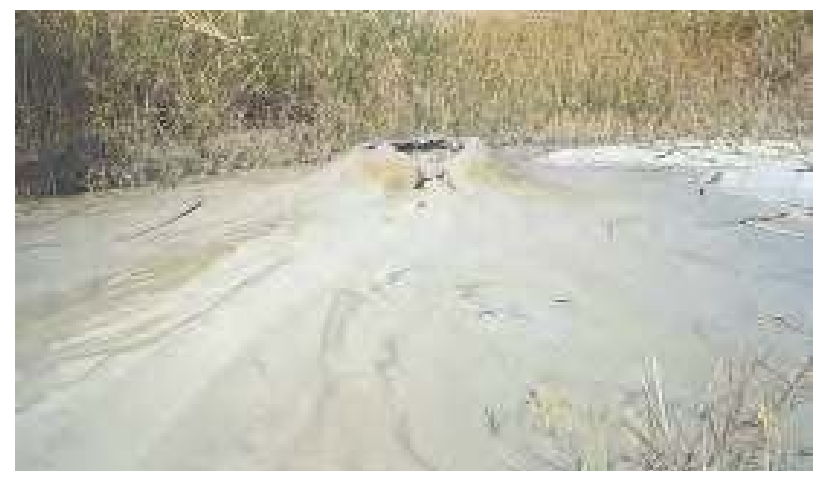

Fig. 39. Crude oil seepage, brownish-black in color together with mud and gas that comes out of a gryphon.

In the vicinity, bubble-shaped Gryphons, siderite, and salt deposits are commonly found (see figure 39). Rock fragments are found in a limited number that consist of calcarenite (Sandy micrite), calcareous sandstone, calcareous mudstone (Micritic mudrock in the Mount, 1985) and sandstones with molluscs.

This mud deposit in Wringinanom contains foraminifera planktonic fossils suggesting a middle Pliocene age to late Pliocene (N20-N21) mud source, while the content of bentonic neritic foraminifera suggests the bathymetry position in the middle neritic.

\subsection{Bujel Tasek}

Bujel Tasek mud volcano is found in the Katol Barat village, Bangkalan district of Madura island. The morphology of the Bujel Tasek mud volcano is very different from other mud volcanoes in East Java. The shape is a cone edifice with a height of approximately $12 \mathrm{~m}$ with a diameter of approximately $5 \mathrm{~m}$. The material that came out is a mixture of viscous mud, 
water and gas with a highly viscous mud. This cone shape is actually a giant gryphon formed by the high viscosity mud of a larger mud volcano that covers the area. Nearby this conic structure is a mud lake that represents an ancient mud caldera with mud conduits that are no longer active (see figure 40).

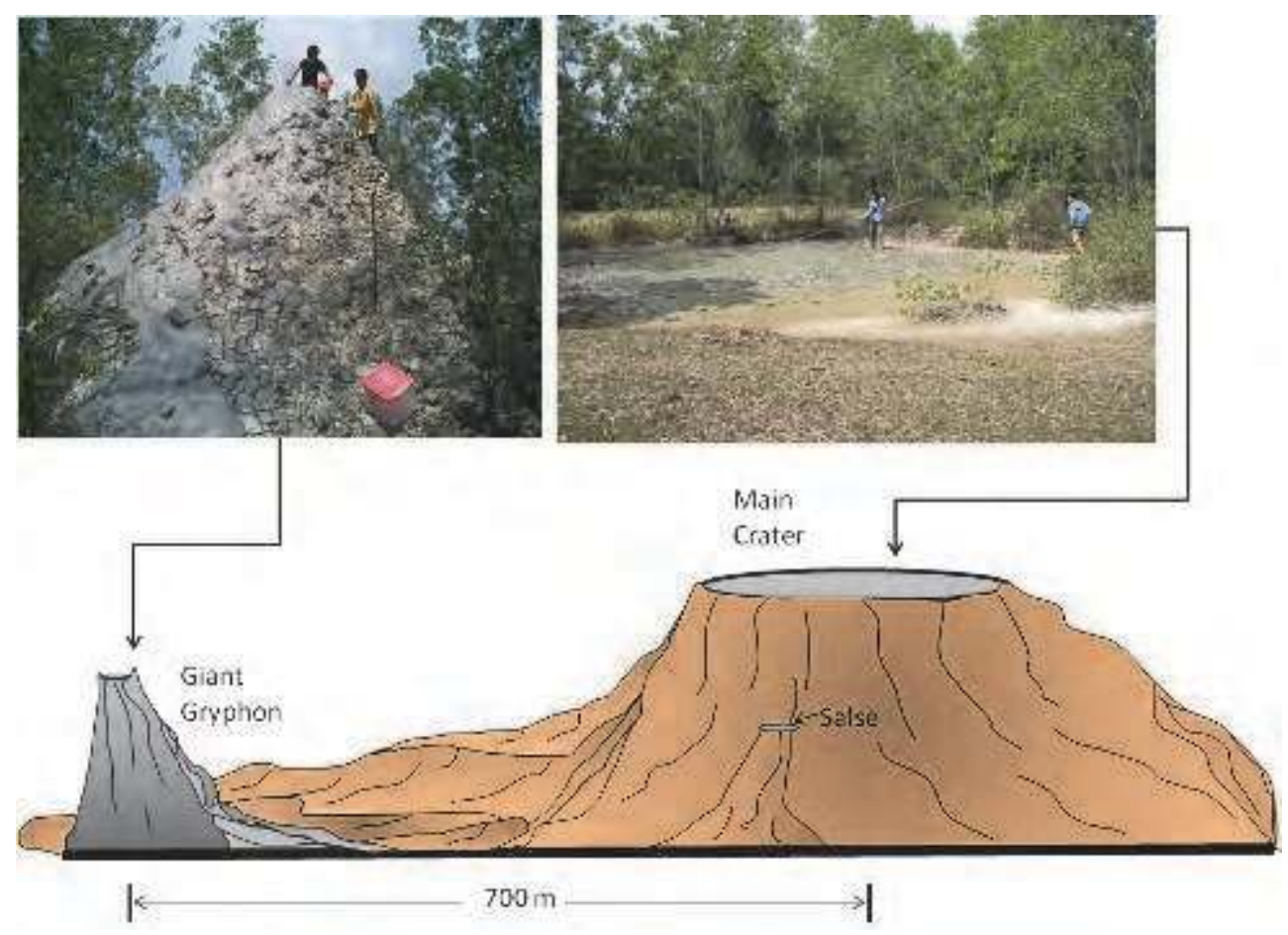

Fig. 40. Bujel Tasek mud volcano forms a cone morphology in the village of Katol Barat, Bangkalan, Madura island, East Java.

The mud sediment that came from the Lidah formation is characterized by its brownishgrey, fine clay. The mud breccia found is gravel to boulder sized, very abundant, with fragments ejected in the form of mudstone, calcareous sandstone, siderite and calcite.

The reddish-brown and gravel- pebble sized siderite mineral is found exposed. It is widely distributed, from the mud volcano to the valley. In addition, calcite is trapped in sandstones that fills the pores of the wood that look like silisified wood.

\subsection{Bleduk Kuwu}

This mud volcano is located in the Village Kuwu, Kradenan, Grobogan district, approximately $20 \mathrm{~km}$ south of Purwodadi in Central Java. The object of interest in Bleduk is the mud flow containing gas and salty water that takes place almost continuously in an area with a diameter of approximately $650 \mathrm{~m}$ (see figure 41). Etymologically, the name comes from Kuwu Bleduk. In the Javanese language 'Bleduk' means 'blast/burst' and 'kuwu' is derived from the word 'kuwur' which means 'run/scramble'. 


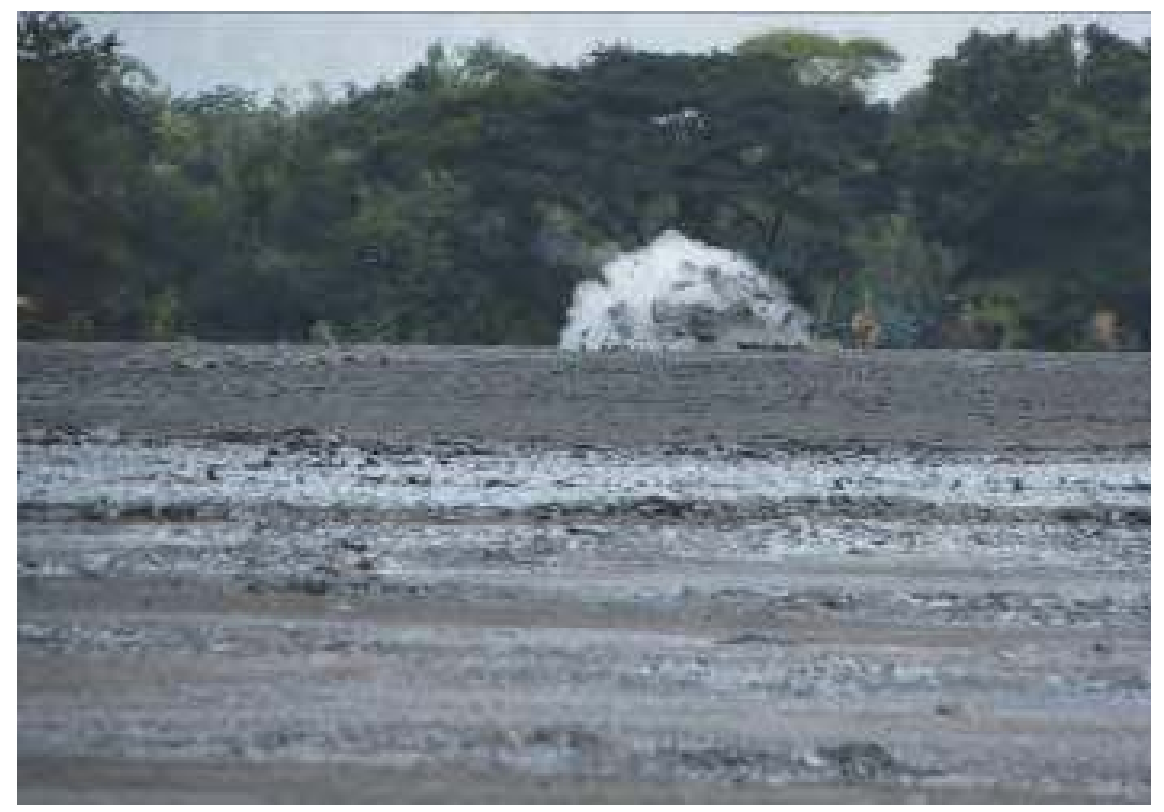

Fig. 41. Bleduk Kuwu mud volcano during its almost continuous eruption. The gas is flammable and sometimes self-ignites. The expelled water is commercially used to extract salt. Eruptions generally occur four or five times a minute, as a burst of warm mud and gas.

The Kuwu mud volcano cluster covers about 45 hectares. The biggest vent can erupt materials as high as 5 meters with expelled mud in a diameter of about 9 meters. At the main Kuwu site the mud volcano usually erupts four or five times a minute consisting of mud accompanied by the release of gas and water (sometimes oil). Often the eruptions are accompanied by an explosion as the gas self-ignites. The temperature of the mud ranges from $28-30^{\circ} \mathrm{C}$, while the smaller mud volcano is slightly cooler.

Bleduk Kuwu is surrounded by other mud volcanoes within a radius of approximately 1-2 $\mathrm{km}$ to the southwest, northeast and south with varying dimensional extents. To the southwest is Cangkring Bleduk mud volcano that occupies a larger area than the Bleduk Kuwu, while to the south is the Bleduk Banjarsari mud volcano, and to the East is Bleduk Crewek, and to the northeast is Medang Kamolan (figure 42). Other minor mud volcanoes in the area include Bledug Kesongo and Bledug Kropak. Geologically, these mud volcanoes are located at the boundary between North Serayu and Kendeng Depressions. Seismic sections across these mud volcanoes show disturbed zones from the top of the Kujung Formation, the top of Wonocolo Formation to the surface. The Bledug Kuwu disturbed zone is a chaotic mixture of upward convex and concave reflectors. Bledug Kesongo is characterized by a collapsed structure with upward concave horizons along the disturbed zone indicating a subsidence. The lower part of Late Miocene Wonocolo shales is believed to be the source of mud based on its fossil content. Seismic sections, however, show that the source of mud may also come from Early Miocene Tuban shales. Some diapirs also occur in this area and they are generally below the top of Wonocolo Formation. Folds in this area are considered to form diapirs as suggested by some seismic sections (Satyana and Asnidar, 2008). 


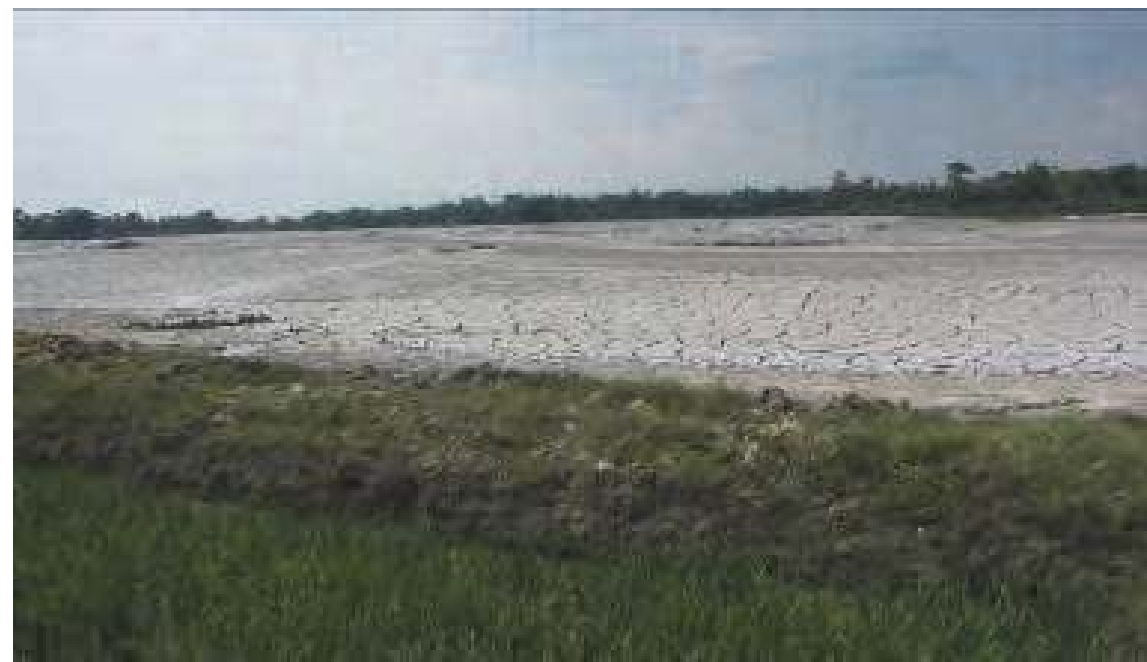

Fig. 42. Medang Kamolan mud volcano, located approximately $3 \mathrm{~km}$ northeast of Bleduk Kuwu mud volcano.

\subsection{Offshore mud volcanoes}

The existence of submarine mud volcanoes and mud diapirs in the Madura Strait, offshore areas of East Java is visible in the seismic profiles. The cross sectional appearance looks like an upwards dipping strata around a venting system of seafloor-piercing shale diapir cutting the overlying sediment and forming a conic volcanic edifice (see figure 43).

The Madura Strait is an offshore extension of the Kendeng Depression. Thick Pliocene to Pleistocene sediments were deposited rapidly and compressed elisional system in the Madura Strait depression. Deepwater sedimentation is still taking place in this portion of the Kendeng zone, and it has not been uplifted. In the Madura Strait area, east-west trending left lateral wrench faulting triggered mobilization of Miocene basinal shales during the Plio-Pleistocene, resulting in a series of shale diapirs. Further south, the impact of ongoing subduction along the Java Trench becomes increasingly significant and structures are dominated by north-directed thrusting, which may be independent of basement faulting (Satyana and Asnidar, 2008).

On the basis of structural style and the tectonic events, Widjonarko (1990) divided the Madura Strait block into five structural domains: wrench domain, slide domain, western basinal domain, eastern basinal domain, and southeastern fault block domain. Wrench and slide domains bound the Madura Strait to the Madura-Kangean High in the north. Southeastern fault block becomes the southern border of offshore Madura Strait. The main parts of the Madura Strait where mud diapirs and volcanoes exist are composed by western and eastern basinal domains. The Madura Strait Depression or Sub-Basin is one of the two deepest and thickest basins in Indonesia. In western basinal domain, very rapid sedimentation since the Late Miocene time resulted in the development of more than 3000 meters of Plio-Peistocene section. Eastern basinal domain is similar to western domain, the only difference is that the eastern basinal domain began to subside in the late Oligocene early Miocene, much earlier than the western domain (Satyana and Asnidar, 2008). 

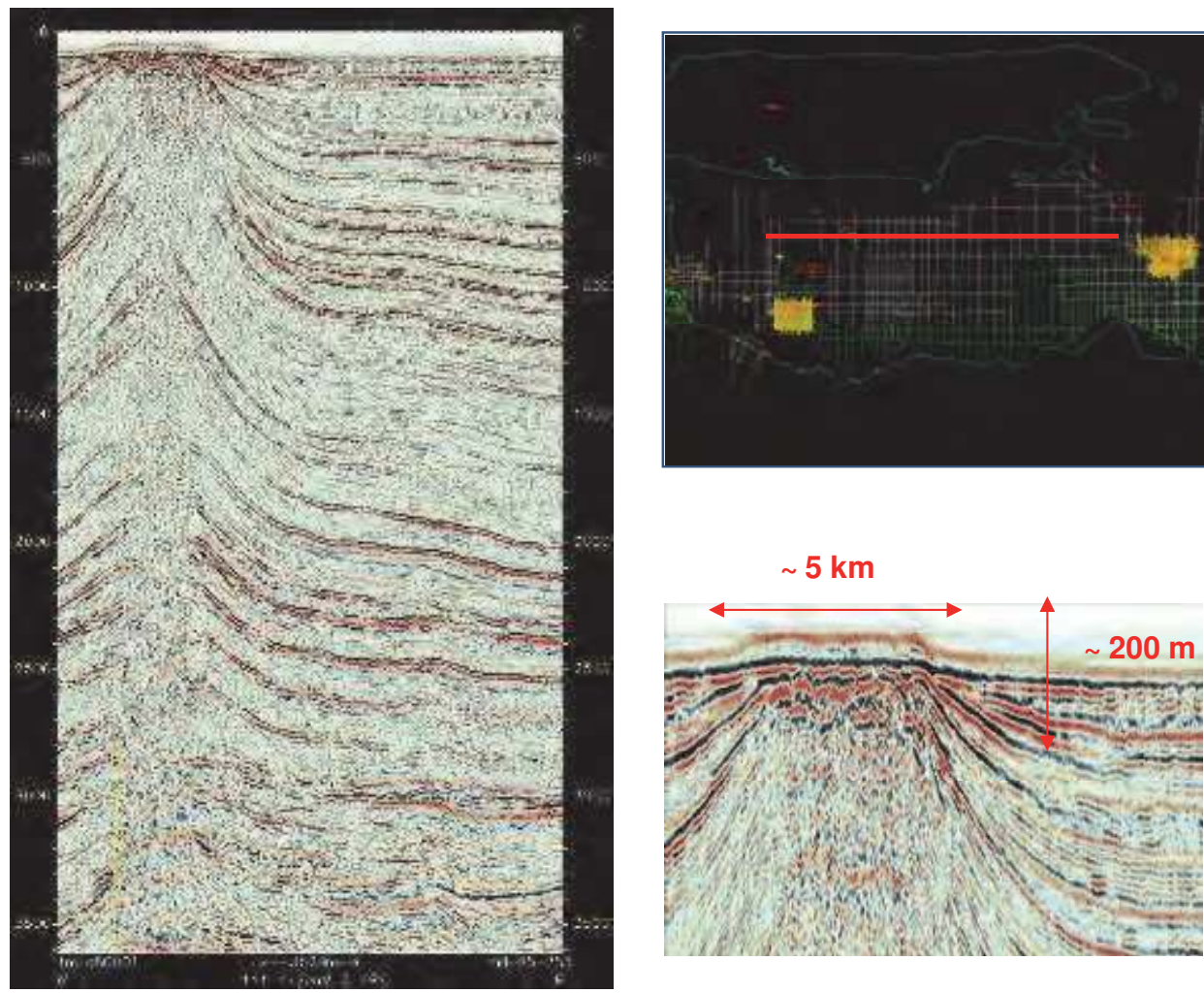

$\sim 5 \mathrm{~km}$

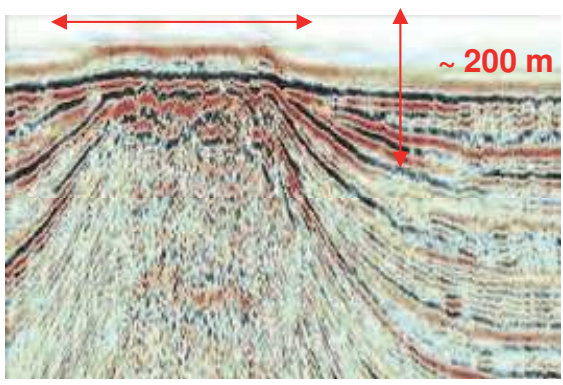

Fig. 43. Water Depth $\sim 40-50 \mathrm{~m}$ in the offshore Madura Strait

Stratigraphy of the Madura Strait started in Middle Eocene time by deposition of transgressive clastics unconformably on top of pre-Tertiary basement. The deposition was terminated by a local uplift at the end of Eocene time. Subsidence during the Oligocene resulted in deposition of deep marine sediments. An uplift at the end of the Oligocene resulted in a regional unconformity throughout the basin. During the Early Miocene time the rapid subsidence resulted in deposition of deep marine sediments in the area. In the mid-Late Miocene time, the basin was filled and another uplift took place. After a short subsidence to the end of Late Miocene, sedimentation interrupted again by an uplift in Early Pliocene time. The rapid subsidence in the late Pliocene time is characterized by the deposition of overpressured thick clays. The area subsided again into a shallow marine environment after the Plio-Pleistocene regional uplift (Widjonarko, 1990; Satyana and Asnidar, 2008).

\section{Conclusions}

- Mud diapir and mud volcano are piercement structures showing the release of overpressured sediments piercing upward from subsurface to the Earth's surface due to buoyancy and differential pressure. 
- The Kendeng-Madura Strait Zone is an ancient axial depression of Java to Madura Islands with elisional basin characteristics. The Mio-Pliocene and Pleistocene sediments were rapidly deposited into the depression and compressed as it was at the front of converging plate boundaries with high seismic activity. This resulted in numerous mud diapirs and mud volcanoes in the area. Sixteen mud volcanoes have so far been documented in East Java with the six mud volcanoes found along the Watukosek fault.

- LUSI, a new mud volcano, was born at the vicinity of the Watukosek fault. This geological phenomena as well as others occurring in the area such as the appearance of gas bubbles, cracks, subsidence, and vertical and horizontal displacement is believed to be due to a reactivation of existing faults in this area. The Watukosek fault system appeared to play a role in the existence of other six mud volcanoes at its vicinity.

- Early technical papers, such as Davies et al. (2007, 2008), Rubiandini et al. (2008) and Tingay et al. (2008) suggested a connection between the Banjarpanji-1 well and the mud volcano. These papers were based much on unverified and partial dataset. When the full dataset is integrated as in Sawolo et al. (2008, 2009 and 2010), it is evident that the well did not trigger LUSI mud volcano. Future analysis on the trigger of the mud volcano must consider this pitfall and integrate all available dataset. One must decipher and make use of the entire mud logger Real Time Data as it is the most reliable dataset, being automated, continuous and quantitative data that captures key operating parameters of the rig.

- The distance between the nearest volcanic complex, the Arjuno - Welirang volcanoes, to LUSI is about $10 \mathrm{~km}$. This close proximity may have influenced the geothermal properties of LUSI and affected its temperature and geochemistry.

- Studies suggest that LUSI is likely to continue to flow for many years to come. Better understanding of its plumbing system and detailed subsurface studies must be conducted as part of the hazard mitigation effort. The more than 16 East Java mud volcanoes in the vicinity must be used as an analogy of mud volcano processes and its morphology.

\section{Acknowledgement}

The Authors wishes to express appreciation to the management of MIGAS, BPMIGAS, EMP, Lapindo Brantas Inc for the permission to publish the paper. Constructive discussions and inputs from our colleagues in particular Peter Adam and Awang H. Satyana are also appreciated.

\section{References}

Abidin, H.Z., Davies, R.J., Kusuma, M.A., Andreas, H., Deguchi, T., 2008., Subsidence and uplift of Sidoarjo (East Java) due to the eruption of the LUSI mud volcano (2006 present). Environmental Geology doi:10.1007/s00254-008-1363-4.

Akhmanov, G.G. and Mazzini, A., 2007, Mud volcanism in elisional basin, In: Proceedings of the International Geological Workshop on Sidoarjo Mud Volcano, Jakarta, IAGIBPPT-LIPI, February 20-21, 2007. Indonesia Agency for the Assessment and Application of Technology, Jakarta. 
Amelung, F., Galloway, D.L., Bell, J.W., Zebker, H.A., Laczniak, R.J., 1999. Sensing the ups and downs of Las Vegas: InSAR reveals structural control of land subsidence and aquifer-system deformation. Geology 27 (6), 483-486.

Davies, R.J., Brumm, M., Manga, M., Rubiandini, R., Swarbrick, R., Tingay, M., 2008. The East Java mud volcano (2006 to present): an earthquake or drilling trigger? Earth and Planetary Science Letters 272 (3-4), 627-638.

Davies, R.J., Swarbrick, R.E., Evans, R.J. and Huuse, M., 2007, Birth of a mud volcano: East Java, 29 May 2006: GSA Today, v. 17, p. 4-9.

De Genevraye, P., Samuel, L., 1972. Geology of the Kendeng zone (Central and East Java). In: Proceedings of the Indonesian Petroleum Association, 1st Annual Convention, pp. 17-30.

Deguchi, T., Maruyama, Y., Kato, M., Kobayashi, C., 2007a. Surface displacement around mud volcano, East Java captured by Insar using Palsar data. In: Proceedings of the 28th Asian Conference on Remote Sensing.

Deguchi, T., Maruyama, Y., Kato, M., 2007b. Measurement of long-term deformation by InSAR using ALOS/PALSAR data. In: Presented at FRINGE 2007 workshop, November 2007, Frascati, Italy. Workshop presentation available from: http://earth.esa.int/workshops/fringe07/presentations.html Workshop proceedings are in press.

Desaunettes, J.R., 1977, Catalogue of Landsform for Indonesia, Trust Fund of The Goverment of Indonesia - FAO, Bogor.

Dimitrov, L.I., 2002. Mud volcanoes: the most important pathway for degassing deeply buried sediments. Earth Science Reviews 59 (1-4), 49-76.

Duyfjes, J., 1936, The geology and stratigraphy of the Kendeng area between Trinil and Surabaya (Java) (in German), De Mijningenieur, vol. 3, no. 8, August 1936, p. 136149.

Embry, AF, and Klovan, JE, 1971, A Late Devonian reef tract on Northeastern Banks Island, NWT: Canadian Petroleum Geology Bulletin, v. 19, p. 730-781.

Etiope, G., Feyzullayev, A., Milkov, A.V., Waseda, A., Mizobe, K., Sun, C.H., 2009, Evidence of subsurface anaerobic biodegradation of hydrocarbons and potential secondary methanogenesis in terrestrial mud volcanoes, Marine and Petroleum Geology 26 (2009) pp. 1692-1703

Fielding, E.J., Blom, R.G., Goldstein, R.M., 1998. Rapid subsidence over oil fields measured by SAR interferometry. Geophysical Research Letters 25 (17), 3215-3218.

Fukushima, Y., Cayol, V., Durand, P., 2005. Finding realistic dike models from interferometric synthetic aperture radar data: the February 2000 eruption at Piton de la Fournaise. Journal of Geophysical Research 110 B03206. doi:10.1029/ 2004JB003268.

Fukushima, Y., Mori, J., Hashimoto, M., Kano, Y., 2009. Subsidence associated with the LUSI mud eruption, East Java, investigated by SAR interferometry. Journal Marine and Petroleum Geology 26, 1740-1750.

Gourmelen, N., Amelung, F., Casu, F., Manzo, M., Lanari, R., 2007. Mining-related ground deformation in Crescent Valley, Nevada: implications for sparse GPS networks. Geophysical Research Letters 34 L09309. doi:10.1029/2007GL029427.

Guliyiev, I.S., Feizullayev, A.A., 1998. All About Mud Volcanoes. Nafta Press, Azerbaijan Publishing House, 52 pp. 
Hanssen, R.F., 2001. Radar Interferometry - Data Interpretation and Error Analysis. Kluwer Academic Publishers, Dordrecht, The Netherlands.

Higgins, G.E., Saunders, J.B., 1974. Mud volcanoes. Their nature and origin. Verhandlungen Naturforschenden Gesselschaft in Basel 84, 101-152.

Hochstein, M. P. and Sudarman, S., 2010, Monitoring of LUSI Mud-Volcano - a GeoPressured System, Java, Indonesia., Proceedings World Geothermal Congress 2010, Bali, Indonesia, 25-29 April 2010

Istadi, B., Pramono, G.H., Sumintadireja, P., Alam, S. Simulation on growth and potential Geohazard of East Java Mud Volcano, Indonesia. Marine \& Petroleum Geology, Mud volcano special issue, doi: 10.1016/j.marpetgeo.2009.03.006.

Istadi, B.P., Kadar, A., Sawolo, N., 2008. Analysis \& recent study results on East Java mud volcano. In: Subsurface Sediment Remobilization and Fluid Flow in Sedimentary Basin Conference, October 2008. The Geological Society, Burlington House, Piccadilly, London.

Kadar, A.P., Kadar, D., Aziz, F., 2007. Pleistocene stratigraphy of Banjarpanji\#1 well and the surrounding area. In: Proceedings of the International Geological Workshop on Sidoarjo Mud Volcano, Jakarta, IAGI-BPPT-LIPI, February 20-21, 2007. Indonesia Agency for the Assessment and Application of Technology, Jakarta.

Kholodov, V.N., 1983, Postsedimentary Transformations in Elisional Basins (example from Eastern Pre-Caucasus) (in Russian), 150 ps.

Koesoemadinata, R.P., 1980. Geologi Minyak dan Gas Bumi. 2 jilid, ed ke-2. Penerbit ITB, Bandung.

Kopf, A., 2002. Significance of mud volcanism. Reviews of Geophysics 40 (2), 1005, 2.1-2.52. doi:10.1029/2000RG000093

Kumai, H. and Yamamoto, H., 2007, Earthquake, the major trigger of Mud Volcanism at Sidoarjo, East Java., In: Proceedings of the International Geological Workshop on Sidoarjo Mud Volcano, Jakarta, IAGI-BPPT-LIPI, February 20-21, 2007. Indonesia Agency for the Assessment and Application of Technology, Jakarta.

Link, W.K., 1952. Significance of oil and gas seeps in world oil exploration. Am. Assoc. Pet. Geol. Bull. 36, 1505-1540.

Manga, M. and Brodsky, E. (2006): Seismic triggering of eruptions in the far field: Volcanoes and Geysers. Annual Review of Earth and Planetary Sciences, 34, 263-291.

Manga, M., 2007. Did an earthquake trigger the May 2006 eruption of the LUSI mud volcano? EOS 88 (201).

Manga, M., 2007. Did an earthquake trigger the may 2006 eruption of the LUSI mud volcano? EOS 88 (18), 201.

Manga, M., Rudolph, M.L., Brumm, M., 2009. Earthquake triggering of mud volcanoes: a review 26, 1785-1798.

Massonnet, D., Feigl, K.L., 1998. Radar interferometry and its application to changes in the Earth's surface. Review of Geophysics 36, 441-500.

Mazzini, A., Nermoen, A., Krotkiewski, M., Podladchikov, Y.Y., Planke, S., Svensen, H., 2009. Strike-slip faulting as a trigger mechanism for overpressure release through piercement structures. Implications for the LUSI mud volcano, Indonesia. Marine and Petroleum Geology 26, 1751-1765. 
Mazzini, A., Svensen, H., Akhmanov, G.G., Aloisi, G. Planke, S., Malthe-Serenssen, A and Istadi. B., 2007, Trigering and dynamic evolution of LUSI mud volcano, Indonesia: Earth and Planetary Sciences Letters, v. 261, p. 375-388.

Mellors, R., Kilb, D., Aliyev, A., Glasanov, A. and Yetirmishli, G. (2007): Correlations between earthquakes and large mud volcano eruptions. Journal of Geophysical Research, 112, doi:10.1029/2006JB004489.

Milkov, A.V., 2000, Worldwide distribution of submarine mud volcanoes and associated gas hydrates, Marine Geology, 167, p. 29-42.

Milkov, A.V., 2005. Global distribution of mud volcanoes and their significance in petroleum exploration, as a source of methane in the atmosphere and hydrosphere, and as geohazard. In: Martinelli, G., Panahi, B. (Eds.), Mud Volcanoes, Geodynamics and Seismicity. NATO Science Series, IV Earth and Environmental Sciences, vol. 51, Springer, pp. 29-34.

Mori, J. and Kano, Y., 2009, Is the 2006 Yogyakarta Earthquake Related to the Triggering of the Sidoarjo, Indonesia Mud Volcano? Journal of Geography 118 (3)492-498 2009

Nawangsidi, D., 2007. In search of theory on flow mechanism of wild mud blow. In: Proceedings of the International Geological Workshop on Sidoarjo Mud Volcano, Jakarta, IAGI-BPPT-LIPI, February 20-21, 2007, Indonesia Agency for the Assessment and Application of Technology, Jakarta.

Pitt, A.M., Hutchinson, R.A., 1982. Hydrothermal changes related to earthquake activity at mud volcano, Yellowstone National Park, Wyoming. Journal of Geophysical Research 87, 2762-2766.

Satyana, A.H. and Armandita, C., 2004, Deep-Water play of Java, Indonesia : regional evaluation on opportunities and risks, Proccedings International Geoscience Conference of Deepwater and Frontier Exploration in Asia and Australasia, Indonesian Petroleum Association (IPA) and American Association of Petroleum Geologists (AAPG), Jakarta, p. 293-320.

Satyana, A.H. and Asnidar, 2008, Mud Diapirs and Mud Volcanoes of Java to Madura: Origins, Natures, and Implications to Petroleum System, Proceedings Indonesian Petroleum Association (IPA), 32nd annual convention, Jakarta, 27-29 May 2008.

Satyana, A.H., 2007, Bencana Geologi dalam "Sandhyâkâla" Jenggala dan Majapahit : Hipotesis Erupsi Gununglumpur Historis Berdasarkan Kitab Pararaton, Serat Kanda, Babad Tanah Jawi; Folklor Timun Mas; Analogi Erupsi LUSI; dan Analisis Geologi Depresi Kendeng-Delta Brantas, Proceedings Joint Convention Bali 2007HAGI, IAGI, and IATMI, 14-16 November 2007.

Satyana, A.H., 2008, Roles of Mud Volcanoes Eruptions in the Decline of the Jenggala and Majapahit Empires, East Java, Indonesia: Constraints from the Historical Chronicles, Folklore, and Geological Analysis of the Brantas Delta-Kendeng Depression, Majalah Geologi Indonesia, vol. 23, no. 1-2, p. 1-10.

Sawolo, N., Sutriono, E., Istadi, B.P., Darmoyo, A.B., 2008. East Java mud volcano (LUSI): drilling facts and analysis. In: Proceedings of the African Energy Global Impact, AAPG International Conference and Exhibition, October 2008, Cape Town, South Africa.

Sawolo, N., Sutriono, E., Istadi, B.P., Darmoyo, A.B., 2009. Mud volcano triggering controversy: was it caused by drilling? Journal Marine and Petroleum Geology 26, (2009) 1766-1784. doi:10.1016/j.marpetgeo.2009.04.002 
Sawolo, N., Sutriono, E., Istadi, B.P., Darmoyo, A.B., 2010. Was LUSI caused by drilling? Authors reply to discussion. Journal Marine and Petroleum Geology 27 (2010) 1658-1675. doi:10.1016/j.marpetgeo.2010.01.018

Schiller, D.M., Seubert, B.W., Musliki, S., Abdullah, M., 1994, The reservoir potential of globigerinid sands in Indonesia, Indon. Petroleum Assoc. 23nd Ann. Conv.

Sharaf, E.F., BouDagher-Fadel, M.K., Simo, J.A. (Toni) and Caroll, A.R., 2005, Biostratigraphy and strontium isotope dating of Oligocene-Miocene strata, East java, Indonesia., Stratigraphy, vol. 2, no. 3, pp. 1-19, text figure 1-4, tables 1, plate 15.

Sudarman and Hendrasto, 2007, Hot Mud Flow At Sidoarjo., In: Proceedings of the International Geological Workshop on Sidoarjo Mud Volcano, Jakarta, IAGI-BPPTLIPI, February 20-21, 2007. Indonesia Agency for the Assessment and Application of Technology, Jakarta.

Sukarna, D., 2007, Mud Volcano In Indonesia: Distribution and its geological Phenomenon., In: Proceedings of the International Geological Workshop on Sidoarjo Mud Volcano, Jakarta, IAGI-BPPT-LIPI, February 20-21, 2007. Indonesia Agency for the Assessment and Application of Technology, Jakarta.

Sumintadireja, P., Purwaman, I., Istadi, B., Darmoyo, A.B., 2007. Geology and geophysics study in revealing subsurface condition of Banjarpanji mud extrusion, Sidoarjo, East Java, Indonesia. In: Proceedings of the International Union of Geodesy and Geophysics (IUGG) XXIV, Perugia, Italy.

Sunardi, E., Guntoro, A., Alam, S., Koesoema, M.A., Hadi, S., Budiman, A., 2007. Studi Geologi Dan Geofisika Semburan Lumpur Di Daerah Porong Sidoarjo, Jawa Timur., In: Proceedings of the International Geological Workshop on Sidoarjo Mud Volcano, Jakarta, IAGI-BPPT-LIPI, February 20-21, 2007. Indonesia Agency for the Assessment and Application of Technology, Jakarta.

Sutaningsih, N.E., Humaida, H., Zaennudin, A., Suryono, Primulyana, S., 2010. Indikasi Sistim Geotermal Pada Semburan Lumpur Sidoarjo Ditinjau Dari Karakteristik Kimia, Proceedings PIT IAGI Lombok 2010, The 39th IAGI Annual Convention and Exhibition

Tingay, M.R.P., Heidbach, O., Davies, R., Swarbrick, R., 2008. Triggering of the LUSI Mud Eruption: Earthquake Versus Drilling Initiation. Geology, vol. 36(8), pp. 639-642.

Tingay, M.R.P., 2010. Anatomy of the Lusi Mud Eruption, East Java. Australian Society of Exploration Geophysicists 21st International Conference and Exhibition, 23-26 August 2010, Sydney, Australia, doi:10.1071/ ASEG2010ab241.

Walter, T.R., Wang, R., Luehr, B.G., Wassermann, J., Behr, Y., Parolai, S., Anggraini, A., Günther, E., Sobiesiak, M., Grosser, H., Wetzel, H.U., Milkereit, C., Sri Brotopuspito, P.J.K., Harjadi, P., Zschau, J., The 26 May 2006 magnitude 6.4 Yogyakarta earthquake south of Mt. Merapi volcano: did lahar deposits amplify ground shaking and thus lead to the disaster?. G-cubed: Geochemistry Geophysics Geosystems, 9, Q05006, doi: 10.1029/2007GC001810.

Watanabe, N., dan Kadar, D., 1985, Quaternary Geology of the Hominids Fósil Bearing Formations in Java : Report of the Indonesia - Japan Research Project, CTA - 41, 1976 - 1979, Geological Research and Development Centre Special Publication, Bandung,P. 378 
Widjonarko, R., 1990, BD field - a case history, Proceedings Indonesian Petroleum Association (IPA), 19th Annu. Conv., p. 161-182.

Willumsen, P., Schiller, D.M., 1994. High quality volcaniclastic sandstone reservoirs in East Java, Indonesia. In: 23rd Annual Convention, vol. I. IPA, pp. 101-111. 


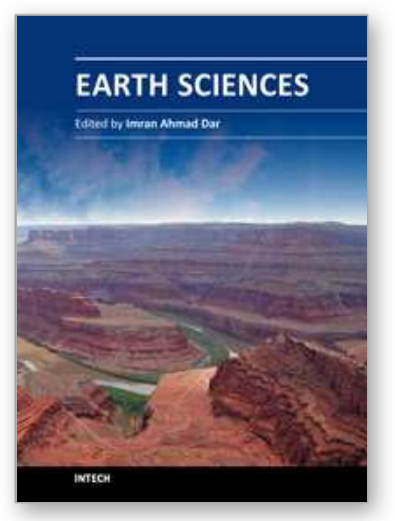

\author{
Earth Sciences \\ Edited by Dr. Imran Ahmad Dar
}

ISBN 978-953-307-861-8

Hard cover, 648 pages

Publisher InTech

Published online 03, February, 2012

Published in print edition February, 2012

The studies of Earth's history and of the physical and chemical properties of the substances that make up our planet, are of great significance to our understanding both of its past and its future. The geological and other environmental processes on Earth and the composition of the planet are of vital importance in locating and harnessing its resources. This book is primarily written for research scholars, geologists, civil engineers, mining engineers, and environmentalists. Hopefully the text will be used by students, and it will continue to be of value to them throughout their subsequent professional and research careers. This does not mean to infer that the book was written solely or mainly with the student in mind. Indeed from the point of view of the researcher in Earth and Environmental Science it could be argued that this text contains more detail than he will require in his initial studies or research.

\title{
How to reference
}

In order to correctly reference this scholarly work, feel free to copy and paste the following:

Bambang P. Istadi, Handoko T. Wibowo, Edy Sunardi, Soffian Hadi and Nurrochmat Sawolo (2012). Mud Volcano and Its Evolution, Earth Sciences, Dr. Imran Ahmad Dar (Ed.), ISBN: 978-953-307-861-8, InTech, Available from: http://www.intechopen.com/books/earth-sciences/mud-volcano-and-its-evolution

\section{INTECH}

open science | open minds

\section{InTech Europe}

University Campus STeP Ri

Slavka Krautzeka 83/A

51000 Rijeka, Croatia

Phone: +385 (51) 770447

Fax: +385 (51) 686166

www.intechopen.com

\section{InTech China}

Unit 405, Office Block, Hotel Equatorial Shanghai

No.65, Yan An Road (West), Shanghai, 200040, China 中国上海市延安西路65号上海国际贵都大饭店办公楼 405 单元

Phone: +86-21-62489820

Fax: +86-21-62489821 
(C) 2012 The Author(s). Licensee IntechOpen. This is an open access article distributed under the terms of the Creative Commons Attribution 3.0 License, which permits unrestricted use, distribution, and reproduction in any medium, provided the original work is properly cited. 